\title{
Potential for Energy Conservation in the Cement Industry
}

\author{
B. A. Garrett-Price
}

February 1985

Prepared for the U.S. Department of Energy under Contract DE-AC06-76RLO 1830

Pacific Northwest Laboratory

Operated for the U.S. Department of Energy by Battelle Memorial Institute

พั้ Battelle 


\title{
DISCLAIMER
}

This report was prepared as an account of work sponsored by an agency of the United States Government. Neither the United States Government nor any agency thereof, nor any of their employees, makes any warranty, express or implied, or assumes any legal liability or responsibility for the accuracy, completeness, or usefulness of any information, apparatus, product, or process disclosed, or represents that its use would not infringe privately owned rights. Reference herein to any specific commercial product, process, or service by trade name, trademark, manufacturer, or otherwise, does not necessarily constitute or imply its endorsement, recommendation, or favoring by the United States Government or any agency thereof. The views and opinions of authors expressed herein do not necessarily state or reflect those of the United States Government or any agency thereof.

\author{
PACIFIC NORTHWEST LABORATORY \\ operated by \\ BATTELLE \\ for the \\ UNITED STATES DEPARTMENT OF ENERGY \\ under Contract DE-AC06-76RLO 1830
}

\begin{tabular}{|c|c|}
\hline \multirow{2}{*}{\multicolumn{2}{|c|}{ Printed in the United States of America }} \\
\hline & \\
\hline \multicolumn{2}{|c|}{$\begin{array}{l}\text { Available from } \\
\text { National Technical Information Service }\end{array}$} \\
\hline \multirow{3}{*}{\multicolumn{2}{|c|}{$\begin{array}{c}\text { National Technical Information Service } \\
\text { United States Department of Commerce } \\
5285 \text { Port Royal Road } \\
\text { Springfield, Virginia } 22161\end{array}$}} \\
\hline & \\
\hline & \\
\hline \multirow{2}{*}{\multicolumn{2}{|c|}{$\begin{array}{l}\text { NTIS Price Codes } \\
\text { Microfiche A01 }\end{array}$}} \\
\hline & \\
\hline \multicolumn{2}{|c|}{ Printed Copy } \\
\hline & \\
\hline Pages & Codes \\
\hline $001-025$ & A02 \\
\hline $026-050$ & $\mathrm{~A} 03$ \\
\hline $051-075$ & A04 \\
\hline $076-100$ & A05 \\
\hline $101-125$ & A06 \\
\hline $126-150$ & A07 \\
\hline $151-175$ & $\mathrm{~A} 0 \mathrm{~B}$ \\
\hline $176-200$ & A09 \\
\hline $201-225$ & A010 \\
\hline $226-250$ & A011 \\
\hline $251-275$ & A012 \\
\hline $276-300$ & $A 013$ \\
\hline
\end{tabular}


POTENTIAL FOR ENERGY CONSERVATION IN THE CEMENT INDUSTRY

B. A. Garrett-Price

February 1985

Prepared for the U.S. Department of Energy under Contract DE-AC06-76RLO 1830

Pacific Northwest Laboratory Richland, Washington 99352 


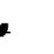

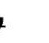

. 


\section{ABSTRACT}

This report assesses the potential for energy conservation in the cement industry. Energy consumption per ton of cement decreased 20\% between 1972 and 1982. During this same period, the cement industry became heavily dependent on coal and coke as its primary fuel source. Although the energy consumed per ton of cement has declined markedly in the past ten years, the industry still uses more than three and a half times the fuel that is theoretically required to produce a ton of clinker. Improving kiln thermal efficiency offers the greatest opportunity for saving fuel. Improving the efficiency of finish grinding offers the greatest potential for reducing electricity use. Technologies are currently available to the cement industry to reduce its average fuel consumption per ton of product by as much as $40 \%$ and its electricity consumption per ton by about $10 \%$. The major impediment to adopting these technologies is the cement industry's lack of capital as a result of low or no profits in recent years. 


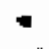

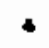
. 


\section{ACKNOWLEDGMENTS}

The author gratefully acknowledges the guidance and thorough reviews provided by the following:

- John Rossmeiss1, Tom Gross, Jerry Collins and Ralph Sheneman, U.S. Department of Energy, Office of Industrial Programs

- Stuart Tresouthick and Muhammad Bhatty, Portland Cement Association

- Thomas Brown, Allis-Chalmers Corporation

- Gordon Fisher, Polysius Corporation

- Ken Hitcho, Humboldt Wedag

- Bill Fleming and Russ McMann, Gifford-Hill \& Company

- A. 'N. Mees and Randy Bergman, Ideal Basic Industries

- Richard Cooke, Ash Grove Cement

- Bryant Mather and AI Buck, U.S. Army Waterways Experiment Station

In addition, I would like to thank Vicki Lee for editing and coordinating publication. 



\section{SUMMARY}

The Office of Industrial Programs (OIP) within the U.S. Department of Energy (DOE) contracted Pacific Northwest Laboratory (PNL) to assess the energy conservation potential in six industries. Those six industries are as follows:

- Aluminum

- Cement

- Glass
- Pulp and Paper

- Stee1

- Textiles

This data will enable OIP to evaluate R\&D opportunities that reflect the current energy and economic environments in which various industries operate.

The purpose of this report is to assess the potential for energy conservation in the cement industry and to identify the critical research and development ( $R \& D$ ) areas that must be addressed to advance the industry's adoption of energy-conserving technologies.

Energy use in the cement industry has undergone significant changes during the ten-year period from 1972 to 1982. Energy consumption per ton of product declined $20 \%$, and the industry shifted from natural gas and petroleum products to coal as its primary fuel. Currently, coke and coal account for about $88 \%$ of the fuel used by the cement industry, whereas ten years ago these fuels accounted for less than $40 \%$.

Despite its reduction in energy use, the industry still uses about three and a half times the fuel that is theoretically required to produce a ton of clinker. (a) Changing from the wet to the dry process and adoption of preheaters and precalciners on dry process kilns have accounted for most of the reductions in energy use. In 1982, the difference between the theoretical fuel requirement and the fuel actually used was more than 200 trillion Btu. Figure S.1 shows the differences between the theoretical fuel requirement and 1) the industry-average fuel use, 2) the average fuel use of each of the

(a) Partially fused product from the kiln. 


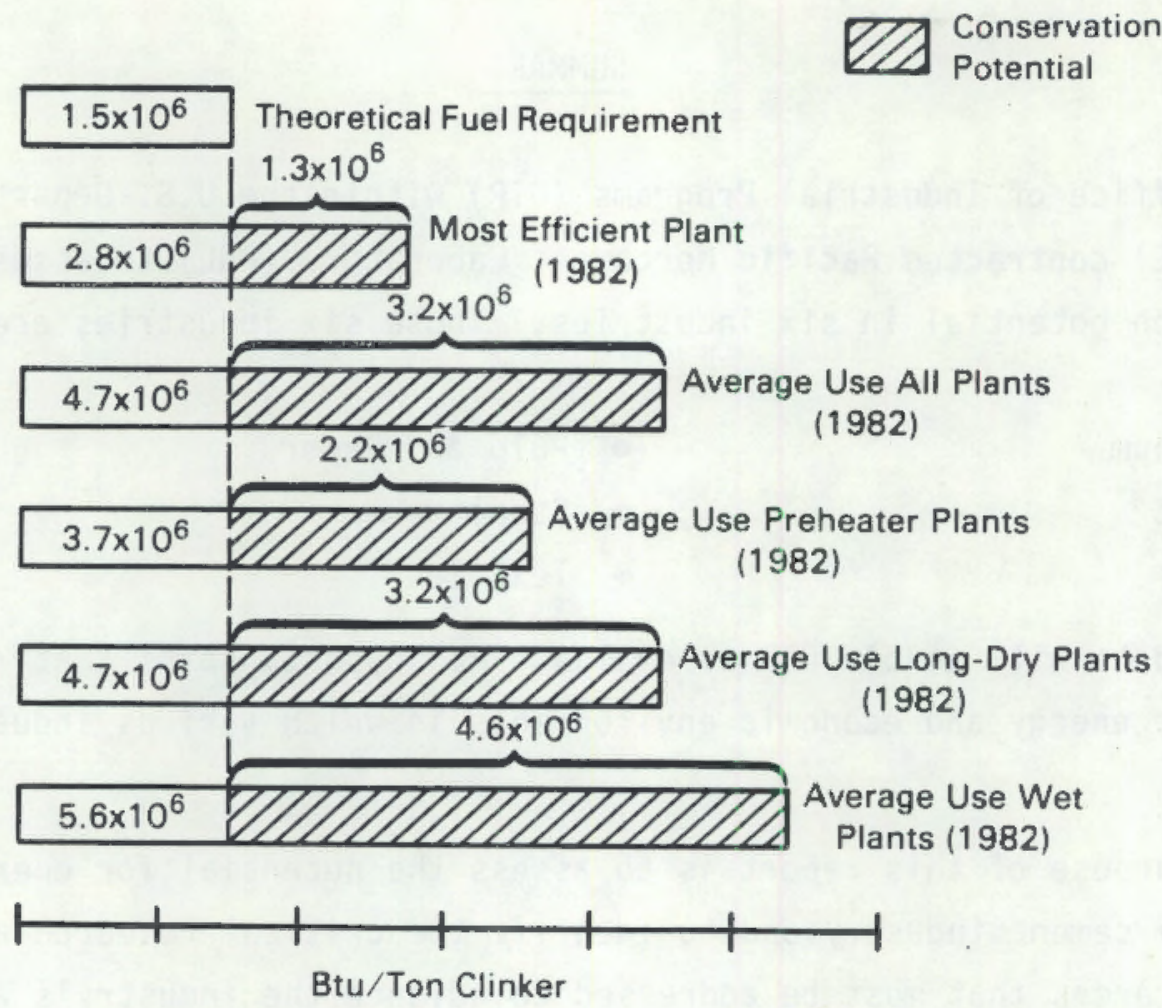

FIGURE S.1. Differences Between the Theoretical and Actual Fuel Use in the Cement Industry

three major types of processes, and 3) the fuel use of the most efficient plant. In each case, the gap between actual use and theoretical use represents the fuel savings potential.

Current technologies are available which could reduce the average fuel consumption of the cement industry per ton of product by as much as $40 \%$ and the average electricity consumption by about $10 \%$. The major barrier to the adoption of these technologies is the cement industry's lack of investment capital.

A number of currently available and advanced energy-saving technologies applicable to the cement industry are identified in Table S.1. Estimates of the energy savings that may be realized by adopting those technologies are also summarized in the table. Savings estimates are based on 1982 production levels and are relative to 1982 energy-use figures. That is, the savings estimates represent the difference between the energy requirements with the new technology implemented and the actual 1982 energy use. Appendix D discusses the methodology used to calculate energy savings in more detail. Savings estimates 
TABLE S.1. Estimates of the Fnergy-Savings Potential of Current and Advanced Technologies Relative to 1982 Base Year

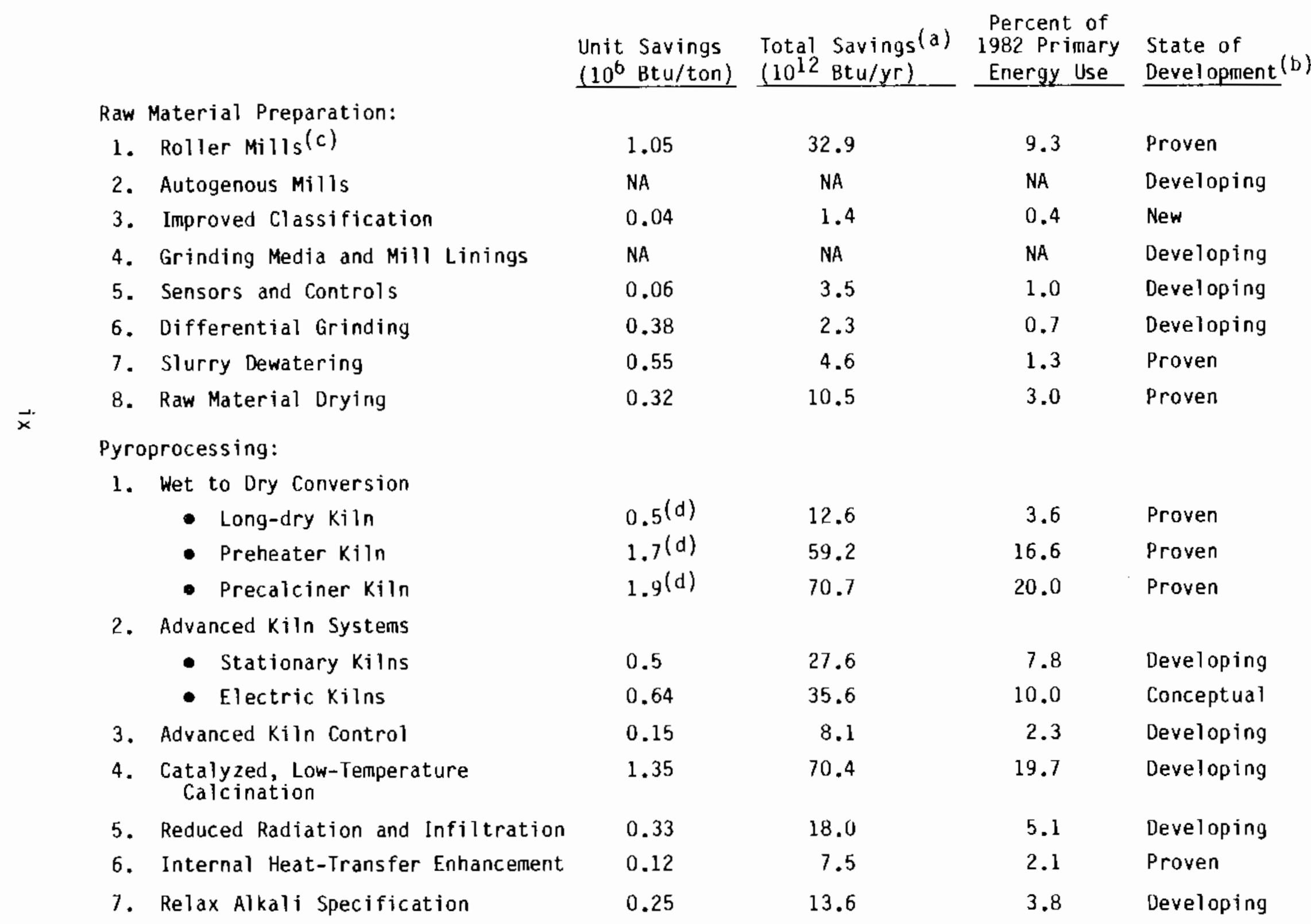


TABLE S.1. (cont d)

Finish Grinding:

\begin{tabular}{lll} 
Unit Savings & Total Savings (a) & $\begin{array}{c}\text { Percent of } \\
1982 \text { Primary State of } \\
\left(10^{6} \text { Btu/ton }\right)\end{array}$ \\
\hline
\end{tabular}

1. Roller Mills

0.06

3.9

1.1

New

2. Roller Press

0.16

8.6

2.4

Developing

3. Cone Crusher

NA

NA

NA

Developing

4. Improved Classification

0.09

5.4

1.5

New

5. Grinding Aids

NA

NA

NA

Proven

6. Grinding Media and Mill Linings

NA

NA

NA

Developing

7. Sensors and Controls

0.18

10.2

2.9

Developing

8. Modify Fineness Specification

0.18

10.2

2.9

Proven

Waste Materials Utilization:

1. Blended Cements (e)

1.1

60.0

16.9

Developing

2. Refuse-Derived Fuels (f)

0.98

12.6

Developing

Waste Heat Utilization:

1. Steam Rankine Bottoming

2. Organic Rankine Bottoming

$0.15 \quad B .6$

\subsection{Proven}

0.18

10.2

$2.9 \quad$ Developing

(a) Based on 1982 production levels. Technologies which reduce power consumption are given in terms of the primary fuel savings at the utility (i.e., $1 \mathrm{kWh}=10,500 \mathrm{Btu}$ ).

(b) Proven = fully commercialized; New = demonstrated, but are not yet widely used; Developing = under active investigation; Conceptual = articulated, but not yet under active investigation.

(c) Includes both electricity savings and savings due to waste heat utilization for drying.

(d) Savings relative to the wet process.

(e) Based on $20 \%$ substitution of a waste material for cement.

(f) Based on $20 \%$ substitution of a waste material for conventional fuel.

NA Not Available. 
for technologies that reduce power consumption are given in terms of the primary fuel used at the central-station utility.

Improving the thermal efficiency of kilns and increasing the production and use of blended cements have the greatest near-term potentials for reducing the fuel consumption of the cement industry. In addition, the use of wastederived fuels offers the opportunity to displace high-grade conventional fuels.

Although electricity accounts for only about $9 \%$ of the direct energy input to cement-making operations, the cost of electricity accounts for more than one-third of the industry's annual energy costs. Therefore, although most of the industry's energy conservation efforts to date have focused on fuel use, the rapid escalation of electricity costs relative to fuel costs is shifting the focus to reducing power consumption.

Improving the efficiency of crushing and grinding equipment and using waste heat to generate electricity are becoming particularly important as the price of electricity continues to escalate sharply relative to fuel prices.

Research and development (R\&D) related to conserving energy in cementnaking operations are conducted primarily by 1) the Portland Cement Association (PCA), $2 i$ the DOE, and 3) domestic and foreign suppliers of equipment to the cement industry. In addition, some U.S. cement companies perform in-house projects. It is much more common for cement companies to engage in R\&D activities in Japan and Europe, often in association with an equipment nanufacturer. Table S.2 summarizes the types of conservation-related research activities recently completed or currently being pursued by PCA, DOE or the private sector.

A list of R\&D opportunities was compiled through an iterative review by cement industry personnel. R\&D areas thought to have the potential to reduce energy consumption in the cement industry through improvements to existing technologies or through the development of new technologies are listed in rable S.3. 
TABLE S.2. Conservation-Related Research and Development Activities

\section{U.S. Department of Energy}

- Laboratory and field studies of kiln dust and coal fly ash blends (jointly funded with the Department of Transportation and performed by Valley Forge Laboratories, Inc., Devon, Pennsylvania)

- Laboratory studies of catalyzed, low-temperature calcination (performed by Southwest Research Institute, San Antonio, Texas)

- Study of wear and corrosion of grinding media in ball mills (University of Minnesota)

- Mathematical modeling of two-stage classification (Amax Extractive R\&D)

- Study of improved grinding machines (Rexnord)

- Investigation of high-tensile cement pastes (PCA)

- Investigation of particle size control in cement (PCA)

Portland Cement Association

- Extension of My ash technology as it applies to concrete

- Use of high-sulfur fuels in pyroprocessing of portland cement clinker

- Use of carbonate addition to portland cement for grinding energy conservation and cement property improvement

- Use of cement kiln dust in blended cements and other applications

- Use of concrete products in passive solar building systems and energy conservation in buildings

- Neutron activation analysis of raw materials

- Raw grinding optimization

\section{Private-Sector}

- Preheater/precalciner technology

- Low-pressure drop cyclones for preheaters

- High-efficiency air classification equipment

- Energy-efficient finish grinding mills (roller mills, cone crushers, high-pressure roller presses)

- Automatic kiln control systems

- Fluid-bed furnaces for feed material drying

- Advanced stationary kilns 
TABLE S.3. Potential R\&D Opportunities for Saving Energy

in the Cement Industry

Kiln Thermal Efficiency Improvements

- Develop instruments for on-line analyses

- Develop means to mitigate shell heat losses

Potential(a)

Energy Savings

- Develop improved kiln feed homogenization system

- Develop advanced pyroprocessing concepts

Improved Crushing and Grinding

- Technology Transfer

Waste Material Utilization

Blended Cements:

$30-90$ (b)

- Characterize fly ash and hydration mechanisms

- Establish performance data for a variety of dusts, cements, fly ashes and slags in mortars and concretes

- Perform case studies of the economic feasibility of using waste materials in concrete preparation

- Investigate possible changes to ASTM and NBS cement specifications and standards

Waste-Derived Fuels:

- Investigate the impact of various wastes on product quality, process control, and pollution control

Waste Heat Utilization

- Develop high-temperature filters for particle-laden gases

- Investigate build-up problems in heat-recovery equipment

Process/2roduct Development

- Investigate optimal raw mixes with respect to cement quality requi rements

- Investigate performance specifications to replace prescriptive specifications

- Develop high-tensile cements

- Further investigate catalyzed, low-temperature calination

(a) Based on 1982 production levels.

(b) Range represents from $10 \%$ to $30 \%$ substitution of waste material.

(c) Savings in higher-grade fuel resulting from $10 \%$ to $30 \%$ substitution of waste.

(d) Savings depend on energy content of the construction material replaced by high-tensile cement. 
CONTENTS

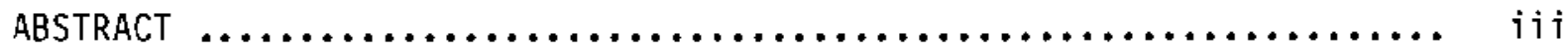

ACKNOWLEDGMENTS $\ldots \ldots \ldots \ldots \ldots \ldots \ldots \ldots \ldots \ldots \ldots \ldots \ldots \ldots \ldots \ldots \ldots$

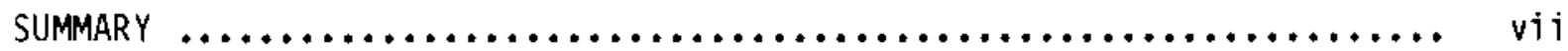

1.0 INTROOUCTION $\ldots \ldots \ldots \ldots \ldots \ldots \ldots \ldots \ldots \ldots \ldots \ldots \ldots \ldots \ldots \ldots \ldots \ldots \ldots \ldots \ldots$

2.0 CEMENT INOUSTRY ENERGY USE $\ldots \ldots \ldots \ldots \ldots \ldots \ldots \ldots \ldots \ldots \ldots \ldots \ldots \ldots \ldots \ldots \ldots \ldots$

2.1 BASELINE ENERGY PROFILE $\ldots \ldots \ldots \ldots \ldots \ldots \ldots \ldots \ldots \ldots \ldots \ldots \ldots \ldots \ldots \ldots$

$2.1 .1 \quad 1982$ Economic Climate ..................... 2.2

2.1 .2 Base-Year Energy Use $\ldots \ldots \ldots \ldots \ldots \ldots \ldots \ldots \ldots \ldots \ldots \ldots . . \ldots \ldots$

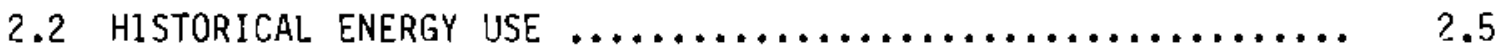

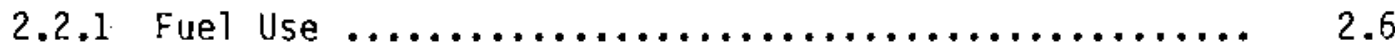

2.2.2 Electricity Use $\ldots \ldots \ldots \ldots \ldots \ldots \ldots \ldots \ldots \ldots \ldots \ldots \ldots . . \ldots . . \ldots$

2.2.3 Conservation Trends ....................... 2.9

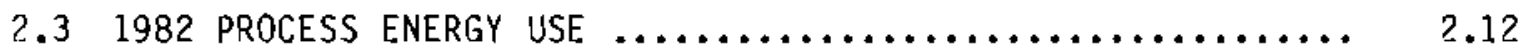

2.3.1 Raw Materials Preparation .................. 2.12

2.3 .2 Pyroprocessing $\ldots \ldots \ldots \ldots \ldots \ldots \ldots \ldots \ldots \ldots \ldots \ldots \ldots \ldots$

2.3 .3 Finish Grinding $\ldots \ldots \ldots \ldots \ldots \ldots \ldots \ldots \ldots \ldots \ldots \ldots \ldots .2 .17$

2.3 .4 Summary of Process Energy Use $\ldots \ldots \ldots \ldots \ldots \ldots \ldots \ldots \ldots$

3.0 RAW MATERIAL PREPARATION $\ldots \ldots \ldots \ldots \ldots \ldots \ldots \ldots \ldots \ldots \ldots \ldots \ldots \ldots \ldots \ldots \ldots \ldots$

3.1 CRUSHING ANO GRINDING IMPROVEMENTS $\ldots \ldots \ldots \ldots \ldots \ldots \ldots \ldots \ldots . . \ldots \ldots$

3.1 .1 Roller Mills $\ldots \ldots \ldots \ldots \ldots \ldots \ldots \ldots \ldots \ldots \ldots \ldots \ldots \ldots . . \ldots .2$

3.1 .2 Autogenous Mills $\ldots \ldots \ldots \ldots \ldots \ldots \ldots \ldots \ldots \ldots \ldots \ldots \ldots . \ldots \ldots$

3.1 .3 Improved Classification $\ldots \ldots \ldots \ldots \ldots \ldots \ldots \ldots \ldots . \ldots \ldots$

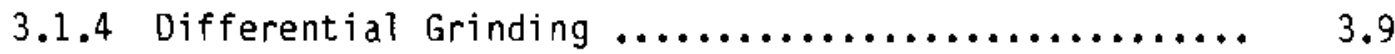

3.1.5 Grinding Media and Mi11 Lining ............... 3.11 


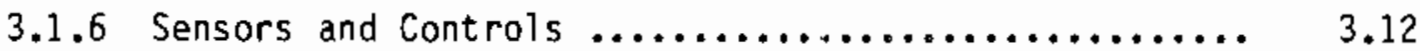

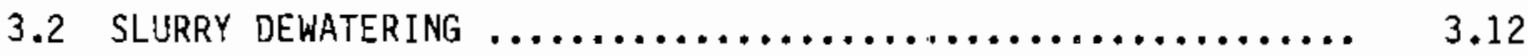

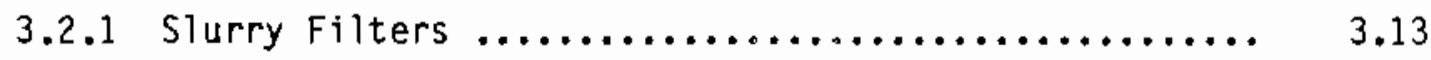

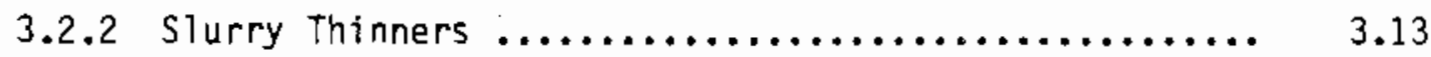

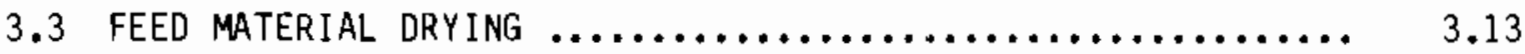

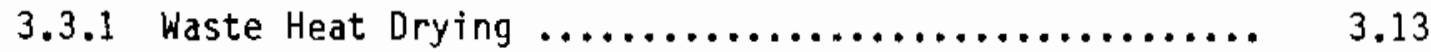

3.3.2 Fluidized-Bed Drying ........................ 3.14

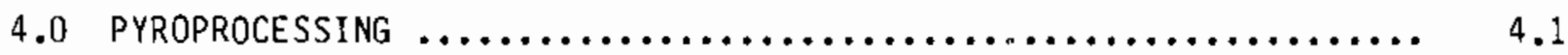

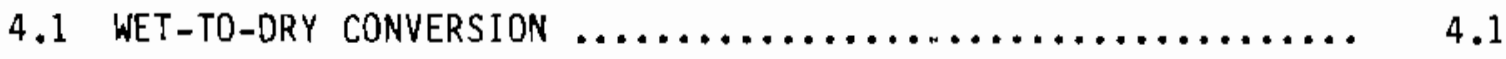

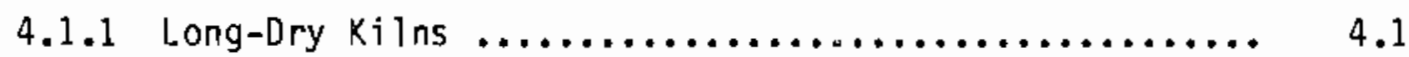

4.1 .2 Preheater Kilns $\ldots \ldots \ldots \ldots \ldots \ldots \ldots \ldots \ldots \ldots \ldots, \quad 4.2$

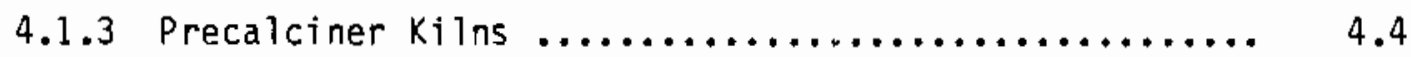

4.1.4 Energy-Savings Potential $\ldots \ldots \ldots \ldots \ldots \ldots \ldots \ldots \ldots, 4.7$

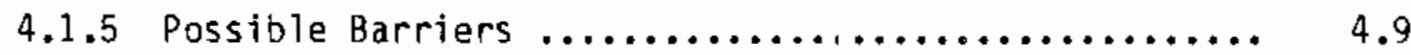

4.1.6 Economics of Kiln Conversion ................... 4.10

4.2 AdVANCEO KILn SYSTEMS $\ldots \ldots \ldots \ldots \ldots \ldots \ldots \ldots \ldots \ldots \ldots \ldots \ldots, 4.10$

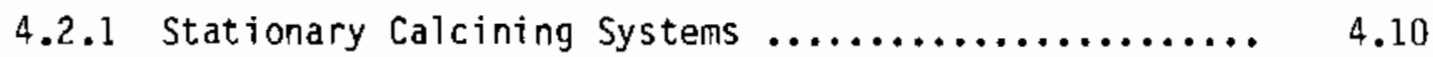

4.2 .2 All-Electric Kilns ......................... 4.16

4.3 ADVANCED KILN CONTROL $\ldots \ldots \ldots \ldots \ldots \ldots \ldots \ldots \ldots \ldots \ldots \ldots \ldots, 4.18$

4.3.1 Energy-Savings Potential .................... 4.19

4.3.2 Possible Barriers ............................ 4.20

4.4 CATALyzed, LOW-TEMPERATURE CALCination PROCESS $\ldots \ldots \ldots \ldots \ldots .4 .20$

4.4.1 Energy-Saving Potential $\ldots \ldots \ldots \ldots \ldots \ldots \ldots \ldots \ldots . ., 4.20$

4.4.2 Possible Barriers .......................... $\quad 4.20$

4.5 KILN RADIATION AND INFILTRATION LOSSES $\ldots \ldots \ldots \ldots \ldots \ldots \ldots ., 4.20$ 
4.5.1 Energy-Savings Potential $\ldots \ldots \ldots \ldots \ldots \ldots \ldots \ldots \ldots . .6 .21$

4.6 INTERNAL HEAT-TRANSFER-ENHANCEMENT DEVICES $\ldots \ldots \ldots \ldots \ldots \ldots, 4.21$

4.6 .1 Chains $\ldots \ldots \ldots \ldots \ldots \ldots \ldots \ldots \ldots \ldots \ldots \ldots \ldots \ldots, 4.21$

4.6 .2 Trefoils $\ldots \ldots \ldots \ldots \ldots \ldots \ldots \ldots \ldots \ldots \ldots \ldots \ldots \ldots, 4.22$

4.6 .3 Lifters or Ledges $\ldots \ldots \ldots \ldots \ldots \ldots \ldots \ldots \ldots \ldots \ldots \ldots, 4.22$

4.6.4 Energy-Savings Potential $\ldots \ldots \ldots \ldots \ldots \ldots \ldots \ldots \ldots, 4.22$

4.6.5 Possible Barriers ............................ 4.23

4.7 ALKALI SPECIFICATION MOORICATION $\ldots \ldots \ldots \ldots \ldots \ldots \ldots \ldots \ldots, 4.23$

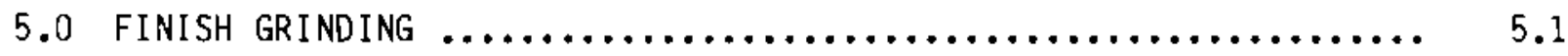

5.1 Alternative grinding EquipMent $\ldots \ldots \ldots \ldots \ldots \ldots \ldots \ldots \ldots \ldots \ldots \ldots \ldots \ldots \ldots$

5.1 .1 Roller Mills $\ldots \ldots \ldots \ldots \ldots \ldots \ldots \ldots \ldots \ldots \ldots \ldots \ldots, \quad 5.1$

5.1.2 High-Pressure Roller Press $\ldots \ldots \ldots \ldots \ldots \ldots \ldots \ldots \ldots .6 .2$

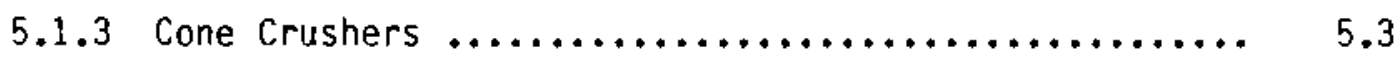

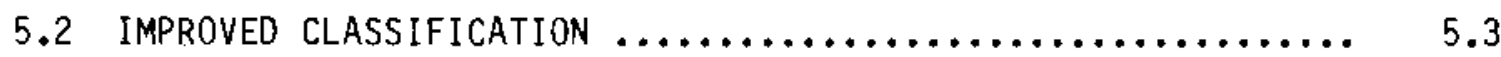

5.2.1 Energy-Savings Potential $\ldots \ldots \ldots \ldots \ldots \ldots \ldots \ldots \ldots . . . \ldots .6$

5.2 .2 Possible Barriers $\ldots \ldots \ldots \ldots \ldots \ldots \ldots \ldots \ldots \ldots \ldots . .6 .5$

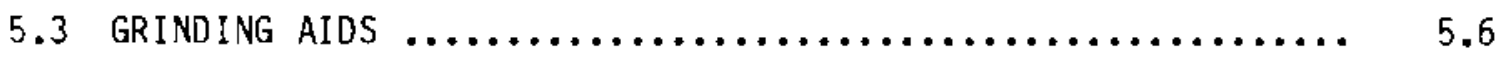

5.4 GRINDING MEDIA AND MILL LINING $\ldots \ldots \ldots \ldots \ldots \ldots \ldots \ldots \ldots . \ldots . . \ldots \ldots$

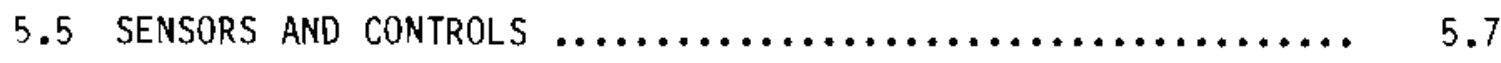

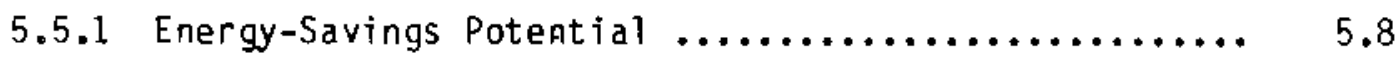

5.5 .2 Possible Barriers $\ldots \ldots \ldots \ldots \ldots \ldots \ldots \ldots \ldots \ldots \ldots . . . \ldots .6$

5.6 MODIFYING FINENESS SPECIFICATIONS $\ldots \ldots \ldots \ldots \ldots \ldots \ldots \ldots \ldots \ldots \ldots \ldots \ldots \ldots \ldots$

5.6.1 Energy-Savings Potential $\ldots \ldots \ldots \ldots \ldots \ldots \ldots \ldots \ldots, \quad 5.8$

5.6 .2 Possible Barriers $\ldots \ldots \ldots \ldots \ldots \ldots \ldots \ldots \ldots \ldots . . . \ldots . . .6$

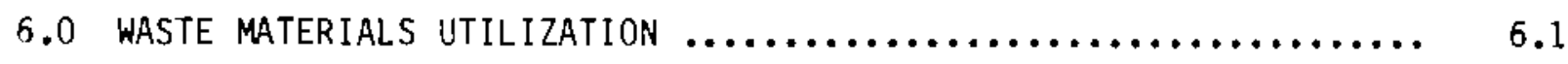


6.1 WASTE MATERIALS AS FUELS $\ldots \ldots \ldots \ldots \ldots \ldots \ldots \ldots \ldots \ldots \ldots \ldots \ldots \ldots \ldots \ldots, 6.1$

6.1 .1 Municipal Wastes $\ldots \ldots \ldots \ldots \ldots \ldots \ldots \ldots \ldots \ldots \ldots \ldots, 6.1$

6.1 .2 Rice Hulls and Wood Wastes $\ldots \ldots \ldots \ldots \ldots \ldots \ldots \ldots, 6.2$

6.1 .3 Rubber Tires $\ldots \ldots \ldots \ldots \ldots \ldots \ldots \ldots \ldots \ldots \ldots \ldots \ldots, 6.3$

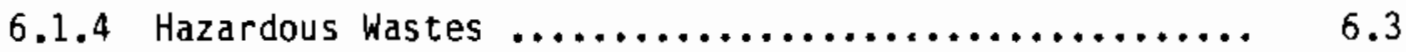

6.1 .5 waste $0 i 1 \ldots \ldots \ldots \ldots \ldots \ldots \ldots \ldots \ldots \ldots \ldots \ldots \ldots, 6.4$

6.1.6 Energy-Savings Potential ..................... 6.5

6.1 .7 Possible Barriers $\ldots \ldots \ldots \ldots \ldots \ldots \ldots \ldots \ldots \ldots \ldots . . .6 . .6$

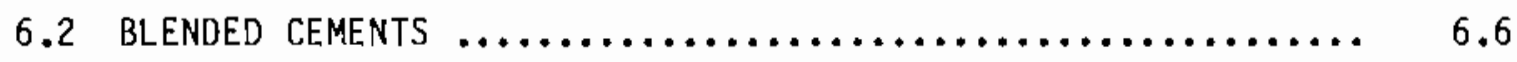

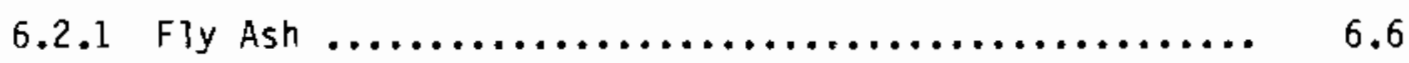

6.2 .2 Blast Furnace $\operatorname{slag} \ldots \ldots \ldots \ldots \ldots \ldots \ldots \ldots \ldots \ldots, 6.6$

6.2 .3 Cement $k i l n$ Dust $\ldots \ldots \ldots \ldots \ldots \ldots \ldots \ldots \ldots \ldots \ldots, 6.7$

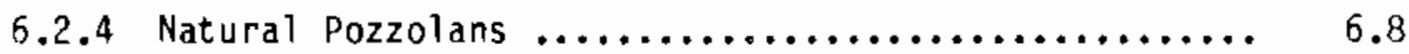

6.2.5 Energy-Savings Potential $\ldots \ldots \ldots \ldots \ldots \ldots \ldots \ldots \ldots \ldots, 6.8$

6.2 .6 Possible Barriers.$\ldots \ldots \ldots \ldots \ldots \ldots \ldots \ldots \ldots \ldots \ldots \ldots .6 .6$

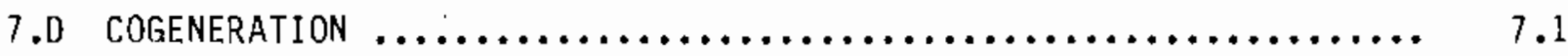

7.1 STEAM RANKINE CYCLE $\ldots \ldots \ldots \ldots \ldots \ldots \ldots \ldots \ldots \ldots \ldots \ldots \ldots \ldots \ldots \ldots \ldots \ldots \ldots \ldots, 7.1$

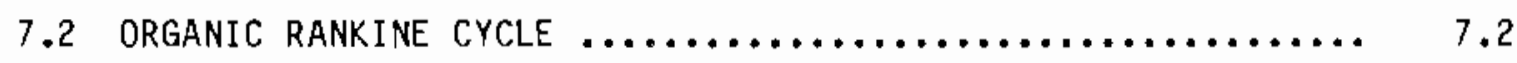

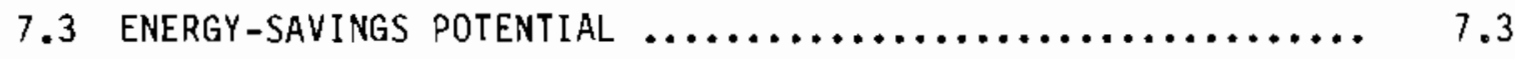

7.3.1 Steam Rankine Cycle $\ldots \ldots \ldots \ldots \ldots \ldots \ldots \ldots \ldots \ldots . . . \ldots \ldots$

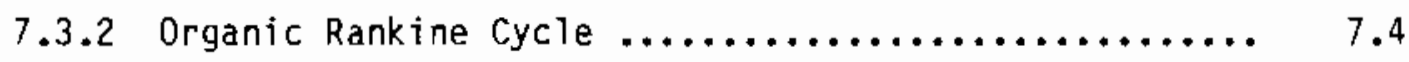

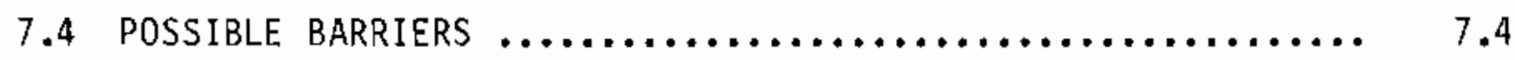

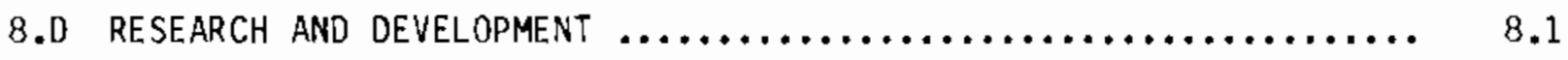

8.1 CURRENT RESEARCH $\ldots \ldots \ldots \ldots \ldots \ldots \ldots \ldots \ldots \ldots \ldots \ldots \ldots \ldots \ldots \ldots \ldots \ldots \ldots, 8.1$

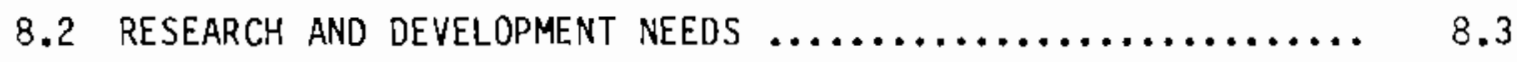


8.2.1 Kiln Thermal Efficiency $\ldots \ldots \ldots \ldots \ldots \ldots \ldots \ldots \ldots, \quad 8.4$

8.2 .2 Grinding Methods $\ldots \ldots \ldots \ldots \ldots \ldots \ldots \ldots \ldots \ldots \ldots . . .6 .7$

8.2 .3 Waste Materials Utilization $\ldots \ldots \ldots \ldots \ldots \ldots \ldots \ldots . .6 . .8$

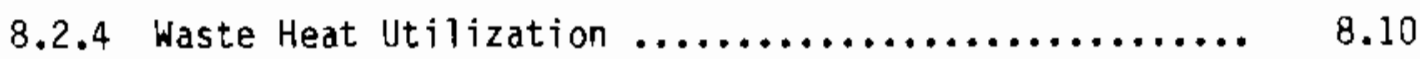

8.2.5 Process/Product Development $\ldots \ldots \ldots \ldots \ldots \ldots \ldots \ldots \ldots . \quad 8.12$

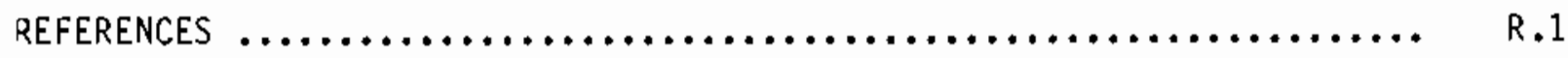

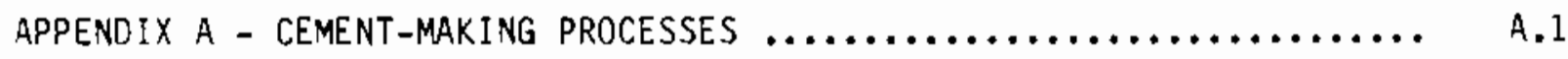

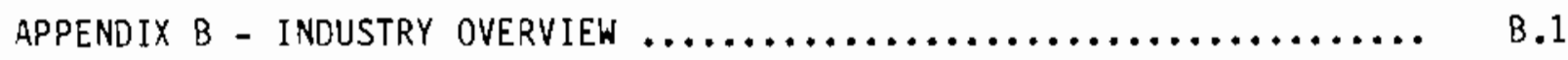

APPENDIX $C$ - SUMMARY TABLES OF INDIVIDUAL PLANT STATISTICS $\ldots \ldots \ldots \ldots c$ c.

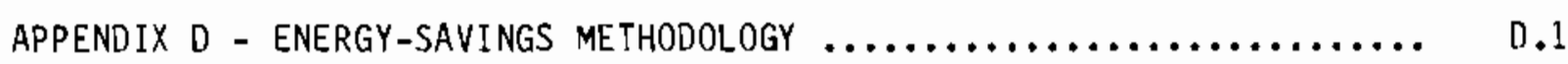




\section{FIGURES}

S.1 Differences Between the Theoretical and Actual Fuel Use in the Cement Industry $\ldots \ldots \ldots \ldots \ldots \ldots \ldots \ldots \ldots \ldots \ldots \ldots \ldots . \ldots \ldots$ viii

2.1 U.S. Cement Production, 1972 to $1983 \ldots \ldots \ldots \ldots \ldots \ldots \ldots \ldots \ldots \ldots . \ldots \ldots$

2.2 Trends in Fuel-Use Mix, 1972 to $1982 \ldots \ldots \ldots \ldots \ldots \ldots \ldots \ldots \ldots \ldots$

2.3 Self-Generated Electricity, 1972 to $1982 \ldots \ldots \ldots \ldots \ldots \ldots \ldots \ldots . . . \ldots$

2.4 Cement Industry Unit Power Consumption, 1972 to $1982 \ldots \ldots \ldots \ldots . . .2 .10$

2.5 Energy-Efficient Wet Process Flow Diagram ................ 2.13

2.6 Energy-Efficjent Long-Dry Process Flow Diagram ............. 2.14

2.7 Energy-Efficient Preheater Process Flow Diagram ............. 2.15

2.8 Energy-Efficient Precalciner Process Flow Diagram ........... 2.16

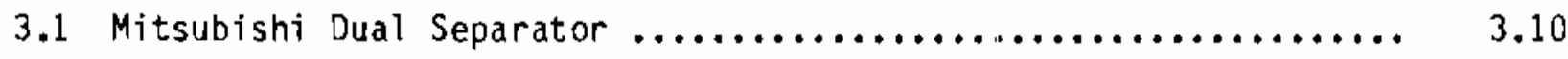

4.1 Fuller-Humboldt Four-Stage Suspension Preheater ............ 4.3

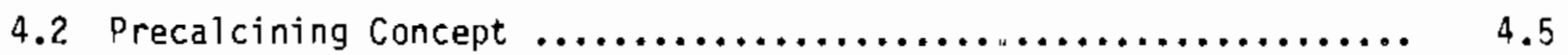

4.3 Examples of Three Basic Precalciner Types ................ 4.6

4.4 Conceptual Bendy Engineering Fluid-Bed kiln .............. 4.15

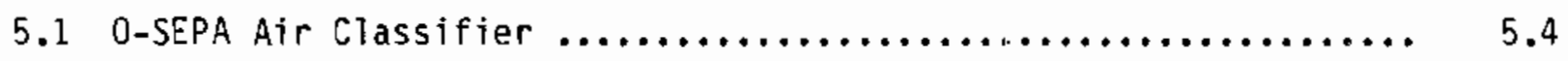

7.1 Organic Rankine Bottoming Cycle $\ldots \ldots \ldots \ldots \ldots \ldots \ldots \ldots \ldots \ldots \ldots \ldots . . \ldots$ 


\section{TABLES}

S.1 Estimates of the Energy-Savings Potential of Current and Advanced Technologies Relative to 1982 Base Year ............. ix

S.2 Conservation-Related Research and Development Activities ...... xi

S.3 Potential R\&D Opportunities for Saving Energy in the

Cement Industry .................................. xi

2.11982 Energy Consumption in the Cement Industry $\ldots \ldots \ldots \ldots \ldots \ldots \ldots .4$

2.21982 Distribution of Production and Fossil Fuel

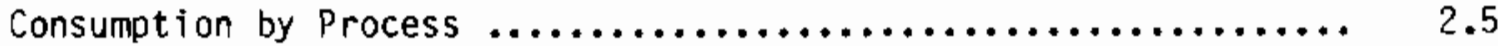

2.3 Cement Industry Fuel Source Mix, 1972 and $1982 \ldots \ldots \ldots \ldots \ldots \ldots .2 .7$

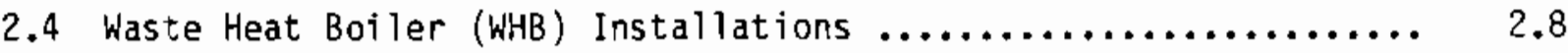

$2.5198:$ Distribution of Production and Energy Consumption

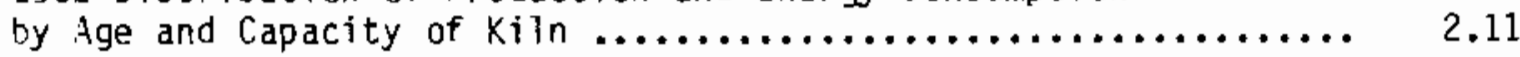

2.6 Suminary of Cement Process Energy Use $\ldots \ldots \ldots \ldots \ldots \ldots \ldots \ldots \ldots \ldots \ldots . \ldots \ldots$

3.1 Comsarison of Installed and Alternative Systems for Thræe Cement Plants ................................... 3.4

3.2 Comorative Capital Cost Data $\ldots \ldots \ldots \ldots \ldots \ldots \ldots \ldots \ldots \ldots \ldots \ldots \ldots . \ldots \ldots$

3.3 Comsarative Operating Cost Data $\ldots \ldots \ldots \ldots \ldots \ldots \ldots \ldots \ldots \ldots \ldots \ldots . \ldots \ldots$

4.1 Suspension Preheater Developers $\ldots \ldots \ldots \ldots \ldots \ldots \ldots \ldots \ldots \ldots \ldots . . \ldots \ldots$

4.2 Heat Balance Comparison of Efficient Wet and Dry Processes ..... 4.7

4.3 Fuel-Savings Potential of Dry Process Kilns Relative to the Wet Process .......................... 4.8

4.4 Case Studies of Wet Process to Dry Process Conversion ......... 4.11

4.5 Advanced Fluid-Bed Heat Balance $\ldots \ldots \ldots \ldots \ldots \ldots \ldots \ldots \ldots \ldots \ldots . \ldots . \ldots . \ldots . \ldots$

4.6 Comparison of Fuel Savings for kilns with and without
Chain Systems $\ldots \ldots \ldots \ldots \ldots \ldots \ldots \ldots \ldots \ldots \ldots \ldots \ldots \ldots \ldots \ldots \ldots \ldots \ldots \ldots$

5.1 Additives Used in Cement Industry Grinding Operations ........ 5.6

6.1 Relative Costs of Fuels Used at Genstar's Redding, California Plant .................................. 6.4 
6.2 Cost/Benefit of Hazardous Waste Incineration $\ldots \ldots \ldots \ldots \ldots \ldots \ldots . . . .6$

6.3 Approximate Energy-Savings Potential of Blended Cements or Cement Substitutes ......................... 6.9

A.1 Raw Materials Used in U.S. Portland Cement Manufacture ........ A.2

A.2 Wet and Dry Process Reaction Temperatures ................. A.4

A.3 Theoretical Heat Requirement to Produce Cement Clinker ........ A.4 


\subsection{INTRODUCTION}

Most of the technological changes that have occurred in the cement industry have been and are expected to continue to be related to energy use. This focus reflects the high percentage of the value added in manufacture that is attributable to energy costs (about 53\%). (a) Within the constraints of capital availability, technological changes are expected to continue with retrofitting preheaters and precalciners on existing dry kilns and incorporating these technologies in any new capacity because these technologies offer significant energy savings and increased kiln capacity.

Whereas fossil fuel prices currently are relatively stable, the price of power continues to escalate. Thus, power consumption is emerging as a significant energy concern of the industry. Most of the electricity used in a typical cement plant is for finish grinding. Technologies that lead to more efficient finish grinding are likely to face a receptive audience (again within the industry's capital constraints). In addition, as power costs continue to rise, industry interest in the use of waste heat boilers to generate electricity is expected to increase.

In yeneral, the cement industry's lack of capital is constraining the adoption of energy-saving technologies. This lack of capital is largely a result or a sluggish construction industry and increased foreign imports. The demand for portland cement clinker (b) is tied closely to the health of the construction industry.

For the last ten years, the cement industry has operated below capacity, with a capacity utilization as low as $70 \%$ in recent years. As of December 31 , 1983, the U.S. cement industry had a total capacity of 88.3 million tons of clinker. Projections of clinker demand to 1990 indicate that current capacity

(a) Based on data from the Department of Commerce.

(b) Portland cement is the predominant type of cement. Over $95 \%$ of the cement produced in the U.S. is portland cement, with masonry cement and mortar accounting for most of the balance. Portland cement was patented by Joseph Aspdin of Leeds, England in 1824. The name "portland" was selected because the set cement resembled a building stone quarried from the Isle of Portland off the southern coast of England (Dikeou 1980). 
is more than sufficient to handle the expected modest increase in demand. No new kilns are currently under construction in the United States, nor do any of the projects currently under consideration appear close to construction start up (PCA 1984). In the past ten years, net industry capacity has remained relatively stable, although the number of cement kilns has declined from 445 in 1973 to 274 in 1983. This reflects the trend toward fewer, larger-capacity kilns.

Foreign companies are expected to continue to expand their share of domestic cement markets in coming years through imports and through ownership of domestic plants. In 1982, imports accounted for $4 \%$ of domestic consumption. Foreign firms had acquired $24 \%$ of the U.S. clinker production capacity and $25 \%$ of the finish grinding capacity by the end of 1982 (Johnson and Absalom 1982). As the demand for cement increases, increasing imports will reduce the need for expansion of U.S. clinker capacity.

Although the American cement industry was responsible for inventing the rotary kiln in the late 19th century, most of the recent innovations in cement processing equipment have come from Japan and Europe. Foreign dominance of cement technology development has been attributed to the following (National Materials Advisory Board 1980):

- the relatively low expenditures by the U.S. cement industry for research and development $(0.03 \%$ of gross sales in 1980)

- the lack of adequate undergraduate training in cement science and technology in the U.S. (West Germany, Czechoslovakia, Poland and the Soviet Union have institutes that offer special courses for cement scientists and technologists.)

- the U.S. cement industry's generally low return on investment in recent years, which deters any increase in nonmanufacturing expenditures

- U.S. anti-trust restrictions (vertical integration), which appear to hinder scientific and technological cooperation between producers and users (National Materials Advisory Board 1980). 
This report is divided into 8 chapters and 4 appendices. In Chapter 2 , an energy-use profile of the cement industry is presented. Currently available and advanced technologies that have the potential for energy savings are then identified and analyzed, respectively, in Chapters 3 through 5 for the three basic operations in cement manufacturing: raw material preparation, pyroprocessing, and finish grinding. In Chapter 6, the use of waste materials as raw materials or as fuel in cement-making operations is discussed. The energysaving potential of two cogeneration technologies that are applicable to the cement industry is described in Chapter 7. Finally, in Chapter 8 R\&D opportunities that will either improve the energy-saving capabilities of current technologies or mitigate problems associated with their use, or which will advance the development of new energy-saving technologies are listed. Appendix A provides a brief overview of the cement-making process. Appendix $B$ provides an overview of the cement industry and Appendix $C$ contains summary tables of individual plant statistics. Appendix 0 discusses in more detail the methodology used to calculate the energy-savings potential of the current and advanced technologies applicable to the cement process. 


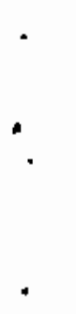

.

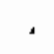

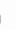




\subsection{CEMENT INDUSTRY ENERGY USE}

This chapter presents an energy profile of the cement industry. The first section provides energy data for the year 1982; the second section describes historical energy use by the cement industry; and the third section is an overview of the energy used in specific cement-making operations.

The energy-use data presented in this chapter are from: the Portland Cement Association (PCA) and the Bureau of Mines (BuMines). The PCA data generally provide more detail than the Bumines data. The inconsistencies in the figures quoted from these two sources arise because the surveys on which the data are based vary. BuMines data are based on 100\% of the industry, whereas the PCA data for 1982 represent 93\% of the industry.

Energy-use figures are given both in terms of energy used per ton of clinker Jroduced and as energy used per ton of cement produced. The latter includes the energy used to grind imported clinker. In 1982, 525,000 tons of cement were produced from imported clinker and in 1981, 1,276,000 tons of cement were produced from imported clinker (Johnson and Absalom 1982). The PCA provides figures for energy used per "equivalent" ton of cement produced, which is a weighted average that accounts for the imports.

\subsection{BASELINE ENERGY PROFILE}

The cement industry used about 361 trillion Btu of energy in 1982 (Johnson and Absalom 1982). Although the energy used per unit weight of portland cement is low compared to other manufactured building materials, the cost of energy to produce sement as a percentage of its market value is high. In 1981, energy costs accounted for $53 \%$ of the value added in manufacture. (a) This clearly indicates why energy use is a major concern of the cement industry.

The energy profile of the cement industry that is presented in this section is intended to serve as the baseline for analyzing the energy-savings potential of current and advanced conservation technologies in subsequent chapters. At the time this report was prepared, the most current published data

(a) Based on data from the Census of Manufactures, Department of Commerce. 
avajlable for both production and energy use by the cement industry was for the year 1982. Thus, 1982 became the base year for the energy profile.

\subsubsection{Economic Climate}

The 1982 energy data presented in the following section must be viewed within the context of the economic environment in which the industry operated during that time period. Production and consumption of cement declined to a seven-year low in 1982 as a result of reduced construction and continued weakness in the U.S. economy (see Figure 2.1). Production in 1982 was down 11\% from the previous year and was $25 \%$ below the peak production year of 1979 (Rock Products 1983).

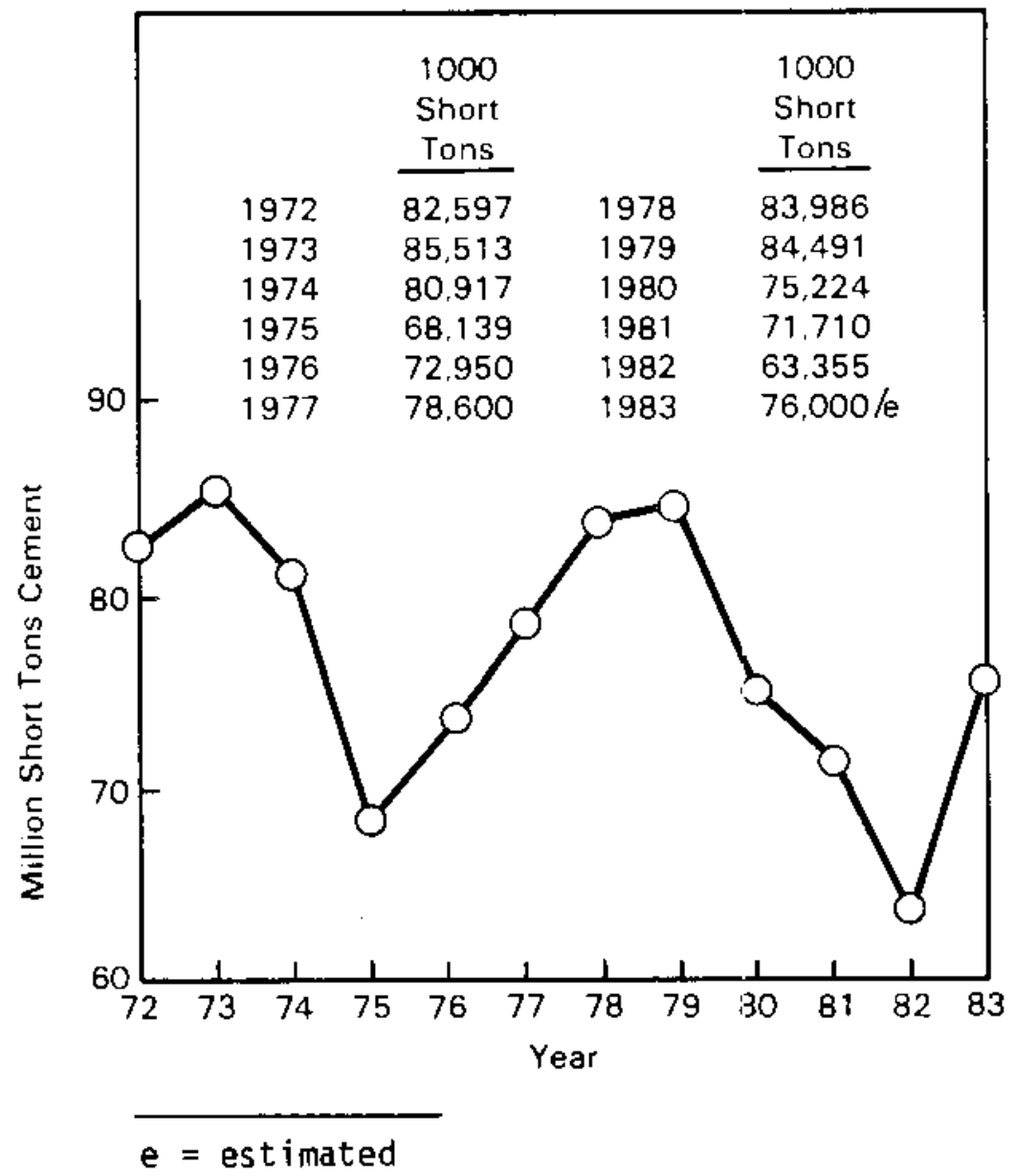

FIGURE 2.1. U.S. Cement Production, 1972 to 1983 (Bumines 1984) 
Capacity utilization in 1982 was reported to be $58.7 \%$ based on clinker production as a ratio of finish grinding capacity (Rock Products 1983). However, PCA states that finish grinding capacity is not a good measure of cement plant capacity in most cases. It is not a good measure because grinding capacity is sized to handle both kiln output and clinker inventory during the peak summer building season and is not intended to operate year-round (PCA 1984). Capacity utilization was about $64 \%$ in 1982 , calculated on the basis of clinker capacity.

Regardless of the figure that is chosen to represent capacity utilization, operating below capacity tends to reduce specific fuel use and increase specific power use. The industry tends to shut down its older, least-efficient clinkering capacity first as the market for cement becomes soft, leaving the tnost efficient plants on-line. Operating the most efficient plants lowers the industry average fuel use per unit of product produced. Because plant electricity use is largely independent of throughput, operating at less than optiinal capacity tends to drive up the electrical energy use per unit of product produced.

\subsubsection{Base-Year Energy Use}

The following energy-use data for the cement industry include statistics on the fuel-use mix, the energy use per ton of clinker, and the energy use per equivalent (a) ton of cement.

Table 2.1 provides total use figures for fuel and electricity for 1982 as well as suel and electricity use per equivalent ton of cement. In cement manufacture, 91\% of the energy used is provided by fossil fuels. Coal and coke are the dominant fuels used to fire the kilns. The cement industry uses almost 10\% of the coal used by the industrial sector(b) and uses more coal than any other manufacturing industry in this country. Waste materials that have been used as

(a) An equivalent ton is defined as the weighted average of clinker production (92\%) and cement production (8\%).

(b) The industrial sector is defined by the Energy Information Administration, U.S. Department of Energy, as manufacturing, construction, mining, agriculture, fishing, and forestry (Energy Information Administration Monthly Publications). 
TABLE 2.1. 1982 Energy Consumption in the Cemerit Industry (Roy 1983) (a,b, c)

Gasoline
Middle Distillates
Residual 0il
LPG
$\quad$ Total Liquid Petroleum Fuels

Coal

Petroleum Coke

Total Coal and Coke

Natural Gas

Waste Fuel

Total Fossil Fuels

Purchased Electricity

Self-Generated Electricity

Total Electricity

TOTAL FUEL AND POWER

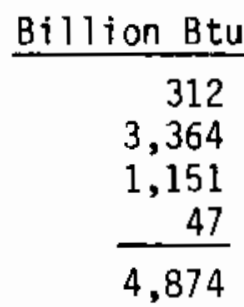

223,611

13,267

236,878

27,887

498

270,138

27,018

$\frac{1,079}{28,097}$

298,235
Thousand Btu/

Equivalent Ton

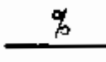

6

61

21

$\frac{1}{89}$

1.6

89

$$
4,047
$$

240

4,287

79.4

504

9.4

0.2

90.6

$\frac{9}{4,890}$

489

20

9.4

509

5,399

(a) The utility losses are not accounted for in converting kWh to Btu in this table. That is, the conversion factor used is $3413 \mathrm{Btu} / \mathrm{kWh}$.

(b) Numbers may not add to total due to independent rounding.

(c) Figures include process and nonprocess uses of energy.

fuels include rice hulls, waste oils, and rubber tires. Electricity consumption accounts for $9 \%$ of the total cement industry energy use. In 1982, 4 plants generated a total of $316 \mathrm{kWh}$ (1078.5 billion Btu) of electricity on site. That total represented about $3.5 \%$ of the industry's power use.

Table 2.2 shows the percentage of total clinker production and the fossil fuel consumption by type of process. The quantity of clinker produced by the dry process exceeded that produced by the wet process, and dry process kilns consumed 28\% less fuel per ton of clinker than wet process kilns. In 1982 out of a total of 139 operating plants, 64 used the wet process, 69 used the dry process, and 6 used both processes (Rock Products 1983). In 1982, the most 
TABLE 2.2. 1982 Distribution of Production and Fossit Fuel

Consumption by Process (Roy 1983)

\begin{tabular}{|c|c|c|}
\hline Process & $\begin{array}{l}\text { Clinker } \\
\text { Production } \\
(\%) \\
\end{array}$ & $\begin{array}{c}\text { Kiln Fossil Fuel } \\
\text { Consumed } \\
\left(10^{6} \text { Btu/ton clinker }\right)\end{array}$ \\
\hline Wet & 39.6 & 5.611 \\
\hline Dry & 60.4 & 4.041 \\
\hline Dry no Preheater & 21.7 & 4.698 \\
\hline Dry with Preheater & 38.7 & 3.729 \\
\hline All Processes & 100.0 & 4.707 \\
\hline
\end{tabular}

efficient cement plant used 2.8 million Btu of fossil fuel per ton of clinker produced, and the least efficient plant used 7.9 million Btu of fossil fuel per ton of clinker (Roy 1983).

The fuel use per ton of clinker in 1982 averaged about 5.0 million Btu. The theoretical enthalpy required to produce a ton of clinker is $1.5 \mathrm{million}$ 3tu. These figures suggest that about $3.5 \mathrm{million} B t u / t$ on of heat was lost during clinker manufacture, which amounts to about 200 trillion Btu of heat rejected from clinker production operations in 1982. Industrywide, about $45 \%$ of this reat is rejected as sensible heat in exhaust gases, about $30 \%$ is in the form of latent heat of vaporization of water, $22 \%$ is low-temperature, diffuse radiant leat, and $3 \%$ is clinker sensible heat.

\subsection{HISTORICAL ENERGY USE}

The cement industry has one of the highest ratios of energy cost to total materials cost of any manufacturing process. Consequently, the cost and availability of energy are major concerns of the industry. Rising prices and interruptible supplies of fuel in the early seventies instigated efforts to increase energy efficiency and to convert to lower-price sources of energy. Between 1972 and 1982, total energy use decreased by $40 \%$, and energy used per ton of output declined by $20 \%$.

In the following two subsections, the changes in fuel and electricity use are discussed and in the third subsection, energy conservation trends in the industry since 1972 are described. 


\subsubsection{Fuel Use}

Fuel use in the cement industry changed dramatically during the ten-year period from 1972 to 1982 . The industry had been largely dependent on natural gas because of its convenience, availability, low cost, and clean burning characteristics. However, rising prices and interruptible supplies in the early seventies prompted the industry to switch from natural gas and oil to coal and coke as its major fuels. Figure 2.2 shows the marked increase in the use of coal since 1972. Table 2.3 compares the fuel use in 1972 to fuel use in 1982.

The dramatic increase in oil and natural gas prices initiated by the OPEC embargo in 1973 provided the cement industry with major incentives for reducing the use of these fuels. During this time, the industry reduced its use of petroleum products by $92 \%$ and its use of natural gas by $88 \%$. The use of coal and coke increased $33 \%$ in this period, despite the higher cost of environmental controls associated with their use.

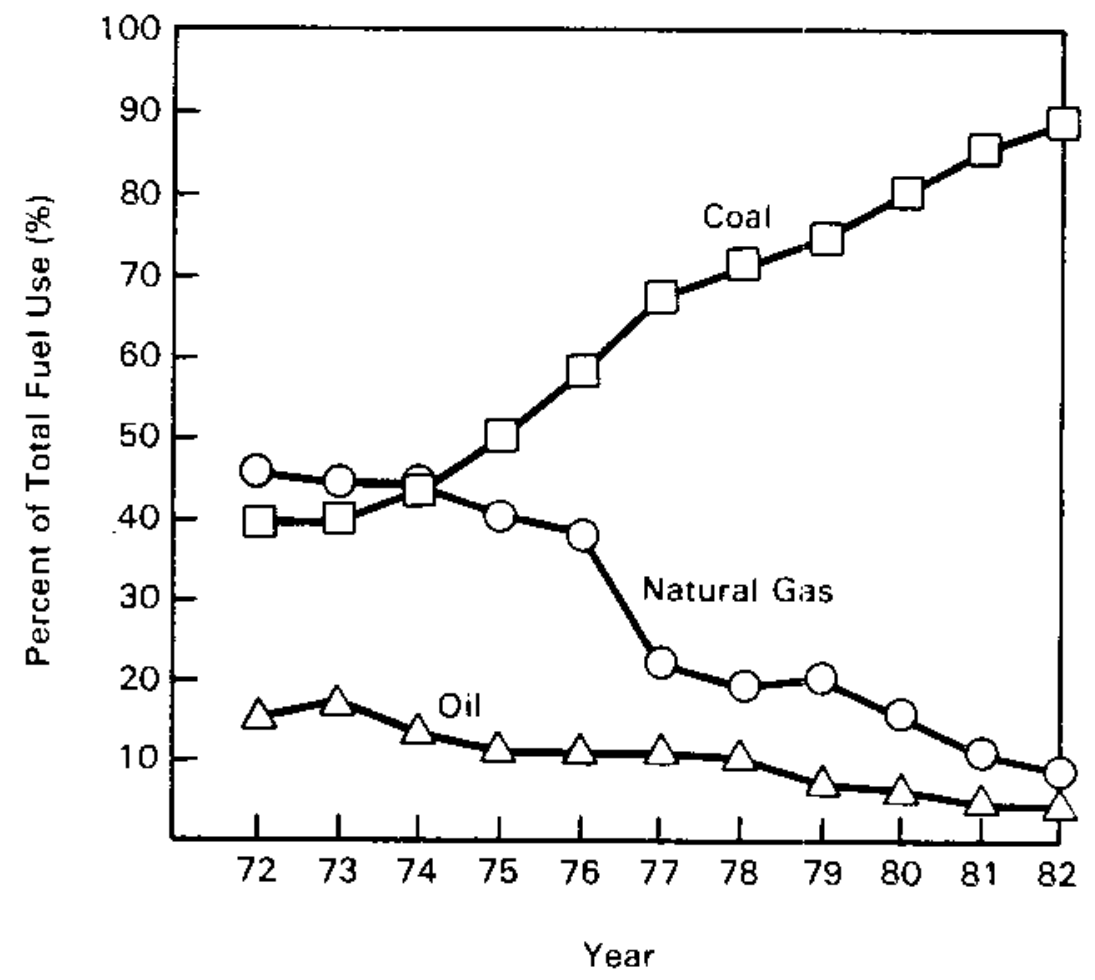

FIGURE 2.2. Trends in Fuel-Use Mix, 1972 to 1982 (data from Bullines 1972-1982) 
TABLE 2.3. Cement Industry Fuel Source Mix, 1972 and 1982

(Roy 1983)

\begin{tabular}{|c|c|c|c|c|c|}
\hline & \multicolumn{2}{|c|}{1972} & \multicolumn{2}{|l|}{1982} & \multirow[b]{2}{*}{ Change } \\
\hline & Billion Btu & $(\%)$ & Billion Btu & $(\%)$ & \\
\hline Coal and Coke & 178,059 & $(38.6)$ & 236,878 & $(87.7)$ & $+33.0 \%$ \\
\hline Natural Gas & 222,495 & $(48.3)$ & 27,887 & $(10.3)$ & $-87.5 \%$ \\
\hline Petroleum Products & 60,224 & $\langle 13.1\rangle$ & 4,874 & $(1.8)$ & $-91.9 \%$ \\
\hline Waste Fuel & 0 & $(0.0)$ & 498 & $(0.2)$ & -- \\
\hline \multirow[t]{2}{*}{ Total Fossil Fuel } & $460,77 \mathrm{~B}$ & 100.0 & 270,138 & 100.0 & $-41.4 \%$ \\
\hline & \multicolumn{2}{|c|}{1972} & \multicolumn{2}{|l|}{1982} & \\
\hline $\begin{array}{l}\text { Btu per Equivalent } \\
\text { Ton }\end{array}$ & \multicolumn{2}{|c|}{$6,302,000$} & \multicolumn{2}{|c|}{$4,889,000$} & $-22.4 \%$ \\
\hline $\begin{array}{l}\text { Equivalent Tons of } \\
\text { Cement Production }\end{array}$ & \multicolumn{2}{|c|}{$73,121,000$} & \multicolumn{2}{|c|}{$55,252,000$} & $-24.4 \%$ \\
\hline
\end{tabular}

Was:e fuels are also beginning to find use in the cement industry, including rice hulls, wood chips, rubber tires, waste-derived oils (Segal 1984; Reber 1984) and battery cases. Some European cement plants are investigating the use of municipal wastes and hazardous wastes.

\subsubsection{Electricity Use}

Electricity accounts for about $9 \%$ of the total energy used in a typical cement plant, but accounts for an average of one-third of the energy cost. It is used srimarily to operate crushing and grinding equipment, materials handling equipment, machine drives (e.g., kiln rotation) and pumps and fans for pollution control equipment.

Most electricity is purchased from central-station utilities. In the early 1930s, it was fairly common to use waste heat boilers to recover heat from $k i l l$ exhausts to generate steam for power production. These original waste heat boilers were an integral part of the plant design. Currently, four dry process plants continue to operate waste heat boilers that were originally installed when the plants were constructed. One company is in the process of retrofitting waste heat boilers on two dry process kilns. Statistics for these cogeneration plants are provided in Table 2.4. 
TABLE 2.4. Waste Heat Boiler (WHB) Installations

\begin{tabular}{|c|c|c|c|}
\hline Company & Location & $\begin{array}{c}\text { Number of } \\
\text { WHBs }\end{array}$ & $\begin{array}{c}\text { Year } \\
\text { Installed } \\
\end{array}$ \\
\hline Riverside Cement & $\begin{array}{l}\text { Oro Grande, } \\
\text { California }\end{array}$ & 7 & $\begin{array}{l}1956(2) \\
1978(5)\end{array}$ \\
\hline National Gypsum & $\begin{array}{l}\text { Alpena, } \\
\text { Michigan }\end{array}$ & 9 & $\begin{array}{l}1954(4)(a) \\
1962(1) \\
1965(2) \\
1975(2)\end{array}$ \\
\hline $\begin{array}{l}\text { Lehigh Portland } \\
\text { Cement }\end{array}$ & $\begin{array}{l}\text { Independence, } \\
\text { Kansas }\end{array}$ & 3 & $\begin{array}{l}1918(2) \\
1920(1)\end{array}$ \\
\hline SME Cement, Inc. & $\begin{array}{l}\text { Sylvania, } \\
\text { Ohio }\end{array}$ & 3 & $1923(3)$ \\
\hline $\begin{array}{l}\text { California } \\
\text { Portland Cement }\end{array}$ & $\begin{array}{l}\text { Colton, } \\
\text { California }\end{array}$ & 2 & $1985(2)^{(b)}$ \\
\hline
\end{tabular}

(a) Not currently operating.

(b) Under construction.

Figure 2.3 shows the trend in self-generation of power since 1972 . The general decline reflects the retirement of older kiln capacity that had integrated waste heat boilers. The new installation at Colton, California, will have 2 waste heat boilers with a combined capacity of 10 MW integrated with a 15-MW coa1-fired fluidized bed boiler (Pit \& Quarry 1983).

Figure 2.4 shows the change in the power use per ton of cement since 1972. The increased use of electricity per ton of cement partially results from the fact that when production is down, the electricity used to operate crushing and grinding equipment remains largely the same. Thus, the sharp decreases in production shown earlier in Figure 2.1 correspond to the sharp increases in power use per ton shown in Figure 2.4. In addition, power needs have increased as a result of more stringent environmental regulations, greater use of "dirty" coal, and the conversion to the preheater process. In 1972, electricity accounted for $6.6 \%$ of the energy used by the industry. By 1982 , electricity use had increased to $9.4 \%$ of total energy use. 


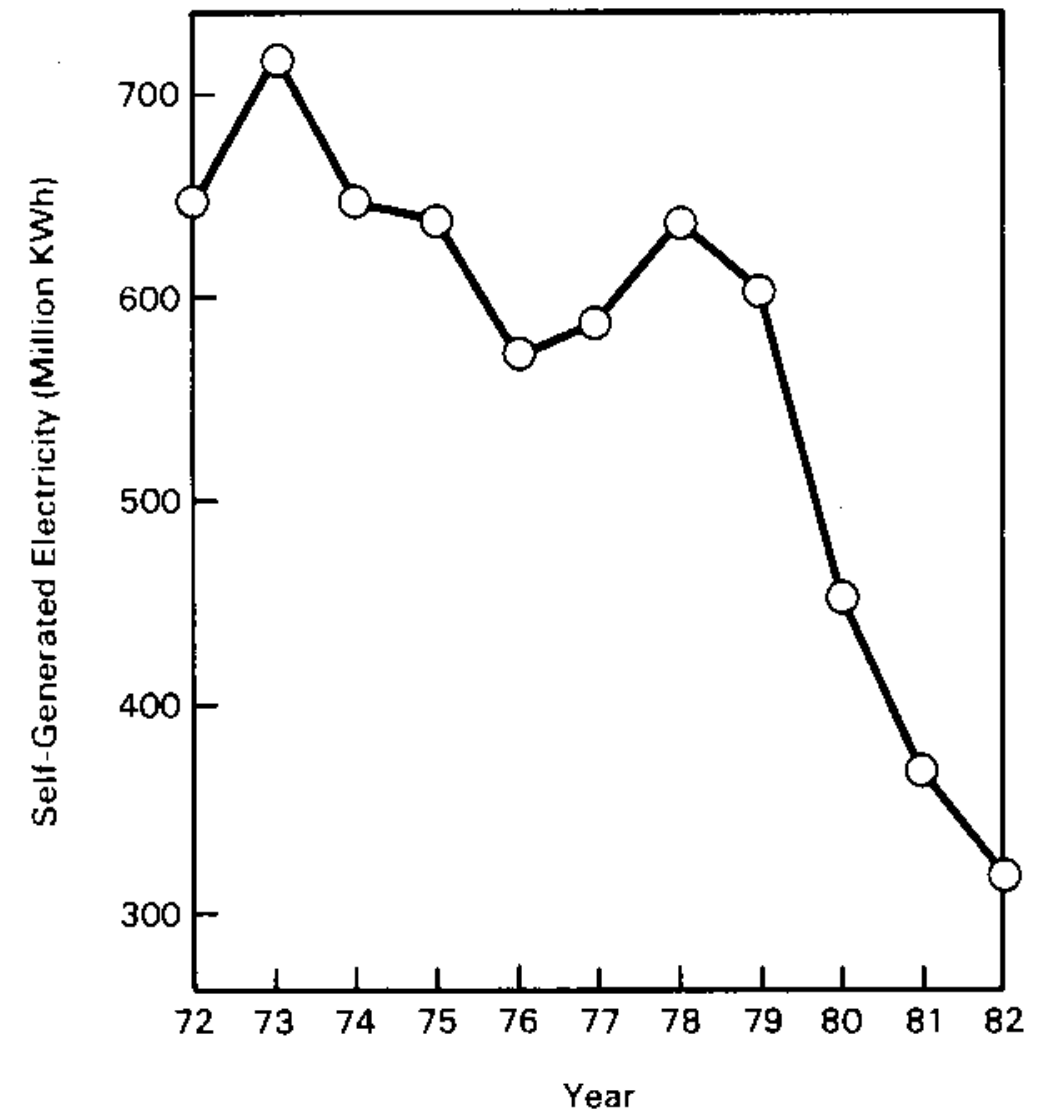

FIGURE 2.3. Self-Generated Electricity, 1972 to 1982 (data from BuMines 1972-1982)

The preheater kiln requires more induced-draft fan power than the long-dry kiln because of the added pressure drop across the preheater and the alkali bypass sustem. The Portland Cement Association reports that the steady increase in power use since 1972 seems to have plateaued at $141 \mathrm{kWh} /$ ton of output since 1979. The $149 \mathrm{kWh} /$ ton peak in 1982 is probably due to a loss of efficiency resulting from reduced production levels during the economic recession (Roy 1983).

\subsubsection{Conservation Trends}

The U.S. cement industry made significant progress in conserving energy between 1972 and 1982. During this period, total energy consumption by cement 


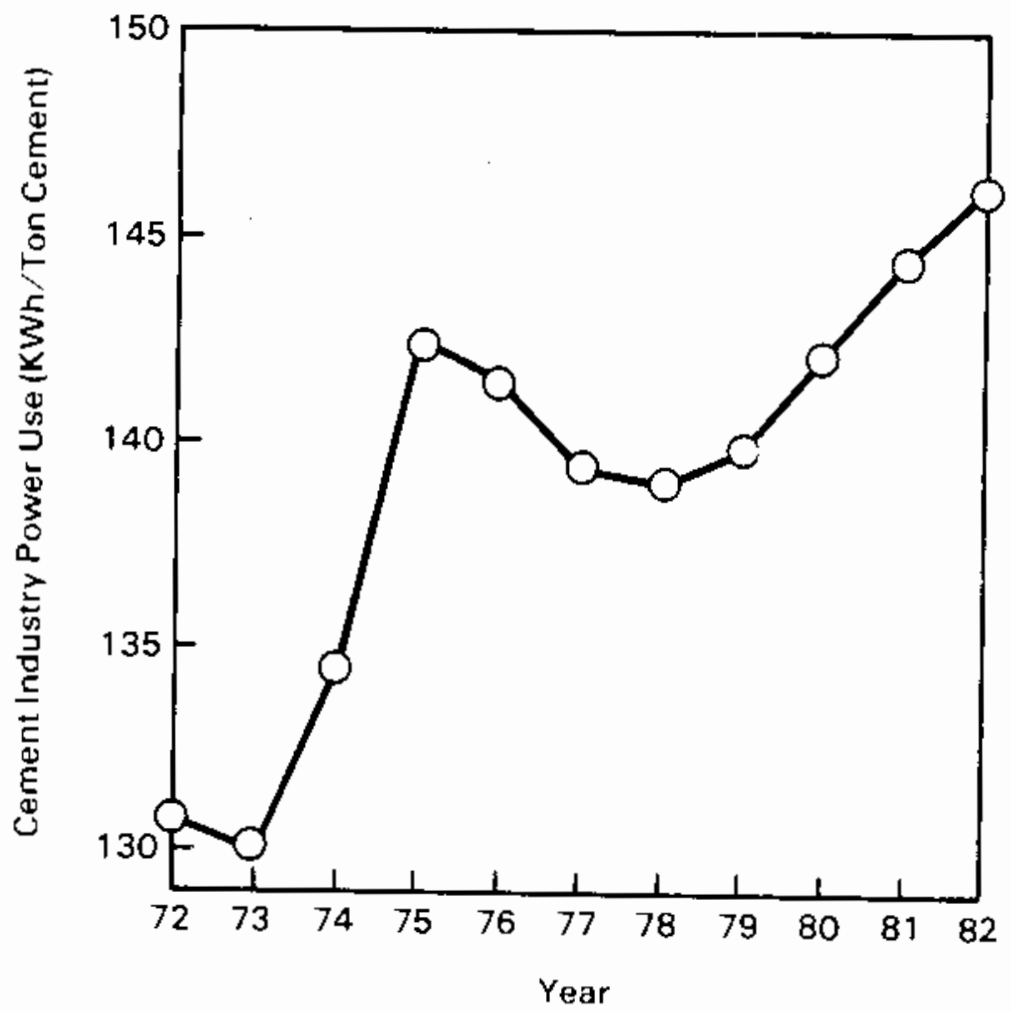

FIGURE 2.4. Cement Industry Unit Power Consumption, 1972 to 1982 (data from BuMines 1972-1982)

producers decreased $40 \%$. In terms of Btu/ton of zement, energy consumption decreased $20 \%$. Most of the energy conservation can be attributed to the following:

- closing of older, less efficient mills as new, more energy-efficient, larger-capacity kilns were brought on-line

- conversion of wet process plants to dry process plants

- improved kiln heat transfer through the installation of internal heat transfer enhancement devices, such as chains, crosses and trefoils

- adoption of preheaters and precalciners.

Almost $30 \%$ of the present IJ.S. cement capacizy has been built or modernized since 1972. Kilns built after 1972 are abouz 15\% more efficient than the oldest kilns, which were brought on-line between 1910 and 1953. Nearly 85\% of the new capacity added since 1972 uses the dry process. On average, the newer dry process kilns have nearly twice the capacity of older kilns. Only 1 of the 
22 kilns built or modernized since 1976 uses the wet process. O1der, wetprocess silns have been retired in recent years at nearly the same rate that new dry capacity has been added. Thus, the cement industry has become more energy-efficient without increasing its total capacity. In 1981, for the first time in 'J.S. history, the amount of clinker produced by the dry process exceeded that produced by the wet process. Currently, the average age of U.S. cement kilns is 18 years and the average capacity is 322,300 tons per year (PCA 1984).

Table 2.5 shows the fossil fuel consumed and the percentage of clinker produced as a function of the age of the kiln and kiln capacity. In 1982, fuel consumption by wet process kilns averaged $5.6 \mathrm{million} B$ tu/ton of clinker compared to an average of 4.0 for dry process kilns. A comparison of the percent of capacity and the fuel used by wet and dry process kilns was presented earlier in Table 2.2 .

TABLE 2.5. 1982 Distribution of Production and Energy Consumption by Age and Capacity of KiIn (Roy 1983)

\begin{tabular}{|c|c|c|}
\hline Age of $k i l n$ & $\begin{array}{l}\text { CTinker } \\
\text { Production } \\
(\%) \\
\end{array}$ & $\begin{array}{l}\text { Kiln Fossit Fuel } \\
\text { Consumed } \\
\left(10^{6} \text { Btu/ton clinker }\right)\end{array}$ \\
\hline 1972 and Tater & 29.7 & 3.889 \\
\hline $1966-1971$ & 25.6 & 4.807 \\
\hline $1960-1965$ & 21.2 & 4.927 \\
\hline $1954-1959$ & 10.4 & 5.254 \\
\hline 1953 and earlier & 13.2 & 5.581 \\
\hline \multicolumn{3}{|c|}{ Kiln Capacity (tons) } \\
\hline 150,000 or less & 1.9 & 6.193 \\
\hline $150,000-299,999$ & 11.3 & 5.552 \\
\hline $300,000-449,999$ & 22.4 & 4.760 \\
\hline $450,000-599,999$ & 25.6 & 4.503 \\
\hline 600,000 or more & 38.8 & 4.499 \\
\hline
\end{tabular}


The majority of the new dry kilns are equipped with preheaters or precalciners. Currently almost half of the dry kiln capacity uses preheaters and about $25 \%$ of these are precalciners. Between $40 \%$ and $50 \%$ of the feed is calcined in the preheater as it contacts the kiln exit gases (Garrett 1980). Precalciners accomplish up to $90 \%$ of the calcining before the feed enters the kiln (United Technologies Corporation 1980).

The sharp increase in the price of electricity with respect to recently stabilized fuel prices has sparked considerable interest in electricity-saving technologies. Because finish grinding accounts for the majority of plant electricity use (40 to 50\%), technologies that improve grinding circuit efficiency are being developed and implemented. In addition, some plants (e.g., Monarch cement) operate grinding mills to take advantage of lower rates during off-peak periods. As power rates approach about $\$ 0.07 / \mathrm{kWh}$, the use of waste heat boilers for power generation is becoming attractive. Other plants are considering converting to the less-fuel-efficient wet process, which uses less electricity per ton of cement.

\subsection{PROCESS ENERGY USE}

In this section, the differences in the energy use of the major operations used in the wet and dry processes are discussed.

The energy used in a cement plant is a function of the type of process, the age and capacity of the equipment, and the type of raw materials used. Thus, the energy profile of each cement plant is unique and must be evaluated within the context of its own operating characteristics. Thus, the information summarized in the process flowsheets (Figures 2.5 through 2.8 ) and presented in the following sections represents an industry average, not a particuiar plant.

For discussion purposes, cement manufacturing is divided into three basic operations: 1) raw material preparation, 2) pyroprocessing (burning), and 3) finish grinding. These operations are described in detail in Appendix $A$.

\subsubsection{Raw Materials Preparation}

The energy used in raw materials preparation includes the fuel and electricity used to transport the raw materials, the electricity used to crush, 


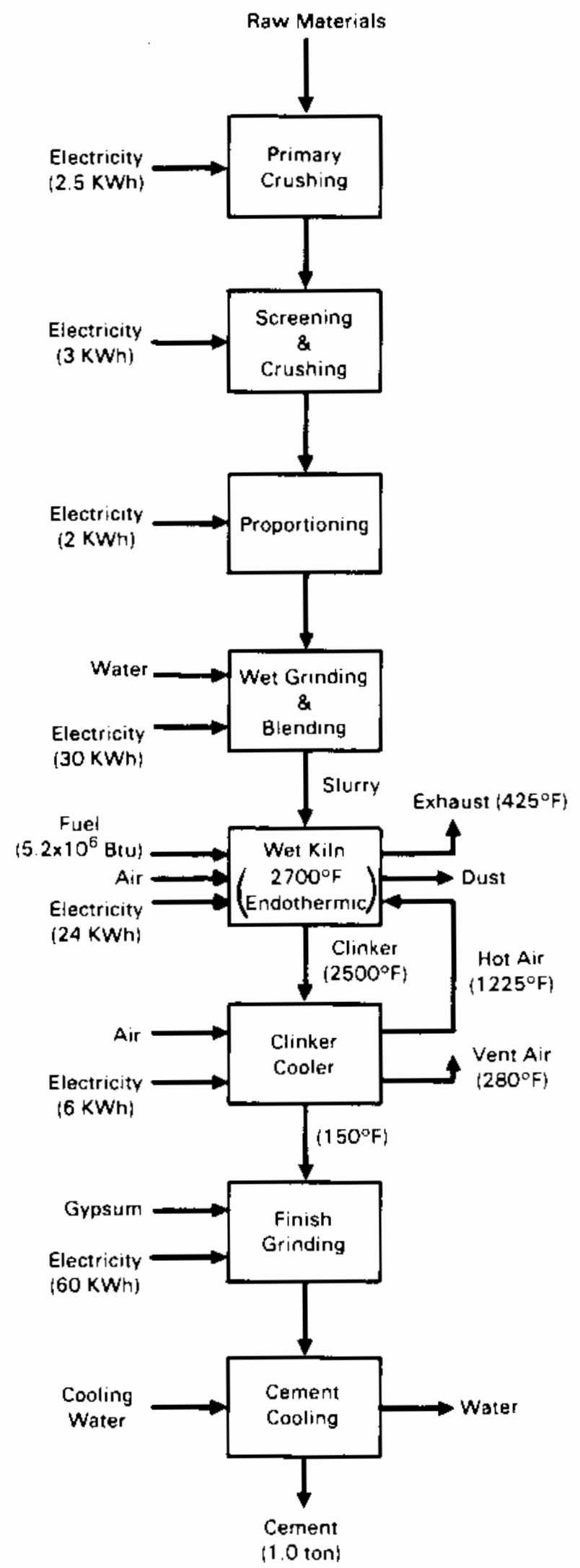

FIGURE 2.5. Energy-Efficient wet Process Flow Diagram 


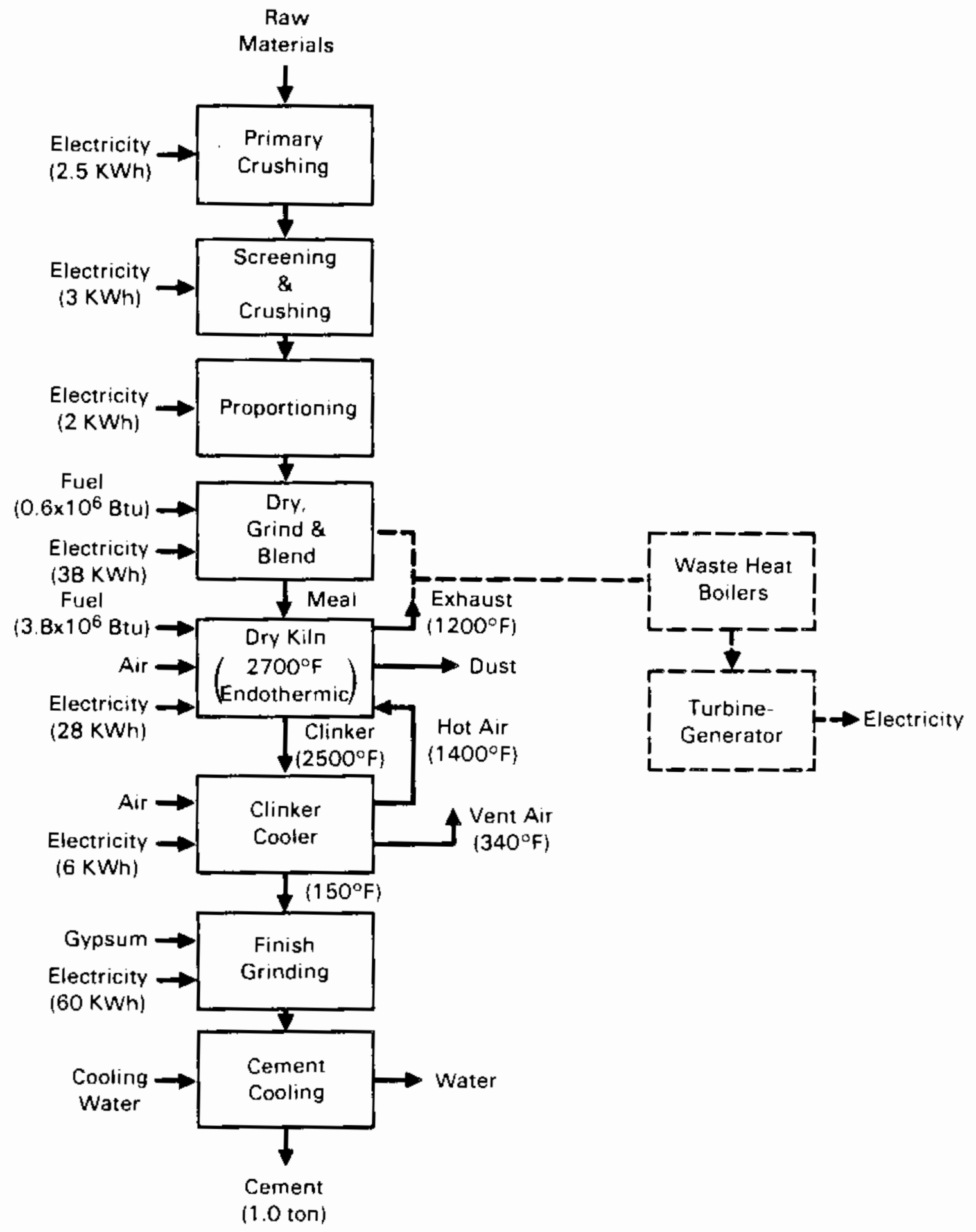

FIGURE 2.6. Energy-Efficient Long-Dry Process Flow Diagram 


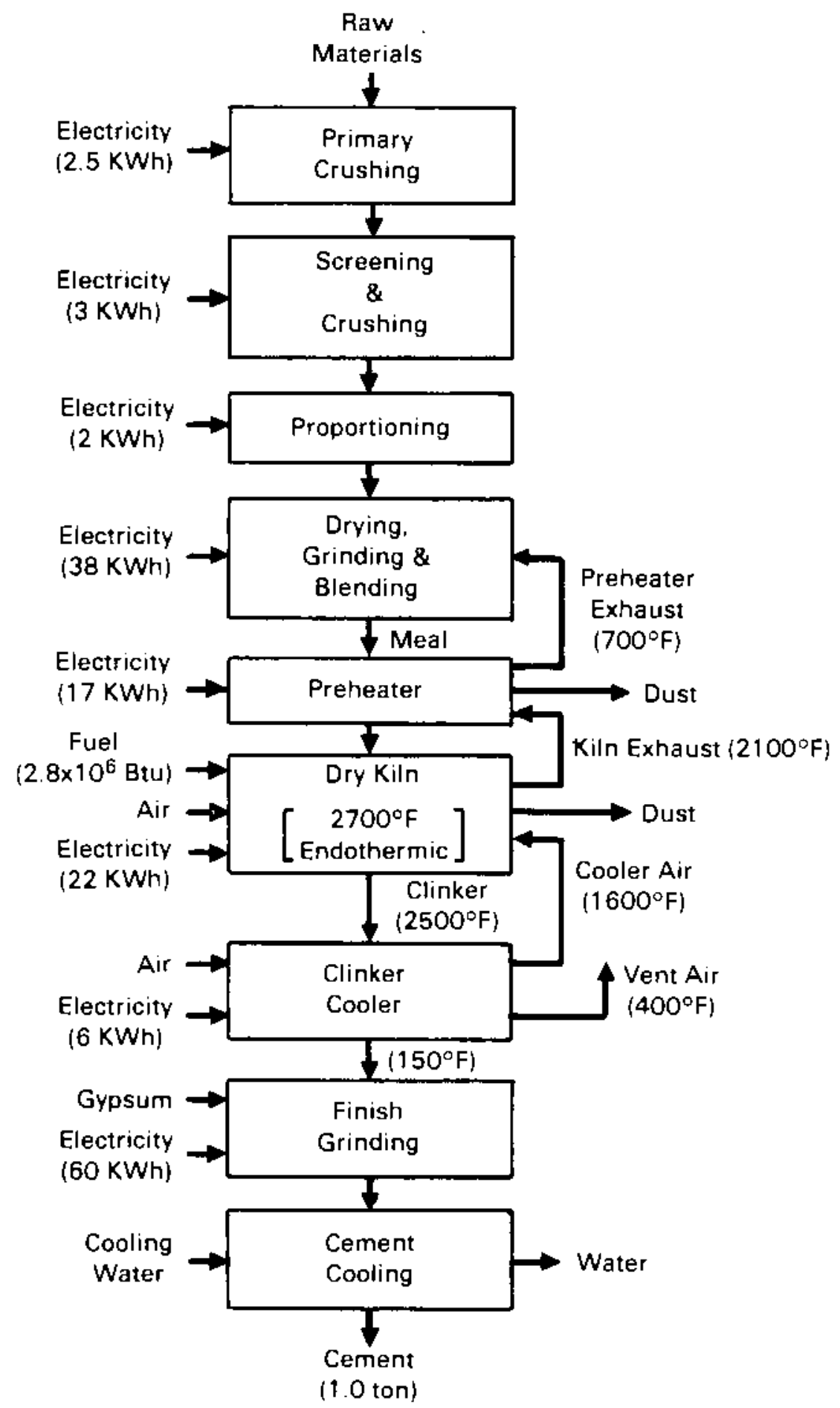

FIGURE 2.7. Energy-Efficient Preheater Process Flow Diagram 


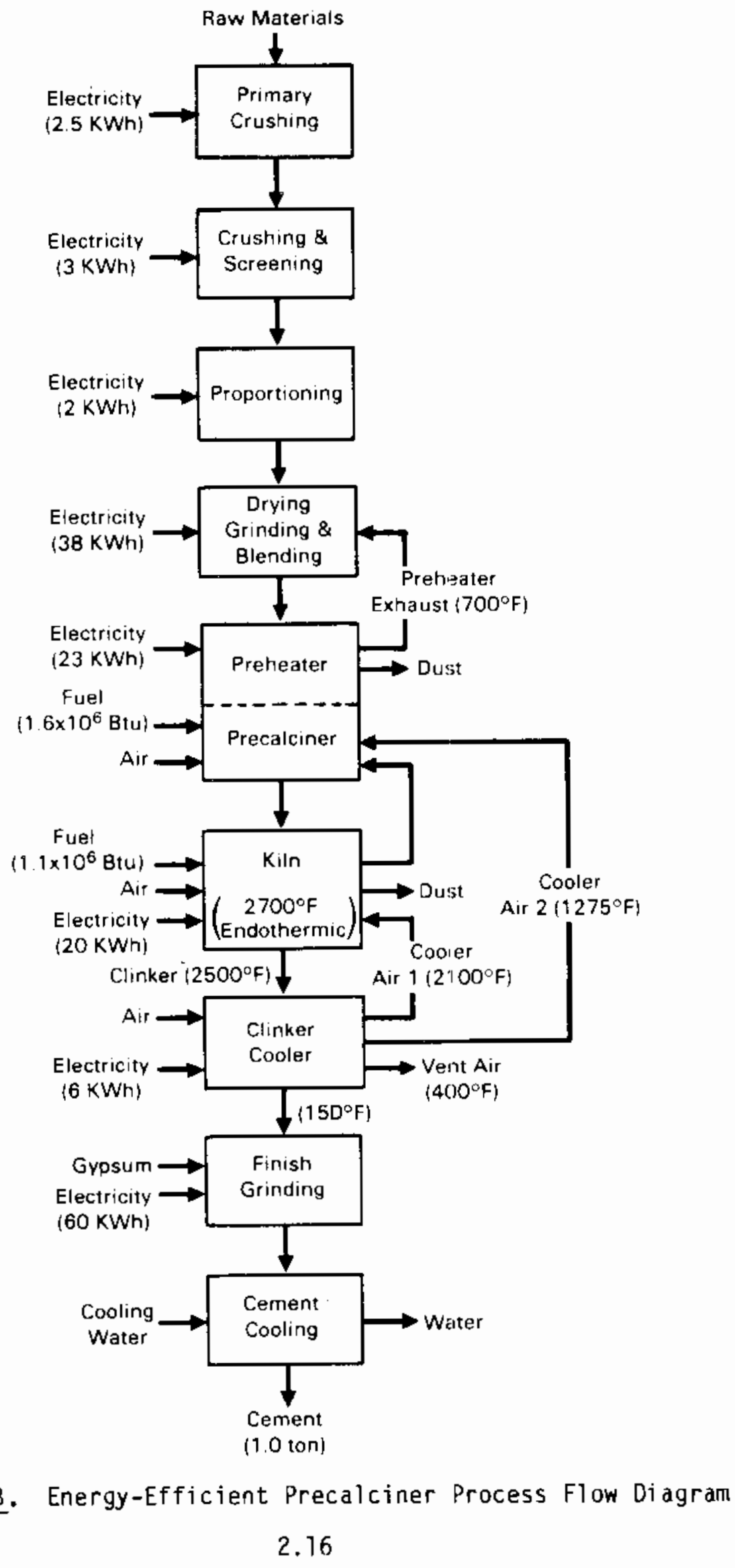


grind and blend the raw materials, the fuel used to dry the raw materials, and the electricity used to convey the feed to the kiln.

The power needs of the crushing and grinding equipment dominate other uses of electricity in raw materials preparation. Comminution (crushing and grinding) operations are reportedly only about $5 \%$ efficient in converting input energy to increased surface area (PCA 1975). Dry process grinding may require $10 \%$ to $50 \%$ more power than wet process grinding because of the use of dryer drives, fans and dust control equipment (McIvor 1983). In addition, wet process hydraulic conveying and classifying equipment is more efficient than comparable dry process pneumatic equipment (Garrett and Murray 1974). Finely divided raw materials have lower power requirements because only moderate grinding is required, whereas higher power requirements are associated with larger, larder rocks.

\subsubsection{Pyroprocessing}

Buring is the most energy-intensive step in manufacturing cement. The theoretical enthalpy requirement for clinker manufacture is $1.5 \times 10^{6}$ 3tu/ton. Average $1982 \mathrm{kiln}$ energy use for the four basic cement processes was presented earlier in Table 2.2. The most efficient process, the dry kiln with precalciner, uses more than twice as much energy as the theoretical enthalpy requirement. The other processes are even less efficient. The wet process has the highest energy use because of the need to evaporate the water in the feed.

Electricity is used in the pyroprocessing step mainly for machine drives (for kiln rotation) and for fan power (for clinker cooling and for introducing the pulverized coal into the kiln). Approximately $20 \%$ of the total plant power requirement is used in these operations. The preheater and precalciner processes require more power than the long-dry process. The added pressure drop across the preheater and the alkali bypass system requires additional induceddraft fan power for operation.

\subsubsection{Finish Grinding}

Power used in finishing mills to grind the clinker to a fine powder accounts for as much as $50 \%$ of a plant's electricity use. Again, grinding 
processes are very inefficient; over $90 \%$ of the energy is converted to heat, whereas as little as $1 \%$ is used to produce additional surface area.

On a worldwide basis, about $36 \mathrm{kWh}(122,900 \mathrm{Btu})$ are used to grind each ton of Clinker (Frigione, Zenone and Esposito 1983). In general, the U.S. consumes $15 \%$ to $25 \%$ more power in finish grinding than most other countries. The higher power consumption of the U.S. cement industry is attributable to product specifications that require higher surface area for high early strength and lower free lime content for volume stability (PCA 1975). The higher surface area specification requires additional grind"ng, whereas the lower specification for free lime requires that the clinker be more completely burned, which results in a harder clinker requiring additional grinding power.

\subsubsection{Summary of Process Energy Use}

The process energy use information presented in the preceding three sections is summarized in Table 2.6.

TABLE 2.6. Summary of Cement Process Energy Use (million Btu per ton cement equivalent)

\begin{tabular}{|c|c|c|c|}
\hline & Wet & Dry & $\begin{array}{l}\text { Preheater/ } \\
\text { Precalciner }\end{array}$ \\
\hline Crushing & 0.03 & 0.03 & 0.03 \\
\hline Grinding & 0.11 & 0.13 & 0.13 \\
\hline Conveying & 0.02 & 0.02 & 0.02 \\
\hline Pyroprocessing & 5.75 & 4.73 & 3.76 \\
\hline Finish Grinding & 0.21 & 0.21 & $\underline{0.21}$ \\
\hline Total & 6.12 & 5.12 & 4.15 \\
\hline
\end{tabular}




\subsection{RAW MATERIAL PREPARATION}

In this chapter, the energy-savings potential of various technologies relating to raw material preparation. Included are technologies that improve the efficiency of raw material crushing and grinding equipment, reduce the moisture content of slurries, or provide alternative means of drying raw mea1. Specifically, the following technologies are discussed:

Crushing and Grinding

- roller mills

- autogenous or semi-autogenous mills

- particle classification systems

- grinding media and lining materials

- sensors and controls

- differential grinding

Slurry Dewatering

- slurry filters

- slurry thinners

Raw Material Drying

- waste heat utilization

- fluidized-bed dryers

\subsection{CRUSHING AND GRINDING IMPROVEMENTS}

Over $95 \%$ of the energy input to grinding mi1ls ends up as waste heat, whereas less than $1 \%$ of the input power is used to create new surface, which is the objective of grinding (Hartley, Priestly and Wick 1978). These figures clearly - llustrate the need for energy-efficiency improvements in crushing and grinding operations. In this section, currently available and emerging technologies that reduce the energy used to crush and grind raw materials or to grind clinker are discussed. These technologies include alternative types of crushing and grinding mills, advanced computerized control of grinding circuits, improved particle classification systems, and use of differential grinding. 


\section{1 .1 Roller Mills}

Roller mills are used almost exclusively for raw material grinding in Japan. The roller mills are beginning to replace conventional rod and ball mills for raw material grinding in the U.S.

Roller mills reduce the size of the feed material as rollers or comparable grinding elements travel over a circular bed of material. After the material passes under the rollers, it undergoes preliminary classification with an air stream flowing through the mill. This air stream carries a portion of the pulverized material to an air classifier, which is normally an integral part of the mill. Oversized particles are rejected by the classifier and are sent back to the mill. Fines are collected in filters or cyclones.

Because a considerable amount of air is needed to carry the pulverized material from the mill to the classifier, roller mills are particularly suited for combining raw material drying with the grinding process. These mills can use large quantities of waste heat from kilns or clinker coolers. Using this waste heat, roller mills can effectively dry material with $10 \%$ to $12 \%$ moisture and using an auxiliary heating unit, materials with $25 \%$ to $28 \%$ moisture can be dried (Dikeou 1980).

Although the capital cost of a roller mill is $10 \%$ to $15 \%$ higher than the conventional rod or ball mills, the roller mill is more compact, requires less horsepower and is quieter (Dikeou 1980). Using roller mills for raw material grinding may also eliminate the need for one stage of crushing because the mill can accept larger feed (up to 4 or 5 inches in diameter) than a conventional ball mill. Additional electricity and capital cost savings would result by eliminating one crushing stage. However, eliminating this stage may pose some additional problems with blending and proportioning systems.

One other advantage of the roller mills is the reduced wear compared to ball mills. Wear is reduced because in roller mills there is no direct metalto-metal contact as in the ball mills. 


\section{Energy-Savings Potential}

Roller mills use $40 \%$ to $50 \%$ of the power used by ball mills. However, when the additional fan power requirements are accounted for, it is estimated that roller mills can save an average of $5 \%$ to $15 \%$ of the energy used in conventional grinding circuits. The energy savings depends on the type of material being ground. For hard materials, roller mills can save $20 \%$ to $50 \%$ compared with ball mills.

At three Holderbank Financiere Glaris SA (Switzerland) cement plants, economic and technical aspects of the grinding systems currently in operation were compared with alternative systems. It was concluded that roller mills are usually preferred for raw materials that are not too abrasive or if $10 \mathrm{cal}$ conditions (e.g., availability of wear parts) do not present a barrier. Table 3.1 summarizes the results of the comparison.

Potential Barriers

The Portland Cement Association (1975) reported that soft, chalky limestones and marls are inefficiently ground in roller mills. However, engineers at Allis--Chalmers report that raw materials at each site must be evaluated independently to determine the most appropriate mill. Allis-Chalmers has had excellent success in using roller mills with both soft and sticky materials (e.g., roller mills are used with soft materials at the Kaiser Longhorn Plant and with sticky clay at a plant in Edmonton, Alberta).

0ther possible barriers that have been cited include (PCA 1975):

- Raw materials containing more than $3 \%$ quartz greatly increase the abrasion of working surfaces.

- Only the long-dry process produces enough waste heat to dry raw materials with moisture contents above $7 \%$.

- The roller mill may trap alkali, sulfur and halide materials, which may cause plugging.

The latter is not a problem specific to roller mills, but rather is a problem that may occur in any system that uses waste exhausts from the kiln. 
TABLE 3.1. Comparison of. Installed and Alternative Systems for Three Cement Plants (adapted from Huhta 1984b)

\section{Plant 1}

Raw Material

Composition:

- Limestone/Marl

- Clay

- Additives

- Moisture

Abrasiveness

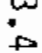

$$
\begin{array}{r}
98.0 \% \\
- \\
2.0 \% \\
3-4 \% \\
\text { high } \\
\text { low }
\end{array}
$$

Type of Mill

Capacity $(t / h)$

Mill Pressure Urop (in. WC)

Mill Exhaust Gas Volume (ACFII)

Specific Power

Consumption

(kWh/t)

\section{Plant 2}

$85.2 \%$

$14.2 \%$

$0.6 \%$

$4-6 \%$

medi um

$\underline{\text { Plant } 3}$

$79.5 \%$

\begin{tabular}{|c|c|c|c|c|c|}
\hline Installed & Alternate & Installed & Alternate & Installed & Alternate \\
\hline roller & $\begin{array}{l}\text { center- } \\
\text { discharge }\end{array}$ & $\begin{array}{c}\text { semi- } \\
\text { air-swept }\end{array}$ & roller & air-swept & roller \\
\hline 225 & 225 & 240 & 240 & 300 & 300 \\
\hline 30 & 15 & 20 & 32 & 24 & 34 \\
\hline 305,000 & 190,000 & 138,000 & 340,000 & 350,000 & 370,000 \\
\hline
\end{tabular}

$20.0 \%$

$0.5 \%$

$8-12 \%$

low

--
11.3
13.3
20.0
14.3
15.0
11.4 


\subsubsection{Autogenous Mills}

Autogenous grinding mills use large pieces of the feed material to perform the comminution function, rather than steel balls or other grinding media used in conventional mills. Autogenous grinding is used in 15 cement plants in the Soviet Union for the primary crushing of soft raw materials (Boldyrev 1983). With currently available autogenous mills, sufficient fineness cannot be achieved for kiln feed without further grinding (Labahn and Kohihaas 1983). Although autogenous mills are not currently used by the cement industry, they are of interest because of their wear rate and capital cost.

Because the raw materials used in cement are too low in density to grind properly in this system, steel balls must be used as the grinding medium in addition to large-diameter feed material. This is referred to as semi-autogenous grinding. While the grinding principle is the same for both types of milis, the autogenous mill requires a larger mill charge volume and a greater neight of fall of the grinding media to develop the same amount of comminution energy as a ball mill (Labahn and Kohlhaas 1983).

\section{Energy-Savings Potential}

The primary advantages of an autogenous mill are its lower capital cost and its lower rate of wear. However, currently available autogenous mills reportedly use $14 \%$ to $35 \%$ more power than conventional mills. A recent study reported that the total operating costs (including the cost of liner, media and screen replacement; maintenance supplies; labor; and power) of a semi-autogenous grinding circuit is slightly less than that of a conventional grinding circuit at power costs below $\$ .045 / \mathrm{kWh}$ for a 24,000 -metric-ton-per-day mill (Srinivasa 1983). Tables 3.2 and 3.3 provide comparative capital and operating cost data for the conventional and semi-autogenous grinding circuits at various capacities.

Another potential advantage of autogenous mills is that (like roller mills) they can accept larger feed sizes than conventional ball mills; thus, one stage of crushing could be eliminated. Eliminating that stage would result in both energy and capital savings. 
TABLE 3.2. Comparative Capital Cost Data (Srinivasa 1983)

(in militions of dollars)

\begin{tabular}{|c|c|c|c|c|c|c|}
\hline \multirow[b]{2}{*}{$\begin{array}{l}\text { Conventional } \\
\text { (Rod Mill - Ball Mill) }\end{array}$} & \multicolumn{6}{|c|}{ Metric Tons Per Day } \\
\hline & 12,000 & 24,000 & 36,000 & 48,000 & 72,000 & $90,00 \overline{0}$ \\
\hline $\begin{array}{l}\text { Coarse Ore Stockpile and } \\
\text { Conveying }\end{array}$ & 4.0 & 6.1 & 7.9 & 9.4 & 13.0 & 15.9 \\
\hline Fine Ore Crushing & 10.2 & 17.6 & 23.6 & 32.3 & 42.0 & 49.0 \\
\hline Fine Ore Storage & 1.0 & 2.7 & 3.4 & 4.1 & 5.2 & 5.9 \\
\hline Grinding & 8.1 & 16.1 & 24.5 & 32.3 & 47.8 & 57.4 \\
\hline Concentrator General & 2.0 & 3.6 & 5.8 & 7.4 & 9.6 & 12.1 \\
\hline Total & 25.3 & 46.1 & 65.2 & 85.8 & 117.6 & 140.3 \\
\hline Semi-Autogenous Grinding & & & & & & \\
\hline $\begin{array}{l}\text { Coarse Ore Stockpile, } \\
\text { Reclaim, and Convey }\end{array}$ & 2.2 & 3.7 & 5.0 & 5.7 & 7.5 & 10.7 \\
\hline Grinding and Classification & 15.3 & 29.7 & $4 \mathrm{D} .3$ & 52.7 & 80.7 & 100.9 \\
\hline Concentrator Genera 1 & 5.0 & 8.9 & 8.9 & 9.1 & 12.9 & 15.9 \\
\hline Total & 22.5 & 42.3 & 54.2 & 67.5 & 101.1 & 127.5 \\
\hline
\end{tabular}

\section{Potential Barriers}

The higher power requirement of semi-autogenous mills compared to conventional grinding mills and the escalating cost of electricity will likely be the major barriers to adopting autogenous grinding ci acuits.

\subsubsection{Improved Classification}

Closed-circuit grinding systems must separate the fine, product-quality particles from the coarser, oversize particles that are recycled for further grinding. To be effective, the separator (or classifier) must have good selectivity (defined as the percentage of a given particle size that is discharged in the recycle or tailings) to prevent recycling fines back to the mill. Conventional air classifiers typically recycle as much as $60 \%$ of the productquality fines back to the grinding mill. The result is overgrinding, which increases energy use in grinding and burning. 
TABLE 3.3. Comparative Operating Cost Data (Srinivasa 1983)

CONVENTIONAL GRINDING OPERATING COST

$$
\text { (1).S. } \$ / \text { metric ton }(\mathrm{m} / \mathrm{t}) \text { Ore) }
$$

1.1 Crushers

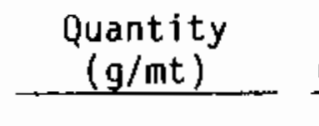

Cost

Metric Tons Per Day

$1.2 \operatorname{Rod} \mathrm{Mill}$

15.0

1.83

73.0

1.32

12,000

1.3 Ball Mill

167.0

1.32

$$
2.7
$$

2.7

$9.6 \quad 9.6$

2.7

2.7

2.

2.0 Media

2.1 Rods

275.0

0.72

22.1

22.1

9.6

9.6

$9.6 \quad 9.6$

2.2 Balls

601.0

0.55

19.8

19.8

22.

22.1

22.1

22.1

$\omega \quad 3.0$ screens

1.6

3.12

32.7

32.7

19.8

19.8

$\begin{array}{ll}19.8 & 19.8\end{array}$

4.0 Maintenance Supplies

(a)

0.5

0.5

32.7

32.7

$32.7 \quad 32.7$

5.0 Labor

6.0 Contingency

(b)

$\begin{array}{llllll}7.9 & 6.9 & 6.7 & 6.6 & 6.4 & 6.1\end{array}$

$\begin{array}{llllll}12.4 & 7.3 & 6.5 & 6.0 & 4.6 & 4.1\end{array}$

7.0 Subtotal

$\begin{array}{llllll}5.4 & 5.1 & 5.0 & 5.0 & 4.9 & 4.8\end{array}$

$\begin{array}{llllll}113.1 & 106.7 & 105.6 & 105.0 & 103.3 & 102.4\end{array}$

8.0 Power

$\underline{13.01 \mathrm{kWh} / \mathrm{mt}} 4.54 / \mathrm{kWh}$

$\begin{array}{llllll}58.5 & 58.5 & 58.5 & 58.5 & 58.5 & 58.5\end{array}$

9.0 Total Operating Cost

$\begin{array}{llllll}171.6 & 165.2 & 164.1 & 163.5 & 161.8 & 160.9\end{array}$

(a) $5 \%$ of equipment cost.

(b) Contingency is $5 \%$ of operating cost. 
TA8LE 3.3. (contd)

SEMI-AUTOGENDUS GRINOING OPERATING COST (U.S. $\$ / \mathrm{mt}$ Ore)

\begin{tabular}{|c|c|c|c|c|c|c|c|c|c|}
\hline & & $\begin{array}{c}\text { Quantity } \\
(\mathrm{g} / \mathrm{mt})\end{array}$ & $\begin{array}{c}\text { Cost } \\
(\$ / \mathrm{kg})\end{array}$ & \multicolumn{6}{|c|}{ Metric Tons Per Day } \\
\hline & Liners & & & & & & & & \\
\hline & 1.1 Semi-Autogenous & 117.0 & 1.65 & 19.3 & 19.3 & 19.3 & 19.3 & 19.3 & 19.3 \\
\hline & 1.1 Ball Mill & .97 .0 & 1.32 & 12.8 & 12.8 & 12.8 & 12.8 & 12.8 & 12.8 \\
\hline 2.0 & Media & & & & & & & & \\
\hline & 2.1 Semi-Autogenous & 450.0 & 0.59 & 26.5 & 26.5 & 26.5 & 26.5 & 26.5 & 26.5 \\
\hline & 2.2 Ball Mill & 315.0 & 0.55 & 17.3 & 17.3 & 17.3 & 17.3 & 17.3 & 17.3 \\
\hline 3.0 & Screen & 0.6 & 3.12 & 0.2 & 0.2 & 0.2 & 0.2 & 0.2 & 0.2 \\
\hline 4.0 & Maintenance & (a) & & 7.8 & 7.4 & 6.7 & 6.5 & 6.6 & 6.6 \\
\hline 5.0 & Labor & & & 8.4 & 6.0 & 5.1 & 4.1 & 3.0 & 2.6 \\
\hline 6.0 & Contingency & (b) & & 4.6 & 4.5 & 4.4 & 4.3 & 4.3 & 4.2 \\
\hline 7.0 & Subtotal & & . & 96.9 & 94.0 & 92.3 & 91.0 & 90.0 & 89.6 \\
\hline 8.0 & Power & $15.8 \mathrm{kWh} / \mathrm{mt}$ & $4.54 / \mathrm{kWh}$ & 71.1 & 71.1 & 71.1 & 71.1 & 71.1 & 71.1 \\
\hline 9.0 & Total Operating Cost & & & 168.0 & 165.1 & 163.4 & 162.1 & 161.1 & 160.7 \\
\hline
\end{tabular}

(a) $5 \%$ of equipment cost.

(b) Contingency is $5 \%$ of operating cost. 
Several companies have recently developed improved air classification systems. Whereas most of these are targeted primarily for finishing grinding applications (see Section 5.2), the Mitsubishi Dual Separator (MDS) system was developed specifically for raw material grinding.

The MDS system, shown in Figure 3.1, was developed for use in conjunction with a conventional center-discharge tube mi11. The MDS is composed of a rotary-selector, vane-type centrifugal classifier placed upon a gravity classifier. Conventional center-discharge mills use two kinds of separators: one to classify air-swept meal and one to classify mechanically elevated meal. The MDS system separates both the air-swept meal and the mechanically elevated meal. It controls the gas flow velocity in the classifying chamber with a fan that is independent of the classifier. The MDS is designed to avoid the formation of a gas circulating channel, which adversely affects the classifying efficiency by allowing the fine meal to become mixed with the coarse meal.

\section{Energy-Savings Potential}

Mitsubishi reports that the separation curve (percentage of a given particle size that is discharged in the mill tailing or recycle plotted against the particle size) is steeper for the MDS system than for conventional classifiers. Also, the separation rate of fine meal into coarse meal is reduced to about $15 \%$ with the MDS, compared to about $25 \%$ for a conventional system (Kokubu and Katsuki 1983). Mitsubishi reports about a $10 \%$ reduction in energy use in the whole grinding process compared with a conventional center-discharge mill (Kokubu and Katsuki 1983). In addition, the investment cost is reported to be about $10 \%$ lower, and easier operation and maintenance are expected.

\section{Possible Barriers}

No barriers to adopting this technology have been identified other than the industry's lack of capital to invest in any new equipment.

\subsubsection{Differential Grinding}

The particle size distribution of the raw meal plays an important role in the energy used during pyroprocessing. In general, it has been determined that the more finely ground the raw mix, the lower the required pyroprocessing temperature or the shorter the reaction time at higher temperatures. Studies 


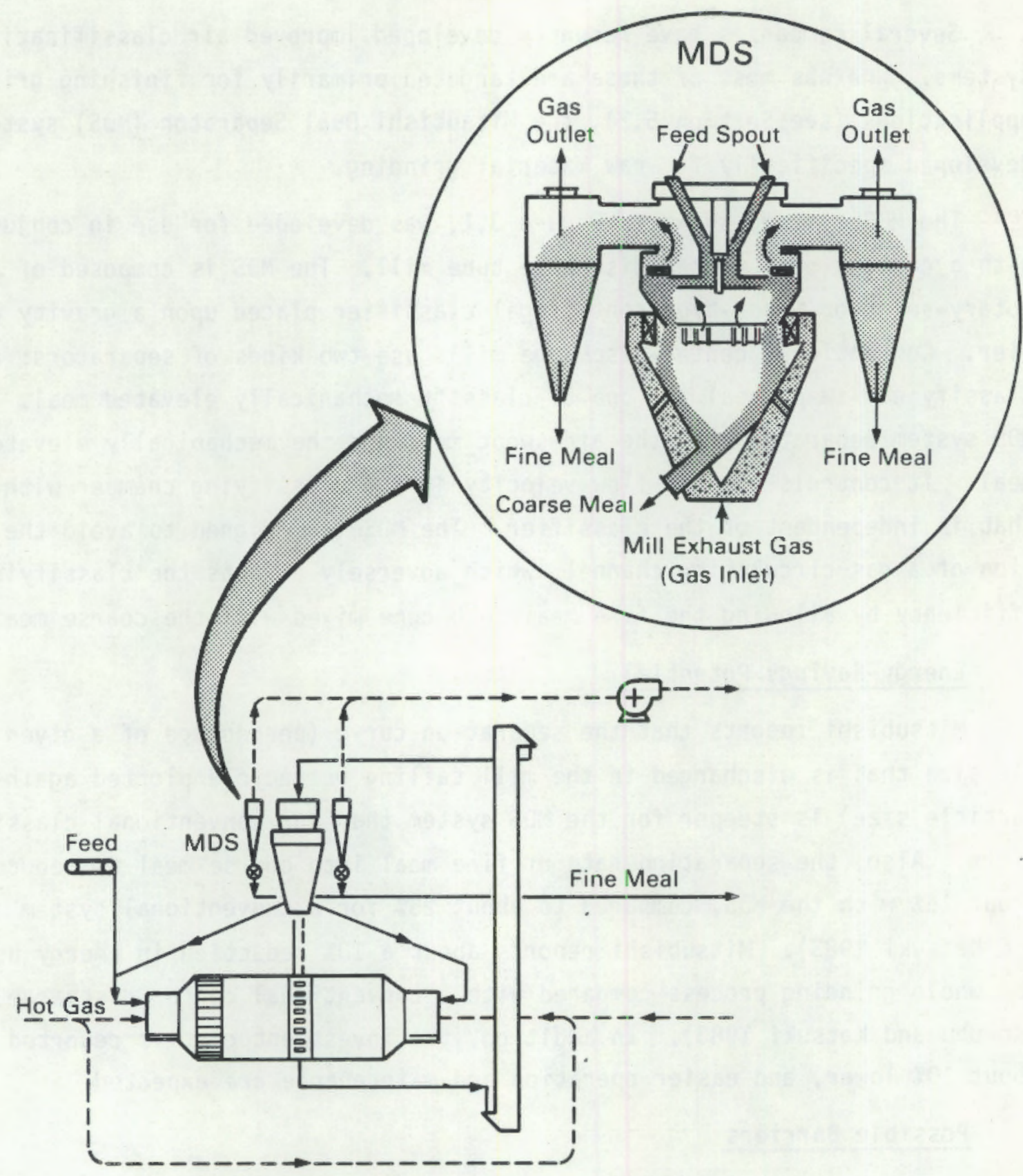

FIGURE 3.1. Mitsubishi Dual Separator (Kokubu and Katsuki 1983)

undertaken at the Central Testing and Research Department, Cementir in Naples, Italy, have shown that the reactivity of the raw meal is influenced by the relative fineness of single components within the mix. Laboratory tests indicate that the relative grain sizes of the limestone and the clay materials have 
a marked influence on the rate of the solid-state reactions. Solid-state reactions, which occur from about $1000^{\circ} \mathrm{F}$ to $2300^{\circ} \mathrm{F}$, involve the uptake of Time (CaO) by the oxide $\left(\mathrm{SiO}_{2}, \mathrm{Fe}_{2} \mathrm{O}_{3}\right.$ and $\left.\mathrm{Al}_{2} \mathrm{O}_{3}\right)$ granules. The tests concluded that a greater fineness of clay as compared with that of limestone increases the reaction rate (reduces the temperature needed to initiate the reaction).

\section{Energy-Savings Potential}

From the Cementir tests, it was concluded that it would be possible to save energy in pyroprocessing if the limestone and clay are ground separately, so that for the same grinding energy, the clay has a higher fineness than that of the 1-mestone (Frigione, Zenone and Esposito 1983). No estimate of the amount of energy that could be saved was made from these tests. However, the PCA has estimated that the energy required for raw material grinding could be reduced as much as $10 \%$ by grinding the hardest portion of the mix separately from the rest of the mix (PCA 1975). Allis-Chalmers recommends that silica be ground separately from the other raw materials. (a)

\section{Possible Barriers}

The major near-term barrier to adopting this technology is the lack of demonstrated energy savings in an actual installation. Separate grinding of raw materials represents a radical departure from current raw material preparation practices, which achieve a substantial degree of homogenization of the raw material before it enters the raw grinding mill. Grinding the materiais separately may involve additional operating costs for proportioning and blending the raw materials after grinding.

\subsubsection{Grinding Media and Mill Lining}

Grirding operations are complex in that many factors affect power consumption. Currently, actual grinding mechanisms are not sufficiently understood to base mill design and operation on anything other than long-established empirical relationships derived from successful past experience. Grinding media and mill lining material are usually selected according to the wear characteristics

(a) Personal communication with Thomas Brown, Allis-Chalmers, Milwaukee, Wisconsin. 
of the material because these characteristics affect replacement costs. However, increases in the specific gravity and surface hardness of grinding media and wear-resistant mill linings have reportedly shown significant potential for reducing grinding energy use (Mclvor 1983).

The effect of lining wear on power consumption is particularly dramatic in smaller diameter mills. For example, 2 inches of liner wear results in about a $14 \%$ increase in power consumption in an 8-ft diameter mill and about a $6 \%$ increase in a 16.5-ft diameter mill (McIvor 1983). Insufficient information is available to determine the potential energy savings due to alternative grinding media and mill-liner materials.

\section{1 .6 Sensors and Controls}

Computer control of grinding circuits using analog systems and data loggers is well established. The next generation of control systems for optimizing the performance of wet and dry mills is expected to be an extension of di rect digital computer control.

Grinding circuits are continually faced with changes in feed characteristics that cause the operating conditions to deviate from optimal design conditions. The frequency of these deviations and the response time and reliability of manual operation make computerized control systems particularly attractive for optimizing grinding operations.

\section{Energy-Savings Potential}

Energy efficiency improvements of up to $15 \%$ have been reported with automatic control systems.

Potential Barriers

Capital constraints and lack of operating experience are seen as the major barriers to adopting computerized control.

\subsection{SLURRY DEWATERING}

Typical wet process slurries contain about $62 \%$ solids and $38 \%$ water (Sapp 1981). Between $20 \%$ and $25 \%$ of the process heat required in the wet process is 
used to evaporate the water from the slurry. Dewatering the slurry offers considerable potential for energy savings. Slurry filters or slurry thinners are used in dewatering.

\subsubsection{Surry Filters}

In the 1940s, disc- and drum-type filters were commonly used in the U.S. cement industry. These filters could reduce the water content to about $20 \%$. However, these systems were abandoned as the labor costs associated with their use rapidly outpaced the fuel costs associated with evaporating the additional water from the feed. Today, filter presses are widely used in Europe to reduce slurry moisture to about $20 \%$ (Labahn and Kohlhaas 1983). A pelletized feed is then extruded that can be fed directly to the kiln or used with a grate preheater.

\subsubsection{Siurry Thinners}

Surface-active agents can be used to replace water in feed slurries. Slurry thinners react differently with various feed compositions, so each must je evaluated individually. Common slurry thinners include polyphosphates, lignosites, and soda ash. Tests conducted at the Genstar Cement Ltd. wet process plant in Edmonton, Alberta, indicated that $0.58 \times 10^{6} \mathrm{Btu} /$ ton of clinker could be saved by using sodium polyacrylate to reduce the water content of the slurry from $35.8 \%$ to $29 \%$ (Lokanc 1983).

\subsection{FEED MATERIAL DRYING}

According to the PCA (1975), between 36,000 and 54,000 Btu/ton of clinker are requ red per percent of moisture content to dry raw materials. Two technologies for reducing the energy used for drying raw materials are waste heat drying and fluidized-bed drying.

\subsubsection{Waste Heat Drying}

Low-grade waste heat is available from efficient dry process systems (both preheater and precalciner systems). Probably the most practical near-term use of this heat is for drying raw materials or coal. Although many plants have 
taken advantage of this heat source, many others still operate separate fuelfired dryers. The waste heat can be use in air-swept mills such as roller mills or in compartmented ball mills.

Currently about $3 \%$ of the total fuel burned by the cement industry is used for drying raw materials and coal. If waste heat completely replaces fuelfired dryers, an annual energy savings of about $8.5 \times 10^{12}$ Btu could be realized at 1982 production levels.

To use the waste heat for drying, the grinding operation must be located near the waste heat source. Existing plant layou:s may act as a barrier to this energy-saving technology. Using waste heat for drying may allow alkalis to become concentrated in the mill.

\subsubsection{Fluidized-Bed Drying}

Babcock Worsley, in collaboration with the United Kingdom National Coal Board, has developed a coal-fired fluidized bed (FB) furnace for drying applications. Thirteen Babcock Worsley FB furnaces were installed between 1975 and 1978 for drying agricultural products for animal feed. Success with these installations led to the development of a furnace for raw material and fuel drying for the cement industry. The first installation for raw material drying consisted of two $25 \mathrm{Btu} / \mathrm{hr}$ FB furnaces supplying hot gases (up to $1560^{\circ} \mathrm{F}$ ) to a clay dryer/crusher at the Ketton Portland Cement Company, England. Installations for both raw material and coal drying are now operating in Denmark, West Germany, and Wales, as well as several other sites in England.

The Babcock Worsley FB furnace consists of a refractory-lined combustion chamber containing silica sand at a static depth of about six inches. The furnace is designed to use any type of coal as well as waste materials, such as refuse-derived fuels and process residues. This "lexibility in fuel use is possible because the fluidized bed is more amenable to automation than a mechanical stoker. The pulverized fuel is metered by a screw or rotary valve onto the bed surface where it is distributed by the turbulence, ensuring a unifom bed temperature. The fuel feed rate is controlled automatically to maintain the required bed temperature. In most cases, the hot gases are drawn through the drying operation by an induced-draft fian. 
Furnace startup is fully automatic and takes about 30 or 40 minutes. An external oil- or gas-fired burner is used to preheat the fluidizing air to about $1300^{\circ} \mathrm{F}$. The hot gases preheat the sand bed to about $1000^{\circ} \mathrm{F}$ before fuel is fed to the bed. After combustion is established in the furnace, the preheating burner is automatically shut of $f$ and the bed is gradually increased to its operating temperature by controlling the fuel feed rate (Golden 1984).

The output of existing furnaces ranges from 0.9 to $15 \mathrm{MW}$, with the largest installation to date having two $7.5 \mathrm{MW}$ furnaces. Typical operating conditions are as follows (Golden 1984):

Excess Air Level: 150\%

Fluidizing Velocity: $8.2 \mathrm{ft} / \mathrm{s}$

Bed Temperature: $1475^{\circ} \mathrm{F}$ to $1750^{\circ} \mathrm{F}$

Hot Gas Temperature: $1900^{\circ} \mathrm{F}$.

Babcock Worsley and the National Coal Board are now working to increase the heat output of the furnaces to produce gases in excess of $2375^{\circ} \mathrm{F}$ and to reduce the ash carryover to achieve clean and semi-clean hot air.

Energy-Savings Potential

The Babcock Worsley FB furnace is reported to be particularly suited to installations where process exhaust gases are not available and where slight contamination of the product with fly ash can be tolerated (Golden 1984). Because the furnace can burn waste fuels, the higher-grade fuels can be saved for alternative uses.

About $3 \%$ of the annual fuel use of the cement industry is for raw material and fuel drying (about $8.5 \times 10^{12}$ Btu in 1982). Thus, this represents the maximum potential savings of high-grade fuels that could be achieved if this technolouy were implemented $100 \%$.

Possible Barriers

The lack of experience with fluidized-bed technology by the U.S. cement industry and the lack of investment capital are the major barriers to adopting this technology. The effects of burning waste fuels on air quality must be analyzed to ensure conformance with Environmental Protection Agency standards and public acceptance of the use of waste fuels must be considered. 
,

. 


\subsection{PYROPROCESSING}

The objective of this chapter is to assess the energy-savings potential of technologies that modify existing pyroprocessing equipment to improve therma performance (i.e., the energy use per ton of clinker is reduced). The technologies that are discussed include the following:

- wet-to-dry conversion

- advanced kiln control

- redsced radiation and infiltration

- advanced kiln systems

- catalyzed, low-temperature calcination

- internal heat-transfer enhancement

- alkzli specification modification.

\subsection{WET-TO-DRY CONVERSION}

Dry process technologies offer proven, energy-efficient alternatives to the wet irocess. This section discusses the conversion of a wet process kiln to one o* the following: 1) long-dry kiln, 2) preheater $k i l n$, or 3) preneater/precalciner kiln.

In converting from the wet process to a dry process, the existing wet $k i$ in can be shut down and replaced with a new dry process kiln, or the existing wet process kiln can be used in the conversion. If the existing kiln is used, its length would be shortened for the preheater or precalciner processes, whereas the entire length would be used for the long-dry process. The three dry processes are briefly discussed below.

\subsubsection{Long-Dry Kilns}

The long-dry kiln is simply a rotary kiln that uses dry raw materials in the clinkering process. With this kiln, the need for an evaporation section, which is used in the wet process, is eliminated. Eliminating the evaporation section allows the dry process kiln to be shorter than a wet process kiln, or to have a greater throughput at the same length. 


\subsubsection{Preheater Kilns}

Compared to the wet process or the long-dry process, preheater systems have major potential for fuel savings. Preheaters also significantly increase the capacity of a single kiln system by calcining up to $50 \%$ of the feed before it enters the $k i l n$.

There are two basic types of preheater systens: the grate-type preheater and the suspension (cyclone) preheater. Both types are installed external to the kiln at the feed end and act to enhance the contact between the waste combustion gases and the feed material.

Grate preheaters consist of a travelling grate carrying a bed of pelletized raw materials. In either a single-pass or double-pass, the hot kiln gases flow through the bed of pellets on the grate. This method of cement manufacture is referred to as the Lepol process, and the preheaters are referred to as Lepol grates.

Suspension preheaters (SP) provide intimate contact of the incoming feed with the kiln exhaust gases in a cyclone arrangement. Between $40 \%$ and $50 \%$ of feed calcination occurs in the suspension preheater (Garrett 1980). The first commercial installation with a cyclone preheater was built by Humboldt of Germany in 1953. Humboldt was the sole supplier of cyclone preheaters until 1959. Figure 4.1 shows an example of a four-stage preheater developed by Humboldt (one to five cyclones have been used). Other firms (see Table 4.1) have since developed their own versions of the cyclone preheater. With the exception of the Krupp system, the basic operation of each of the systems is the same. The difference occurs in the number of feed points and cyclones, and the arrangement of the cyclones. In the Krupp system; a pair of cyclones receives the feed in parallel. Connected to the cyclones is a tower in which the feed flows by gravity to the kiln.

Although the SP process uses more electricity per ton of product than the wet process, development work is proceeding on low-pressure-drop cyclones for preheater systems. These will reduce fan power requirements and reduce the size of the preheater tower, thereby lowering both the operating and the capital costs of the system. 


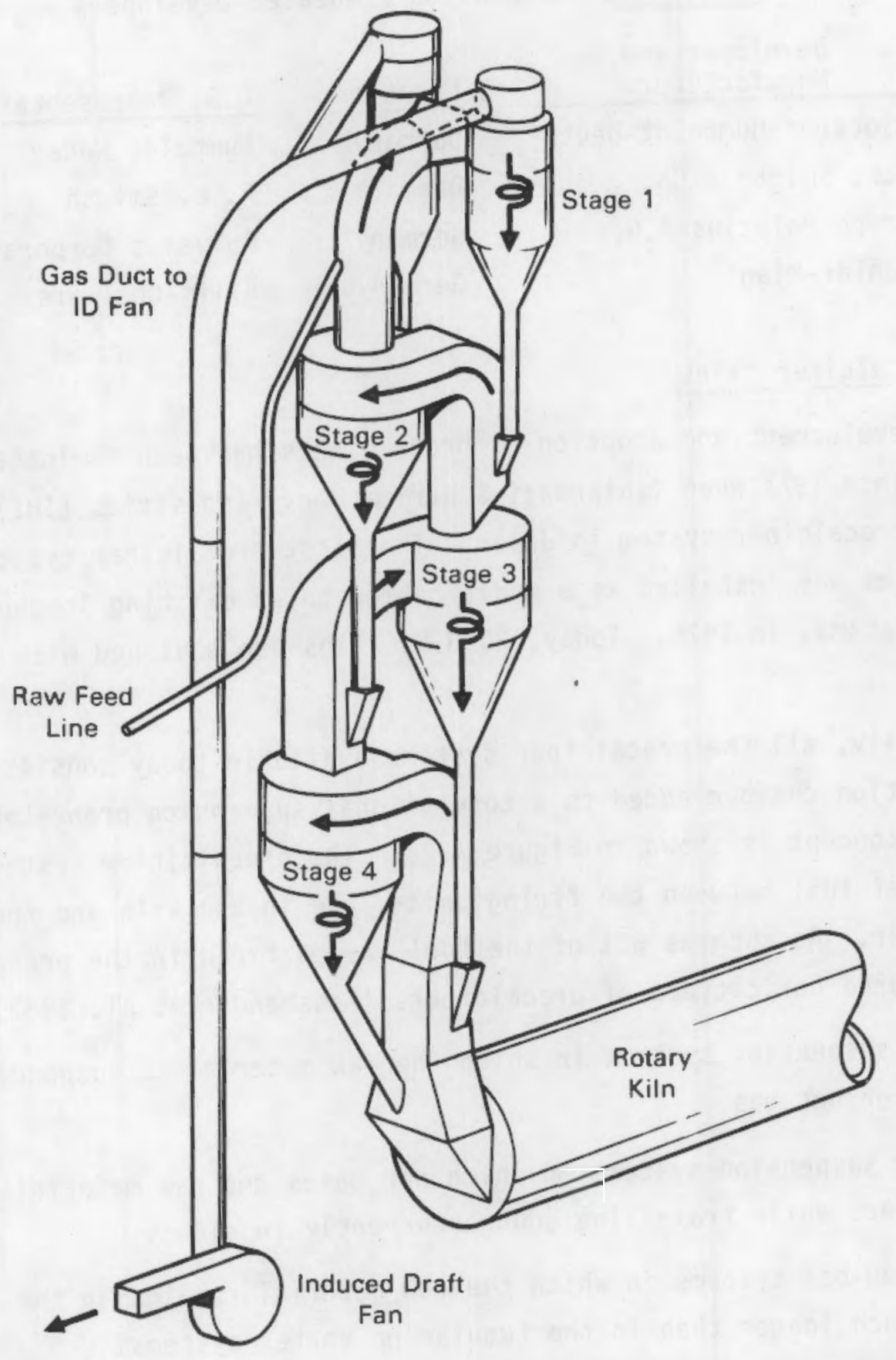

FIGURE 4.1. Fuller-Humboldt Four-Stage Suspension Preheater 
TABLE 4.1. Suspension Preheater Developers

\begin{tabular}{|c|c|c|}
\hline $\begin{array}{l}\text { Developer and } \\
\text { Manufacturer }\end{array}$ & Location & U.S. Representative \\
\hline Klockner-Humboldt-Deutz & Germany & Humboldt Wedag \\
\hline F.L. Smidth \& Co. & Denmark & F. L. Smidth \\
\hline Krupp Polysius A.G. & Germany & Polysius Corporation \\
\hline Buhler-Miag & Germany & Allis-Chalmers \\
\hline
\end{tabular}

\subsubsection{Precalciner Kilns}

The development and adoption of precalciners has been dominated by the Japanese since 1971 when Ishikawajima Harima Heavy Industries (IHI) installed the first precalciner system in Japan. The first precalciner system in the United States was installed as a modification to an existing long-dry kiln at Ragland, Alabama, in 1976. Today, 20 U.S. kilns are equipped with precalciners (PCA 1984).

Basically, all the precalciner systems available today consist of a separate combustion chamber added to a conventional suspension preheater system. (The basic concept is shown in Figure 4.2). The precalcining system divides the supply of fuel between two firing units, one in the kiln and the other in the preheater. As much as $60 \%$ of the fuel may be fired in the precalciner. There are three basic types of precalciners (Fassbender et al. 1982):

- vortex suspension systems in which the raw material is suspended in a vortex of hot gas

- tubular suspension systems in which hot gases and raw materials are in contact while travelling countercurrently in a duct

- fluidized-bed systems in which the raw material remains in the calciner much longer than in the tubular or vortex systems.

An example of each is shown in Figure 4.3 .

Most precalciners are vortex suspension systems. In a vortex precalciner, the raw material particles are suspended in the gas flow at the lower part of the chamber, where atomized or pulverized fuel particles are introduced through multiple burners. As the fuel burns, heat is transferred directly to the raw 


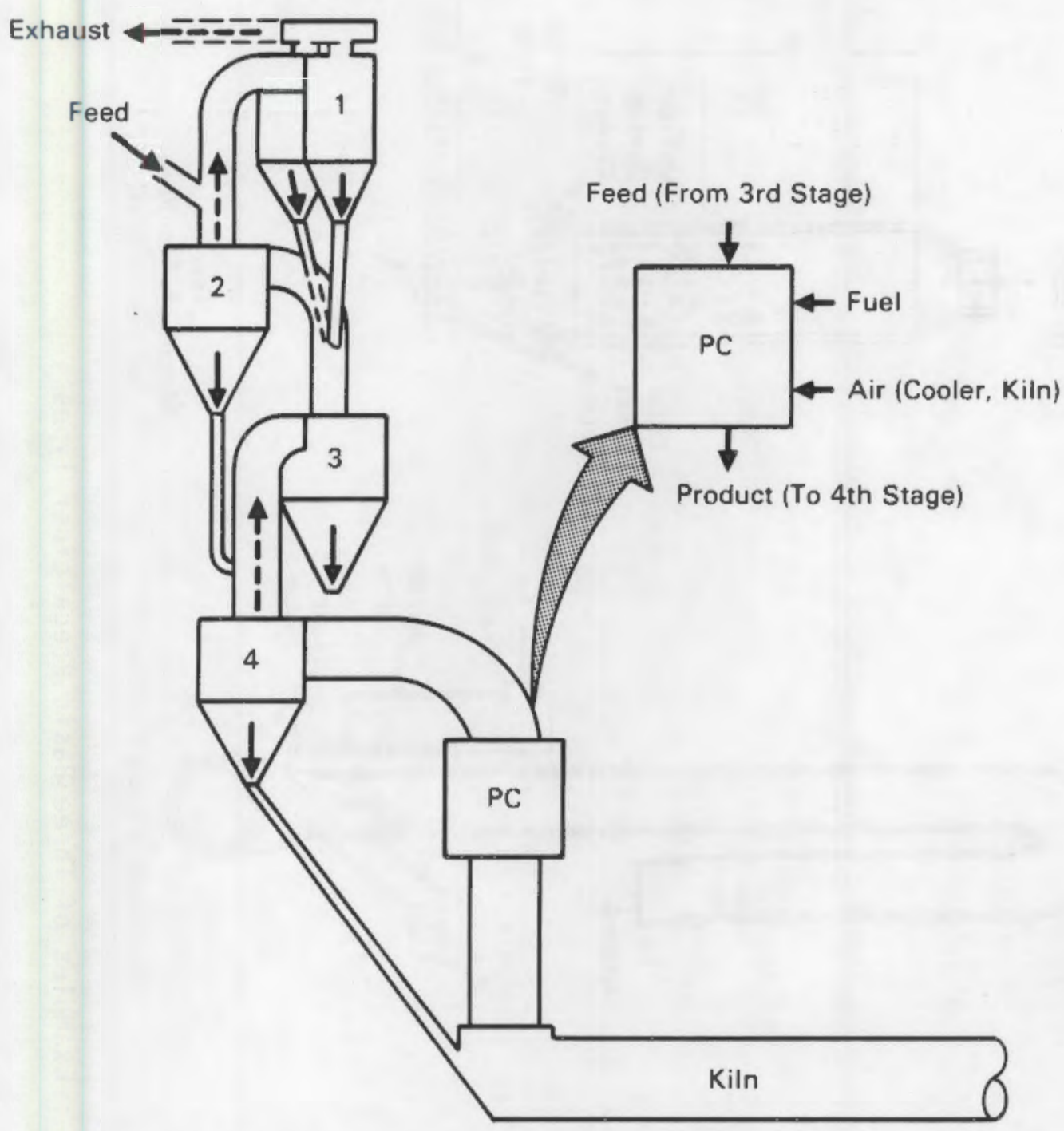

FIGURE 4.2. Precalcining Concept (Howlett, and Garrett 1981)

material and calcination is accomplished. The combustion gases and the feed rise and are discharged from the flash calcining chamber to the lowest stage of the preheater.

Several advantages of precalciner systems compared to the suspension preheater process have been noted by Howlett and Garrett (1981). These advantages include 1) a capacity increase of more than a factor of two, 2) increased refractory life in the burning zone of about 4 to 1,3 ) improved kiln system availability of up to $10 \%, 4)$ concentration of alkali, sulfur, and chlorine 


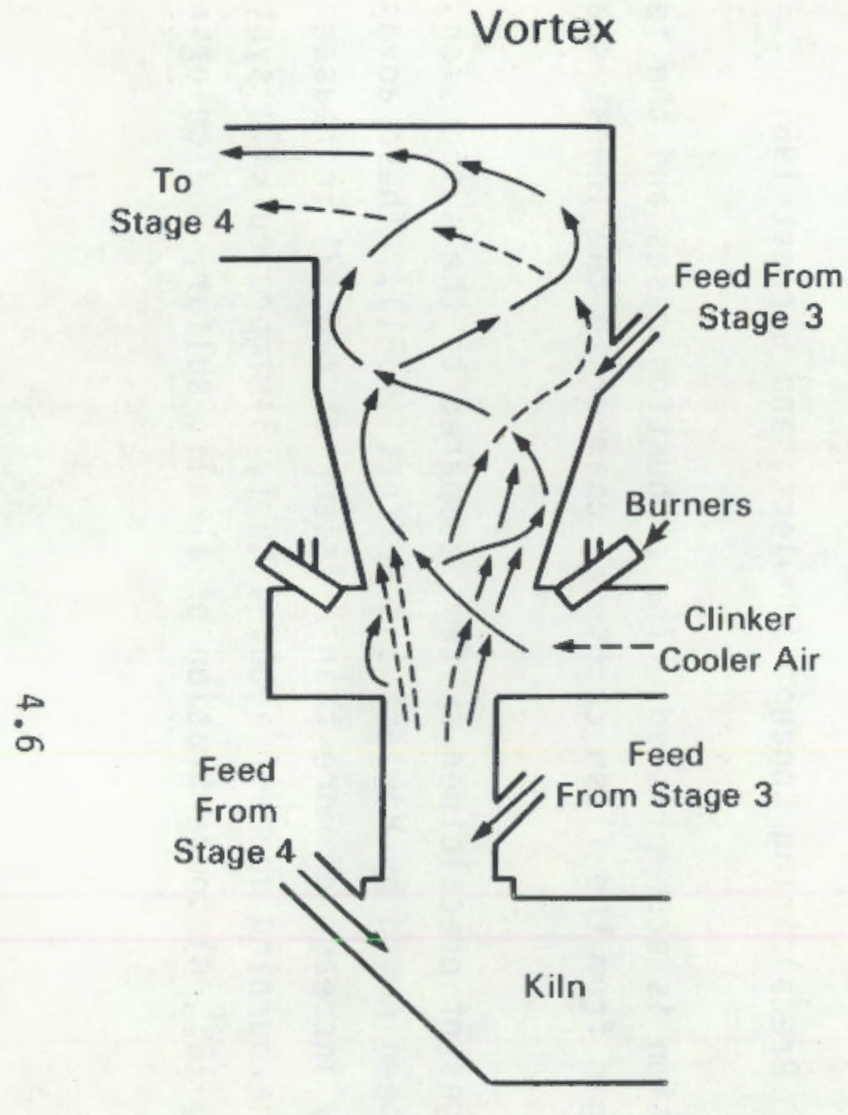

Kawasaki Heavy Ind. New Suspension Flash (NSF)

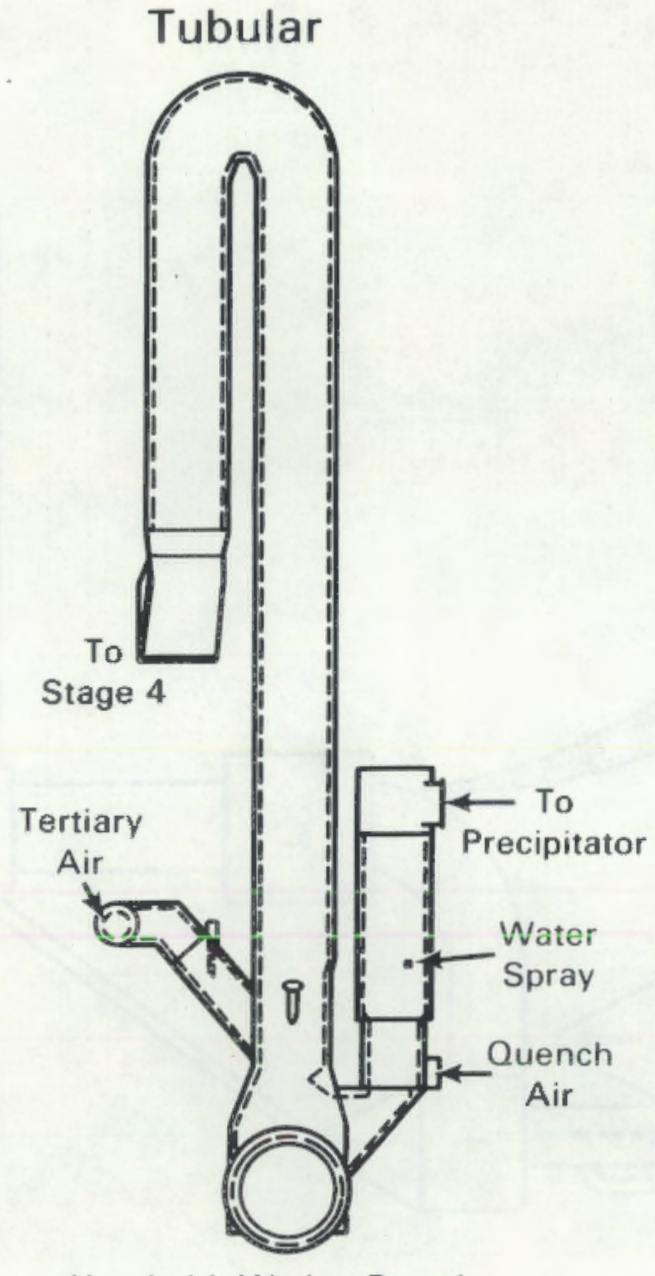

Humboldt Wedag-Pyroclon

\section{Fluidized Bed}

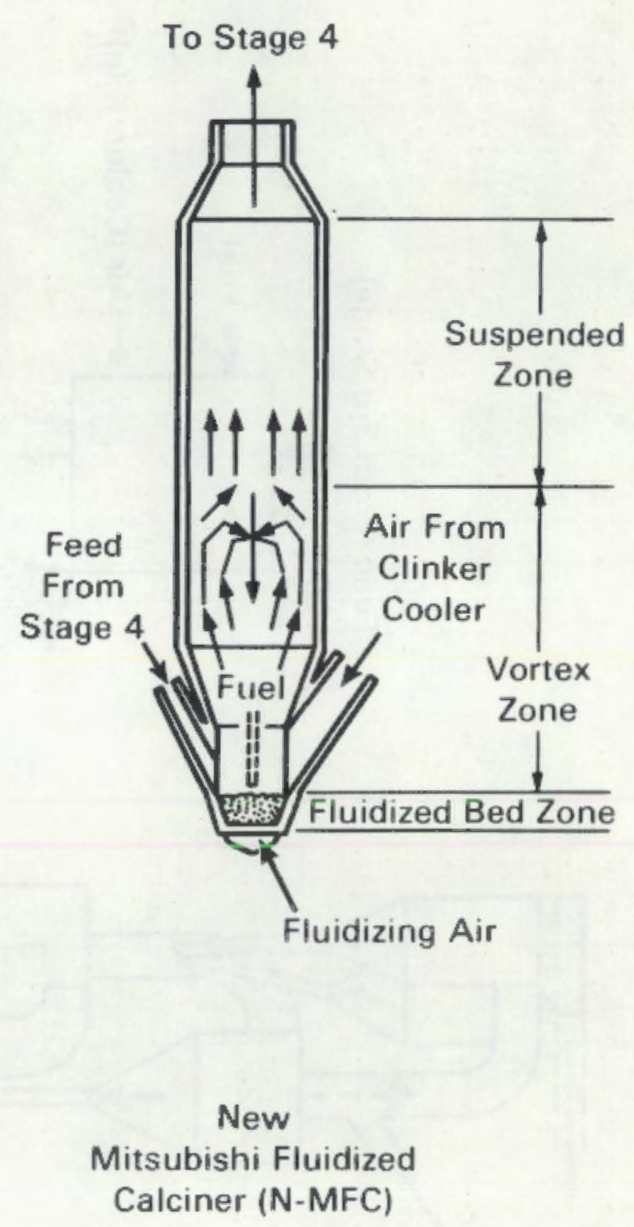

FIGURE 4.3. Examples of Three Basic Precalciner Types 
fumes in about one-third the volume of exit gas, 5) a $50 \%$ reduction in $\mathrm{NO}_{\mathrm{x}}$ generation, 6) allowance for up to $60 \%$ use of waste fuels, 7) two-fold reduction of condensate buildups, 8) improved potential for automation, 9) improved operating stability, 10) generally lower operating costs, and 11) a small reduction in fuel consumption (relative to the preheater).

\subsubsection{Energy-Savings Potential}

Each of the dry process technologies is significantly more fuel-efficient than the wet process. Table 4.2 compares the heat balances of efficient wet and dry process kilns. The most significant advantage of the dry processes is that thes virtually eliminate the need for evaporating water from the feed. Another najor difference is that shell radiation and convection losses are reduced. These losses are reduced because the dry process kiln is much shorter, again due to the elimination of the evaporation section. The radiative and convective losses associated with the dry processes decline as the amount of calcining that occurs in the kiln declines (100\% in the long-dry

TABLE 4.2. Heat Balance Comparison of Efficient Wet and Dry Processes (million Btu/ton of clinker) (Adapted from PCA 1975)

\begin{tabular}{|c|c|c|c|c|}
\hline & \multirow[b]{2}{*}{ Wet } & \multicolumn{3}{|c|}{ Dry } \\
\hline & & Long Kiln & Suspension Preheater & Precalciner \\
\hline \multicolumn{5}{|l|}{ Heat Supplied } \\
\hline Fuel & 5.414 & 3.941 & 2.901 & 2.730 \\
\hline Raw Mix & 0.072 & 0.048 & 0.048 & 0.048 \\
\hline Air & 0.014 & 0.043 & -- & --- \\
\hline Total & 5.500 & 4.032 & 2.949 & 2.778 \\
\hline \multicolumn{5}{|l|}{ Heat Required } \\
\hline Clinker Formation & 1.523 & 1.523 & 1.523 & 1.523 \\
\hline Clinker Sensible & 0.040 & 0.056 & 0.072 & 0.086 \\
\hline Excess Air & 0.137 & $0.30 B$ & 0.390 & 0.350 \\
\hline Water Evaporation & 2.206 & 0.022 & 0.022 & 0.022 \\
\hline Exhaust. Gas & 0.694 & 1.339 & 0.631 & 0.572 \\
\hline Dust & --- & 0.200 & 0.022 & 0.011 \\
\hline Radiation and Convection & 0.900 & 0.584 & $\underline{0.289}$ & 0.214 \\
\hline Total & 5.500 & 4.032 & 2.949 & 2.778 \\
\hline
\end{tabular}


process, $60 \%$ in the preheater process, and $10 \%$ in the precalciner process). The ratio of the surface area of the kiln to the throughput dectines in each case, thus reducing the heat-transfer area. Also, because the equipment is stationary, radiation losses can be reduced in preheaters and precalciners through the optimal choice of refractories and insulation.

The fuel-savings potential of converting to each of the dry processes is summarized in Table 4.3 and is discussed below.

TABLE 4.3. Fuel-Savings Potential of Dry Process Kilns Relative to the Wet Process

\begin{tabular}{|c|c|c|c|}
\hline & $\begin{array}{l}\text { Unit Savings } \\
\left(10^{6} \text { Btu/ton }\right) \\
\end{array}$ & $\begin{array}{c}\text { Tota } \\
\left(10^{12} \text { Savings }\right. \\
\text { Btu }\end{array}$ & $\begin{array}{l}\text { Fuel Saved as } \\
\text { a Percent of } \\
1982 \text { Fuel Use }\end{array}$ \\
\hline Long-Dry & 0.5 & 12.6 & 4 \\
\hline Preheater & 1.7 & 59.6 & 16 \\
\hline Precalciner & 1.9 & 70.7 & 20 \\
\hline
\end{tabular}

(a) Based on 1982 production levels.

Long-dry kiln systems, on an average, consumed about 0.5 million Btu per ton of clinker less than wet systems in 1982. Converting all existing wet kiln capacity (25.3 million tons equivalent in 1982) to dry capacity would result in an average annual fuel savings of about $12.6 \times 10^{\text {l2 }}$ Btu of energy at 1982 production levels. This would represent about a $4 \%$ savings in energy consumption at 1982 levels.

The suspension preheater used an average of 1.7 million Btu/ton of cement less than the wet process and 1.2 million Btu/ton of cement less than the longdry process. If all existing wet and long-dry capacity could be converted to the suspension preheater system, an annual savings of about $59.6 \times 10^{12}$ Btu could be realized at 1982 production levels. This represents an energy savings of $16 \%$.

If the energy efficiency of a precalciner system is assumed to be $3 \%$ to $6 \%$ better than a preheater system (Howlett and Garre:t 1981), then converting the remaining capacity that does not currently use precalciners to this system 
would save an average of 1.3 million Btu/ton of cement. That is, the precalciner process would save the following relative to the other three processes:

\begin{tabular}{lc} 
& \multicolumn{2}{c}{ Million Btu/ton Cement } \\
Saved by Adopting Precalciner
\end{tabular}

Thus, if all cement capacity is converted to the precalciner process, about $70.7 \times 11^{12}$ Btu would be saved at 1982 production levels. This represents a savings of $20 \%$.

\subsubsection{Possible Barriers}

The greatest barrier to converting wet process capacity to any of the dry processes is economic. The industry has insufficient capital to re-invest in new equipment as a result of low profits steming from a sluggish construction industry in recent years.

Another barrier is that the physical properties of some of the raw materials mav make dry grinding methods technically impossible. Some sources of raw materials would have to be abandoned if dry-process conversion was to be all-encompassing. Redfern (1983) predicts that within the next 25 years, only cement plants used for hazardous waste disposal will continue with the wet process; all others will be dry or semi-dry.

Additional technical barriers to adopting suspension preheaters include the following (PCA 1975; Biege, and Parsons 1978):

- Raw materials with high alkali content require the use of substantial preheater bypass in order not to exceed product specifications.

- Raw materials containing kerogens (oil shale) cannot be used with the preheater process.

- Some? feed or fuel constituents, such as high levels of alkalies, chlorides, fluorides, and sulfur, may cause preheater plugging. 


\subsubsection{Economics of $\mathrm{Kiln}$ Conversion}

The cost of converting from the wet to dry process, using some of the existing equipment, was found to range from $\$ 40$ tc $\$ 65 /$ ton of capacity. The cost of new preheater or precalciner plants ranges from $\$ 85$ to $\$ 140 /$ ton of capacity (Kreisberg and Schonbach 1983). Converting all existing wet capacity to dry capacity would cost almost $\$ 2$ billion at an assumed conversion cost of $\$ 55 /$ ton. Because cement shipments in 1982 were valued at $\$ 3.5$ billion, the amount of capital available for re-investing in new equipment clearly is low compared with the estimated amount needed to convert to the dry process.

In general, it is not economical to use the wet process kiln when converting to the long-dry process. The slight increase in efficiency and production do not offset the cost of modifications that must be made to the raw grinding and homogenization systems (Kreisberg and Schonbach 1983). Kreisberg and Schonbach conducted six case studies on converting wet processes to dry processes conversion. The results of those studies are shown in Table 4.4 .

\subsection{ADVANCED KILN SYSTEMS}

This section discusses several advanced $k i l n$ systems, including several stationary calcining systems and all-electric or electric/fossil kilns.

\subsubsection{Stationary Calcining Systems}

Both domestic and foreign firms are continuing to modify preheater/ precalciner designs. The general trend in pyroprocessing systems is toward shorter kilns, with more of the calcining occurring in stationary precalcining equipment. This trend has led some to speculate that eventually the rotary kiln will disappear entirely and that pyroprocess"ng will be accomplished entirely in stationary equipment.

Stationary fluid-bed reactors offer several potential advantages over the rotary kiln (Wilson 1984):

- the opportunity to reduce radiation losses through the optimal choice of refractory and insulating materials

- the opportunity to use automatic process control 
TABLE 4.4. Case Studies of Wet Process to Ury Process Conversion (Kreisberg and Schonbach 1983)

\begin{tabular}{|c|c|c|c|c|c|c|}
\hline Case & 1 & 2 & 3 & 4 & 5 & 6 \\
\hline \multicolumn{7}{|l|}{ Prodiurtion (tons/yr) } \\
\hline Wet & 300,000 & 300,000 & 600,000 & 600,000 & 300,000 & 600,000 \\
\hline Dry & $1,000,000$ & 600,000 & $1,000,000$ & 600,000 & 650,000 & 650,000 \\
\hline $\begin{array}{l}\text { Number of wet } \\
\text { Kilns Replaced }\end{array}$ & 1 & 1 & 2 & 2 & 1 & 2 \\
\hline $\begin{array}{l}\text { Type of Dry } \\
\text { Process }\end{array}$ & New SF & New SP/SF & New SF & New SP/SF & Convert SF & Convert \\
\hline \multicolumn{7}{|l|}{$\begin{array}{l}\text { Heat Consumption } \\
\text { (MMBtu/ton) }\end{array}$} \\
\hline Wet & 5.934 & 5.934 & 5.934 & 5.934 & 5.934 & 5.934 \\
\hline Dry & 2.900 & 3.000 & 2.900 & 3.000 & 3.100 & 3.100 \\
\hline \multicolumn{7}{|l|}{$\begin{array}{l}\text { Power Consumption } \\
\text { (kwh/ton) }\end{array}$} \\
\hline Wet & 138 & 138 & 138 & 138 & 138 & 138 \\
\hline Dry & 125 & 125 & 125 & 125 & 143 & 143 \\
\hline \multicolumn{7}{|l|}{$\begin{array}{l}\text { Labor Force } \\
\text { (\# Personnel) }\end{array}$} \\
\hline Wet & 140 & 140 & 150 & 150 & 140 & 150 \\
\hline Dry & 120 & 120 & 120 & 120 & $14 b$ & 145 \\
\hline \multicolumn{7}{|l|}{$\begin{array}{l}\text { Cost of Conversion } \\
(\$ / \text { ton capacity })\end{array}$} \\
\hline Typical & $85-115$ & $105-140$ & $85-115$ & $105-140$ & $40-65$ & $40-65$ \\
\hline Value Used & 110 & 135 & 110 & 135 & 60 & 55 \\
\hline $\begin{aligned} S P & =\text { suspension } \\
S F & =\text { suspension } \\
\text { SP/SF } & =\text { suspension }\end{aligned}$ & $\begin{array}{l}\text { preheater. } \\
\text { preheater w } \\
\text { preheater or }\end{array}$ & $\begin{array}{l}\text { precalci } \\
\text { uspension }\end{array}$ & - & $\rho$ & & \\
\hline
\end{tabular}


- uniformity of operation and of product qualit:y

- decreased maintenance costs

- an increase in annual operating hours.

Several stationary pyroprocessing systems were conceptualized and patented in the early seventies, but none have been commercially applied to date. PCA (1975) provided a good overview of four of these systems:

- a trough kiln concept patented by Thermo Electron Corporation, Waltham, Massachusetts

- the Harrop Osciplate Calciner by the Harrop Ceramic Service Company of Columbus, Ohio

- the Linde Swirl Burner patented by the Union Carbide Corporation

- the Pyzel Fluid Bed developed by the Fuller Corporation and later improved by Scientific Design Company, New York.

Recently, a new modification to the fluid bed kiln has been conceptualized by Bendy Engineering, Cleveland, Ohio. Each of these stationary kiln concepts are discussed below.

Thermo Electron Trough Kiln

The Thermo Electron trough kiln system was patented on May 28, 1974. Initial, smal1-scale, proof-of-concept experiments were conducted by Kaiser Engineers. However, Thermo Electron reports that because Japanese precalciner technology was being commercialized when Thermo Election was beginning development work on the trough kiln, development funds were withdrawn because they could not compete with a commercialized process. (a) The fuel-energy requirement for this process is reported to be about 2.79 million Btu/ton of clinker (PCA 1975).

(a) Description of Thermo Election trough xiln obtained through telephone conversation with Gabor McCloskey, Thermo Election, Waltham, MA. 
Harrop Osciplate Calciner ${ }^{m}(a)$

The osciplate ${ }^{\text {m }}$ is a continuous calciner in which a bed of material moves over a series of stationary, overlapping hearths. The modular hearths are in a stair-step arrangement. The material is conveyed by oscillating pusher plates powered by hydraulic cylinders. The oscillating frequency of the pusher plates is adjusted to control the volume of material in the calciner (Harrop Industries, Inc. undated).

Harrop Ceramic Service Company reports that although the Osciplate is not yet to the design stage where commercial production of cement is feasible, development is continuing. The company does not consider the osciplate viable for cement production at this time because of limitations in process temperature and capacity. The maximum achievable temperature is currently $1400^{\circ} \mathrm{C}$ $\left(2552^{\circ} \mathrm{F}\right)$ with their largest calciner. The largest calciner, sized in terms of hearth surface area, has $100 \mathrm{sq}$. ft. of hearth.(b)

\section{Linde Swirl Burner}

In a telephone conversation, Union Carbide staff indicated that this conceptual system was not developed beyond the patent stage because the economics did not appear favorable. In this system, a conical reactor vessel replaces the conventional rotary kiln for clinkering. Precalcined feed enters the clinker reactor just above the inlet for the fuel and air stream. The gas stream fluidizes the feed, and clinkering occurs rapidly. The reactor is designed to maximize heat exchange between the combustion gases and the feed material. The combustion gases from the reactor can be used in the preheater or wasted, depending on the level of alkati, sulfur, and chlorine that must be removed. This system reportedly can reduce energy requirements by $0.15 \mathrm{milli}$ in Btu/ton of clinker compared to a suspension preheater using $3.5 \mathrm{million} B$ Btu/ton (PCA 197j).

(a) Trademark of Harrop Industries, Inc., Columbus, Ohio.

(b) Description of the osciplate obtained through telephone conversation with Daniel 0'Brien, Harrop Industries, Inc., Columbus, Ohio. 


\section{Modified Fluid-Bed Processes}

Pilot plant work conducted 20 years ago demoristrated that fluidized-bed technology can be used to produce portland cement clinker. However, the original fluid-bed kiln design (Pyzel kiln) required excessive heat input because it performed both the calcining and the sintering in the same vessel, and the sensible heat in the clinker and in the exhaust gases was wasted (Wilson 1984). Two modified designs, which recover the waste heat, are described below.

Scientific Design Company. (a) Scientific Design Company (SDC) of New York has modified the original Pyzel kiln to recover heat for steam generation and subsequent power production. Experiments were conducted with a 100-ton/day fluid-bed pilot plant to demonstrate the heat recovery aspects of the process. SDC feels that the fluid bed has several advantages compared to the rotary kiln, including the following: 1) any fue can be burned; 2) it generates little dust; and 3) it can use high-alkali kiln dust that has accumulated at cement plants as a feed material.

According to SDC, Israeli cement companies were considering using the fluid bed in order to use oil marl resources but were prevented from doing so by an economic downturn. SDC also reports that Blue Circle Cement in England was close to adopting this process at one point because it was faced with tightened restrictions on landfilling its kiln dust. However, an economic downturn, followed by easing of the landfill restrictions, prevented its implementation. SDC feels that no further development work is needed on the system and that the barriers to its implementation are economic and political, rather than technical. The SDC design is available for license.

Bendy Engineering. The conceptual fluidized-bed process developed by Bendy Engineering (Figure 4.4) provides a way to recover the sensible heat from the clinker and from the exhaust gases. The fluid-bed sintering reactor is preceded by a conventional suspension preheater with a precalciner. The raw

(a) Information on Scientific Design Company obtained through a telephone with Ronald Cascone, Scientific Design Company, New York, and through personal correspondence. 


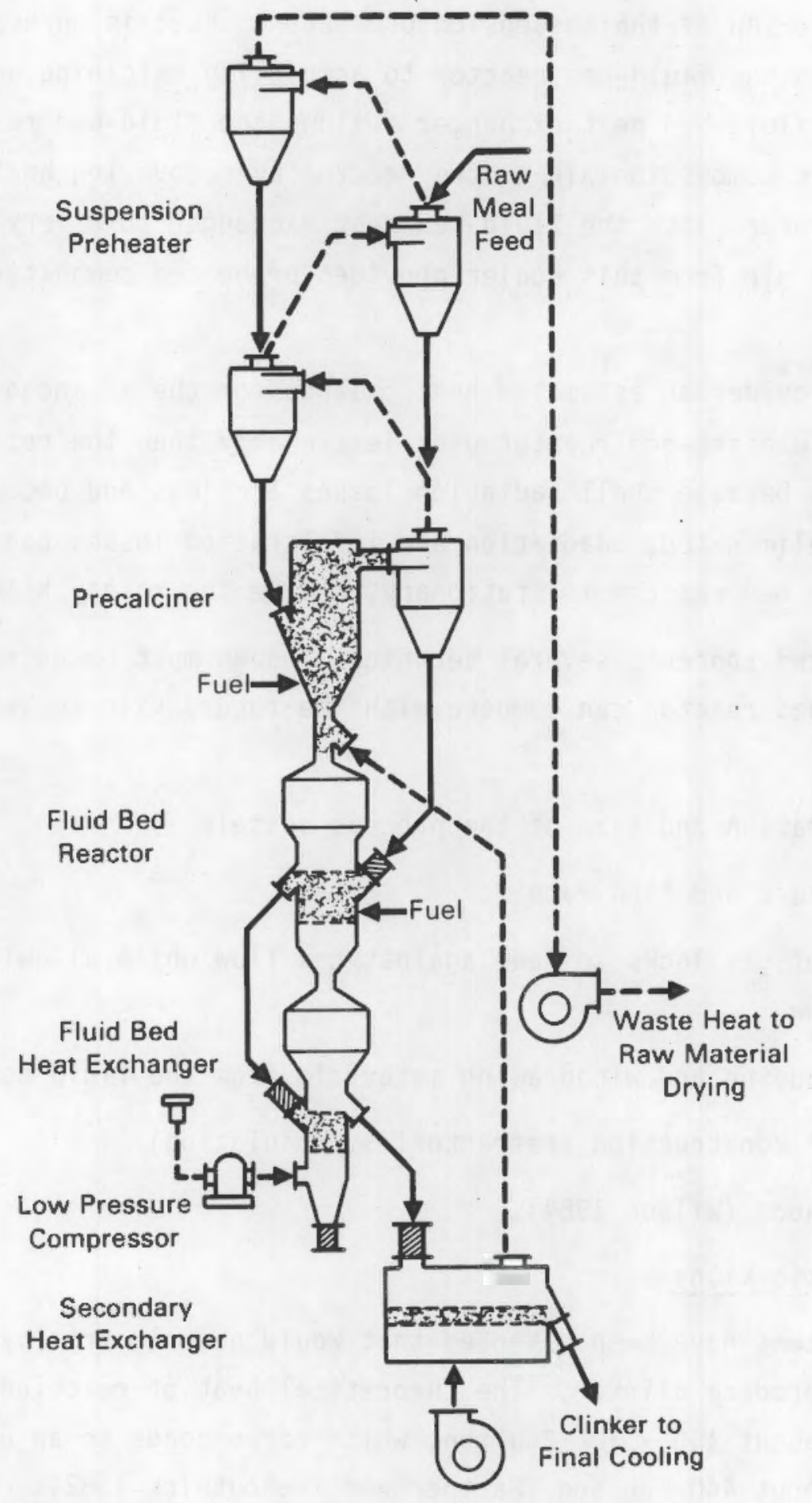

FIGURE 4.4. Conceptual Bendy Engineering Fluid-Bed Kiln (adapted from Wilson 1984) 
meal is fed to the top of the suspension preheater. Fuel is burned in the precalciner and in the fluid-bed reactor to accomplish calcining and sintering, respectively. A fluid-bed heat exchanger follows the fluid-bed reactor and supplies preheated combustion air to the reactor by recovering heat from the clinker. The clinker exits the fluid-bed heat exchanger to a very short gratetype cooler. The air from this cooler provides preheated combustion air to the precalciner.

Table 4.5 provides an estimated heat balance for the advanced fluid-bed concept. This fluidized-bed reactor uses less energy than the rotary kiln process primarily because shell radiation losses are less and because cold air infiltration is eliminated. Radiation and infiltration losses can be reduced because the fluid bed reactor is stationary, unlike the rotary kiln.

As an advanced concept, several technical issues must be addressed before the Bendy fluid-bed reactor can compete with the rotary kiln technology (Wilson 1984):

- the configuration and size of the process vessels

- blower pressure and flow rate

- the design of gas locks to seal against gas flow while allowing material flow

- methods of adding and withdrawing materials from the fluid beds

- materials of construction (refractories, insulation)

- control methods (Wilson 1984).

\subsubsection{All-Electric Kilns}

Several systems have been patented that would use electricity instead of fossil fuels to produce clinker. The theoretical heat of reaction needed to form clinker is about $1.5 \times 10^{6} \mathrm{Btu} / \mathrm{ton}$, which corresponds to an electricity requirement of about $440 \mathrm{KWh} /$ ton (Gartner and Tresouthick 1982). Electrically heated kilns have the advantage of drastically reducing the waste gas heat losses, which currently account for between $20 \%$ and $30 \%$ of the heat input to dry process kilns. 
TABLE 4.5. Advanced Fluid-Bed Heat Balance (adapted from Wilson 1984)

Preheater-Precalciner Section

$10^{6} \mathrm{Btu} / \mathrm{ton} \mathrm{Clinker}$

In: Coal (0.069 tons, $25.2 \times 10^{6}$ Btu/ton) 1.736

Fluid Bed Exit Gas $\left(2355^{\circ} \mathrm{F}\right) \quad 0.528$

Secondary Air \& Humidity $\left(1345^{\circ} \mathrm{F}\right) \quad 0.488$

Exothermic Reaction (60\% of total) 0.216

Preheater Feed $\left(140^{\circ} \mathrm{F}\right) \quad 0.073$

Ambient Air Infiltration $\left(80^{\circ} \mathrm{F}\right) \quad \frac{0.002}{3.042}$

Out: Endothermic Reaction (90\% of total) 1.646

Feed to Fluid Bed $\left(1545^{\circ} \mathrm{F}\right) \quad 0.745$

Exhaust Gas $\left(655^{\circ} \mathrm{F}\right) \quad 0.556$

Dust $\left(655^{\circ} \mathrm{F}\right) \quad 0.023$

Radiation, etc. 0.072

$\frac{0.072}{3.042}$

Fluid-Bed Reactor

In: Coal (0.029 tons, $25.2 \times 10^{6} \mathrm{Btu} /$ ton) 0.744

Feed from $\mathrm{PC}-\mathrm{PH}\left(1545^{\circ} \mathrm{F}\right) \quad 0.745$

Secondary Air \& Humidity $\left(1850^{\circ} \mathrm{F}\right) \quad 0.293$

Exothermic Reaction (40\% of tota 1) 0.144

1.962

Out: Clinker $\left(2380^{\circ} \mathrm{F}\right)$

Fluid-Bed Exit Gas $\left(2355^{\circ} \mathrm{F}\right)$

1.192

0.528

Endothermic Reaction (10\% of total) 0.184

Radiation, etc.

$\frac{0.022}{1.962}$

Fluid-Bed Heat Exchanger

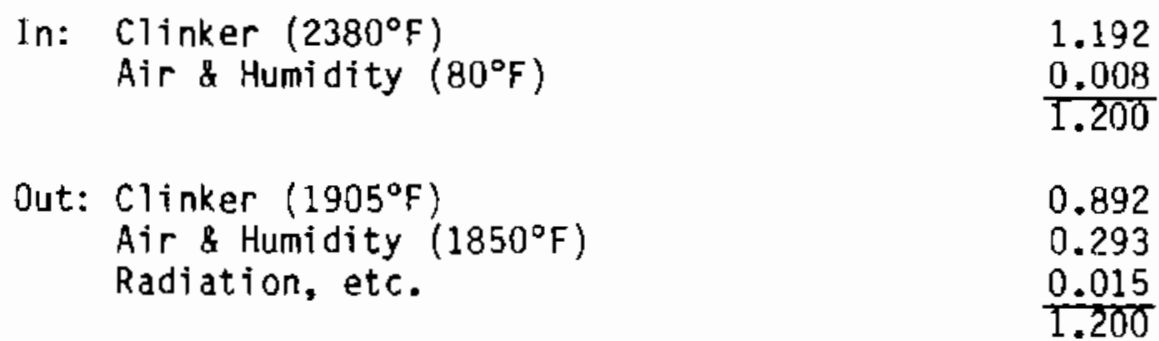




\section{Energy-Savings Potential}

The energy-savings potential of this technolagy is estimated to be about $0.64 \mathrm{Btu} /$ ton equivalent, based on reducing the waste heat losses in the exhaust gases by $80 \%$. This would result in an annual energy savings of $35.6 \times 10^{12}$ Btu at 1982 production levels, or a savings of $12 \%$.

\section{Possible Barriers}

The electric kiln is expected to be prohibitively expensive at current electricity prices. Gartner and Tresouthick (1982) conceptualized a combined electric/fossil fuel system in which the fossil fuels would be used for precalcination and preheating, and the rotary kiln would be electrically heated. This system would still eliminate the large exhaust heat losses from the kiln but would not require the large amounts of power of an all-electric system.

\subsection{ADVANCED KILN CONTROL}

From 1963 to 1972, approximately 20 computers were installed in the cement industry for kiln control. The expectations were for a $3 \%$ to $5 \%$ savings in fuel use, a $10 \%$ to $15 \%$ increase in production rate, a doubling of kiln refractory life, and a more consistent, high-quality product. Initial kiln control efforts were soon abandoned in favor of traditionicl empirical methods because of the difficulty in developing adequate mathematical models of the complex kiln pyroprocess and an inability to develop reliable remote sensors (Garrett 1974).

A second generation of automatic kiln control systems is now available. Among these is the FLS-SOR/fuzzy logic kiln contral system, which relies on indirect measures of process parameters and "fuzzy" logic. The Ash Grove Cement West Company, which implemented the fuzzy controller at its Durkee, Dregon plant in 1981, is the only U.S. cement plant that currently uses the system.

The FLS-SDR/fuzzy-logic kiln control system consists of a minicomputer with graphic CRT (cathode ray tube), operator keytoard, graphic printer, and an interface and process control unit. The system control program is essentially 
a computerized version of the routine control strategies used by an experienced kiln operator. The program takes the general form:

\section{IF [condition], THEN [control action]}

Two main parameters are monitored by the fuzzy controller: 1) the level of nitric oxides (a) in the kiln exhaust, and 2) the liter weight (b) of the clinker leaving the cooler. The program determines whether the burning conditions are optimized based on a statistical correlation between the level of nitric oxide and the liter weight of the clinker. Other parameters, such as the temperature and the level of combustibles and oxygen in the preheater exhaust, are used as consistency checks. If the conditions are not optimal, adjustments are made either to the induced-draft fan speed to control kiln draft or to the coal feed rate. Kiln speed and feed rate are held constant (Sheridan 1983).

\subsubsection{Energy-Savings Potential}

Ash Grove Cement West reports $(c)$ that the primary advantages of the kiln control system are that it 1) helps maintain steady-state operation, 2) avoids overburning, and 3) increases the life of the kiln refractory. The fuzzy logic system makes operating decisions less subjective and more consistent among operators, thus eliminating process upsets that can occur with shift changes.

Although it is difficult to measure the energy savings attributable to fuzzy controller independently of other factors, a $3 \%$ to $4 \%$ increase in fuel efficiency has been reported (Sheridan 1983). The major savings, however, have been in refractory and in the labor hours associated with replacing the kiln refractory. The Durkee plant uses only about half of the refractory per ton of clinker that it used before the fuzzy controller was implemented. Labor hours per ton of clinker have decreased $40 \%$.

(a) Because it is difficult to directly measure burning zone temperature, the amount of nitric oxides in the kiln exhaust gases was selected as the parameter that would be monitored to provide a relative indication of the burning zone temperature.

(b) Liter wejght = grams per liter of clinker screened to a given size range.

(c) Personal communication, September 1984 with Richard Cooke, Plant Manager, Ash Grove Cement West, Durkee, Oregon. 


\subsubsection{Possible Barriers}

The primary constraint to adopting advanced, computerized kiln control systems is lack of reliable remote sensors for directly measuring material and gas temperatures in the burning zone of rotary kilns.

\subsection{CATALYZED, LOW-TEMPERATURE CALCINATION PROCESS}

Catalysts may offer the opportunity to save a significant amount of the pyroprocessing energy by lowering the required calcining temperature. Preliminary work performed by Southwest Research Institute under contract to DOE indicates that alkali metal salts lower the temperature and increase the rate at which limestone can be burned to produce lime. Catalysts made by fusing calcium carbonate with potassium carbonate and sodium carbonate appear to be the most effective. In the tests, the fused salt was pulverized, mixed with powdered limestone, and heated to between $1300^{\circ} \mathrm{F}$ and $1500^{\circ} \mathrm{F}$. Results indicated that the rate of lime formation almost doubled for a 15-minute calcination. The catalyst was separated from the lime using a sieve with little loss of catalyst. Various methods of using the catalyst are being studied, inciuding coating a portion of the kiln wall with the catalyst (0IP 1983a).

\subsubsection{Energy-Saving Potential}

Use of a catalyst allows the calcination reaction to occur at a lower temperature (about $1500^{\circ} \mathrm{F}$ ). It is estimated that the unit thermal energy requirement can be reduced by about $25 \%$ using this process (0IP 1983a). This would correspond to an annual energy savings of $70.4 \times 10^{12} \mathrm{Btu}$.

\subsubsection{Possible Barriers}

Much research remains to be done to ready this technology for commercial application.

\subsection{KILN RADIATION AND INFILTRATIDN LOSSES}

Radiant heat losses and leakage of ambient air into the firing end of the kiln can lower the efficiency of fuel use. Radiant heat losses may account for about $8 \%$ to $15 \%$ of the heat input to the kiln. Even for an efficient precalciner kiln, the shell losses may be as much as $0.2 \times 10^{6}$ Btu/ton of clinker 
(Gartner and Tresouthick 1982). Because of the large surface-area-to-productthroughput of older, smaller rotary kilns, the radiant losses can be quite high. The rotating equipment imposes a weight restriction on the use of insulation.

Inadequate kiln seals allow the air from the clinker cooler, which is used as secondary combustion air, to be displaced by cold, ambient air. More fuel is then required to achieve kiln gas temperature. Again, because the equipment is rotating, the design and maintenance of seals are difficult technical problems.

\subsubsection{Energy-Savings Potential}

Radiation and infiltration losses together account for about $20 \%$ of the heat input to the calcining process. If maintaining insulation and seals could reduce this by one-third, an annual savings of $18.0 \times 10^{12}$ Btu at 1982 production levels could be realized.

\subsection{INTERNAL HEAT-TRANSFER-ENHANCEMENT DEVICES}

Devices that will enhance internal heat transfer include chains, Trefoils ${ }^{*}$ and lifters (Garrett 1984). The intent of these devices is to provide a large contact surface area between the hot combustion gases and the kiln feed material in order to enhance heat transfer efficiency.

\subsubsection{Chains}

Chains can be installed at the feed end of a kiln for two purposes. The chains can absorb heat from the gas stream for transfer to the raw materials as the chains move through the bed material, and they can enhance heat transfer by exposing more of the feed surface to the combustion gases. Chains are used primarily in wet kilns to help with water evaporation, although they also can be used in long-dry kilins.

(3) Trademark of the Harbison-Walker Refractories Group, Dresser Industries, Pittsburgh, PA. 


\subsubsection{Trefoils}

Trefoil systems consist of refractory arches constructed in the transition zone between the preheating and the calcining sections of the kiln. These arches divide the feed into separate streams and thereby enhance heat transfer in two ways. First, the arches provide more refractory surface area to absorb heat from the combustion gases and secondly, they expose more of the feed surface to the hot gases. Improvements in thermal efficiency from these systems have been difficult to measure. Although Trefoils are commonly used in lime kilns, only two cement plants currently use them. Gulf Coast Cement of Houston, Texas, uses Trefoils in its wet kiln, and Lone Star in Cloverdale, Vir. ginia, uses them in its long-dry kilns.

\subsubsection{Lifters or Ledges}

Lifters or kiln tumbling ledges consist of rows of discontinuities installed as part of the refractory lining along the kiln axis. The primary function of the lifters is to increase the material angle of repose to assure that material tumbles rather than slides along the shell refractory lining. The tumbling action increases the thermal efficiency by enhancing the contact between the raw material and the combustion gases. In general, it is believed that in cases where smooth brick or castable refractory allows the material to slide, lifters are a possible thermal-enhancement device. However, if the refractory is rough, spalled or coated, there is a natural surface to induce tumbling action and the lifters will not significantly increase thermal efficiency (Garrett and Murray 1974).

\subsubsection{Energy-Savings Potential}

Table 4.6 shows the fuel savings that are attributed to the installation of chain systems in wet and long-dry kilns. The chain systems must be frequently inspected for wear and replaced to retain maximum heat recovery.

Thermal efficiency improvements resulting from Trefoils or lifters have been difficult to measure. Production increases 1 rom $5 \%$ to $15 \%$ and thermal efficiency improvements from $5 \%$ to $20 \%$ have been reported for Trefoil installations in the lime industry. California Portland Cement reportedly reduced 
TABLE 4.6 Comparison of Fuel Savings for Kilns with and without Chain Systems (Garrett and Murray 1974)

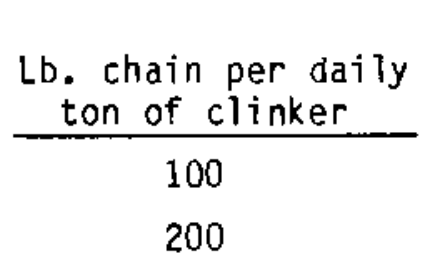

\begin{tabular}{|c|c|}
\hline \multicolumn{2}{|c|}{$\begin{array}{c}\text { Fuel Savings } \\
\text { (Btu per ton of clinker) }\end{array}$} \\
\hline det $\mathrm{kiln}$ & Long-Dry Ki \\
\hline & \\
\hline 2,10 & $1,000,00$ \\
\hline
\end{tabular}

fuel consumption by over $10 \%$ on two dry process kilns through the use of lifters. Results at other plants have been inconclusive (Garrett and Murray 1974).

\subsubsection{Possible Barriers}

The only barrier cited to adopting internal heat-transfer-enhancement devices, other than the cost, is that these additions tend to increase the dust loading in the kiln exhaust. Increased dust loading at the feed end of the kiln results in increased sensible heat losses in the exhaust gases. In addition, the dust imposes an addition load on pollution control equipment.

\subsection{ALKALI SPECIFICATION MODIFICATION}

Raw materials often contain large quantities of alkali metal impurities. In some instances, alkalis can cause a problem in concrete (referred to as the alkali-aggregate reaction), in which compounds in the aggregates react slowly with the alkalis to produce severe cracking in concrete structures. For this reason, low-alkali cements in the U.S. are required to contain less than 0.6 wt\% alkali metals (expressed as $\mathrm{Na}_{2} \mathrm{O}$ ).

Meeting the low-alkali specification requires that many kilns waste a certain percentage of their kiln dust. It is estimated that the cement industry wastes between 10 and 12 million tons of dust annually (0IP 1983b). Preheater kilns, using high-alkali raw materials, must use a bypass system to avoid concentrating alkalis in the clinker. It is estimated that bypassing $10 \%$ of the exhaust represents an additional heat consumption on the order of $0.2 \times$ $10^{6} \mathrm{Btu} /$ : on cement (UTC 1980). The amount of bypass needed with certain raw materials may make a suspension preheater system impractical to operate. For 
example, with a $20 \%$ bypass, about $0.43 \mathrm{million}$ Btu/ton are lost; this represents about half of the potential energy improvement of a suspension preheater over an efficient long-dry kiln (UTC 1980).

Relaxing the alkali specification or applying it only to cases where reactive aggregates are expected could lead to significant improvements in energy efficiency. If it is assumed that about one-third of the energy currently wasted in kiln dusts and in preheater bypass gases could be saved by relaxing the alkali specification, approximately $12.5 \times 10^{12}$ Btu could be saved annually at 1982 production levels. This represents a $4 \%$ energy savings. 


\subsection{FINISH GRINDING}

Finish grinding accounts for most of the electricity used in a cement plant. Thus, technologies that can save energy in finish grinding will have the greatest impact on a plant's electricity use. Technologies that are discussed in this chapter include the following:

- alternative grinding equipment

- improved classification systems

- grinding aids

- fineness specifications.

\subsection{ALTERNATIVE GRINDING EQUIPMENT}

Several alternatives to the conventional ball mill system are being developed for finish grinding. Among these are roller mills, cone crushers and high-pressure roller presses.

\section{1 .1 Roller Mills}

Although roller mills are not used for finish grinding in the United States, encouraging results have been obtained at a plant operated by Teutonia Zementwerke $A G$ in Hannover, Germany, and in a pilot plant at Onoda cement's Tahara plant near Nagoya, Japan.

Roller mills accomplish size reduction as rollers or comparable grinding media travel over a circular bed of material. After the material passes under the rollers, it undergoes preliminary classification with an air stream flowing through the mil1. The air stream carries a portion of the pulverized material to an air classifier, which is normally an integral part of the mill. Oversized particles are recycled to the mill, and the fines are collected in filters and cyclones.

\section{Energy-Savings Potential}

Pilot tests of the Pfeiffer roller mill in Germany and the Kobe-Onoda OK Series roller mill in Japan indicate that between $20 \%$ and $30 \%$ of the electricity used for finish grinding can be saved. The Pfeiffer mill reduced specific 
power consumption from $42.5 \mathrm{kWh} /$ ton to $30.7 \mathrm{kWh} / \mathrm{ton}$. (a) Power consumption for grinding one metric ton of clinker ranged from $25 \mathrm{kWh}$ to $29 \mathrm{kWh}(60 \%$ to $70 \%$ of conventional tube mill use) with the OK Series roller mill (Shimojima et al. 1984).

Roller mills may have the additional advantage of eliminating the need for cement coolers because it is easier to keep the cement temperature low during grinding in a roller mill. Eliminating the coolers would result in additional energy savings and in capital savings in new plants.

\section{Possible Barriers}

The major barriers to adopting roller mills for finishing grinding are expected to be 1) the industry's lack of investment capital, and 2) difficulty in marketing the cement produced with roller mills under current cement particle size specifications. With roller mills, the particle size distribution differs from that obtained from ball mills. West German specifications call for an upper limit on the 28-day strength and do not control the particle size. With this type of performance specification, roller mills can be more easily adopted for finish grinding.

\subsubsection{High-Pressure Roller Press}

High-pressure roller presses are being developed by Humboldt Wedag and by Polysius to save energy in grinding cement clinker. The Humboldt Hedag high pressure roller press was developed by modifying the design of one of their briquetting presses. This press consists of twin rollers, each equipped with its own drive. A hydraulic-pnuematic system keeps the gap between the rollers constant or maintains a constant pressure while allowing one of the rollers to float. The press is installed ahead of the conventional, closed-circuit grinding mill in the cement plant. The crystalline structure of the clinker is fractured in the press, and fine grinding and sizing is performed by the conventional mill.

(a) Personal communication with Thomas Brown, Allis-Chalmers Corp., Milwaukee, Wisconsin. 
The high-pressure roller presses can be installed in new plants or retrofitted to existing equipment. Although no units have yet been installed in the U.S., Humboldt Wedag has recently sold two of its presses to cement companies in Germany and Peru.

\section{Energy-Savings Potential}

Tests of the Humboldt Wedag High Pressure Roller Press, conducted in a commercial cement plant in 1982, produced cements with a fineness between 2900 and 4300 Blaine. An overall reduction in grinding energy of between $20 \%$ and $30 \%$ was achieved. The savings in electricity were found to be greater with lower Blaine products and with harder materials. For example, the benefits of the system are greater with slag as compared with clinker.

Possible Barriers

No barriers, other than the cement industry's lack of capital, have been identified.

\subsubsection{Cone Crushers}

In Germany, cone crushers are used in series to produce fine particles. This technology may be applicable to finish grinding. Cone crushers are reportedly more efficient than conventional grinding mills, although little information is available at this time. (a)

\subsection{IMPROVED CLASSIFICATION}

Closed-circuit cement grinding systems must separate the fine, productquality particles from the coarser, oversize particles that are recycled for further grinding. To be effective, the separator (or classifier) must have good selectivity (defined as the percentage of a given particle size that is discharged in the recycle or tailings) to prevent recycling fines back to the mi11. Conventional air classifiers typically recycle as much as $60 \%$ of the product-quality fines back to the grinding mill. The result is overgrinding, which de:eriorates product quality and increases energy use.

(a) DOE is currently evaluating the potential of cone crushers for finish grinding. 
A new generation of vortex air classifiers has recently been introduced. These classifiers achieve high separation efficiericies with less power consumption and lower capital costs than the earlier generation of classifiers. These classifiers use a horizontal air stream in the separation zone. (The dominant air direction in a classical separator is vertical). These "side-draft" classifiers provide for longer particle residence times in the separation zone, thereby mitigating the entrapment of fine particles by coarse ones. In addition, the problem of fines bypassing is prevented without incurring high capital and power costs associated with the external fans used for this purpose in the earlier systems (Klumpar, Currier and Ring 1984).

Several companies are marketing or developing high-efficiency, side-draft classifiers, including the following:

- Onoda Cement Company, Japan - 0-SEPA

- Sturtevant, Inc., Boston, Massachusetts - SD-High-Efficiency Classifier

- Polysius, Germany - CYCLOPOL

- C-E Raymond - High-Efficiency Mechanical Air Separator

- Baver, Springfield, Ohio - Centri-Sonic Classifier.

An example of a side-draft classifier (0-SEPA) is shown in Figure 5.1 .

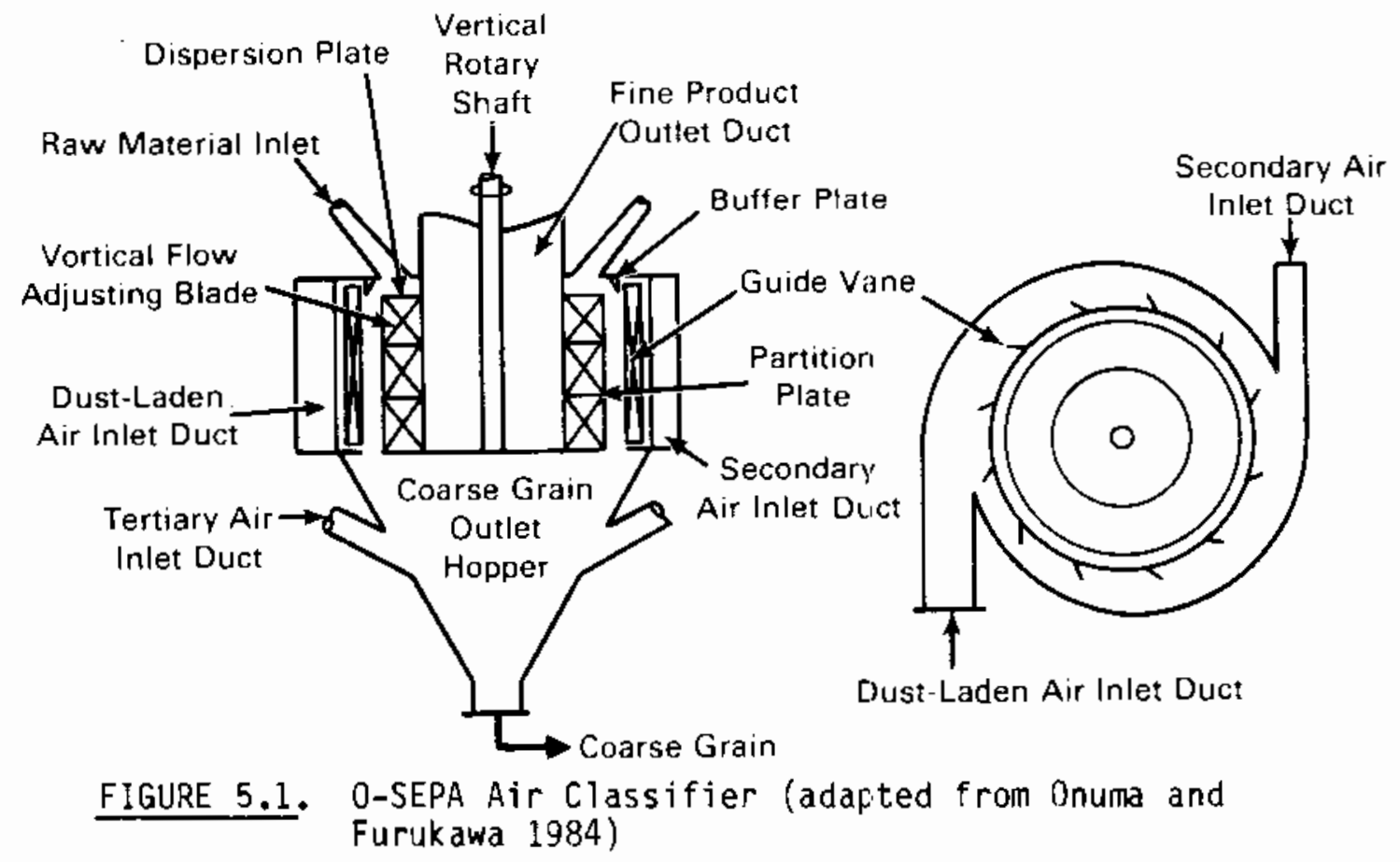


In the 0-SEPA, the particles to be classified are highly dispersed by the dispersion and buffer plates located near the feed inlet. The dispersed particles are thrown into the classifying air via tangentially extended ducts. The classifying air, most of which can be made up of the dust-laden air from the mill, enters the classification zone through fixed guide vanes. The flow adjusting blades and the horizontal partition plates act to form a precise horizontal vortex. The combined centrifugal force and inwardly flowing air separates the finer particles, which are ducted out of the classifier. The coarser jarticles swirl down the inside of the guide vanes. In the guide vanes those particles are first blown by the air entering the lower part of the ducts and then reclassified by the tertiary air supply. Finally, the coarse particles flow out the bottom of the classifier and are returned to the mill.

0-SEPA air classifiers have been in operation in Japan since 1979. Florida Mining and Materials is currently installing an 0-SEPA system at its Brooksville, Florida, grinding facility. In addition to its application in cement grinding, the 0 -SEPA has been used with slag-grinding ball mills.

\subsubsection{Energy-Savings Potential}

Because of the improved classification characteristics of side-draft classifiers, much fewer fine particles are returned to the mill from the classifier than with conventional air classifiers. This enhances the grinding efficiency of the mill (capacity is increased and energy requirements are reduced). Because the new classifiers are more compact than conventional classifiers, the capital costs may be lower.

Onoda reports that the specific energy consumption ( $k$ Wh/ton) for the grinding of ordinary portland cement is decreased. $8 \%$ to $20 \%$ with the 0-SEPA air classifier (0numa 1983, 1984). The other new, side-draft classifiers are reported to be comparable to the 0-SEPA.

\subsubsection{Possible Barriers}

No barriers other than the industry's lack of capital to invest in any new equipment have been identified with this technology. 


\subsection{GRINDING AIDS}

Grinding aids are organic compounds which act as surface active agents for the clinker or the grinding media. These additives prevent the formation of agglomerates by helping to disperse the pulverized material. The objective of grinding aids is either to increase mill throughput without increasing the fineness of the product, or to increase the fineness of the product at a constant throughput. Many chemical compounds have been used to attempt to achieve increases in grinding efficiency. Although in many cases laboratory tests have demonstrated increases in grinding rates with various chemicals, subsequent tests in industrial facilities have failed to reproduce the results obtained in the laboratory (Hartley, Priestly and Wick 1978). Additives that have been tested with cement clinker are summarized in Table 5.1, along with the reported improvement in the grinding rate. For economic reasons, inexpensive industrial by-products are used as grinding aids in commercial applications. The predominant additives used by the cement industry are ethanol amine and polyvalent alcohols (Drombrowse, Hoffman, and Sheibe 1982).

TABLE 5.1 Additives Used in Cement Industry Grinding Operations (adapted from Hartley, Priestly and Wick 1978)

\begin{tabular}{|c|c|c|}
\hline Additive & \% Added & $\begin{array}{l}\text { Grinding } \\
\text { Rate (a) } \\
\text { Factor (a) }\end{array}$ \\
\hline Water & 0.04 & 1.3 \\
\hline $\begin{array}{l}\text { Phenol and } \\
\text { Polyphenol }\end{array}$ & 0.01 & -- \\
\hline Acetone & 0.2 & 1.37 \\
\hline Sulfonic Acids & 0.06 & 1.3 \\
\hline Sodium Stearate & 0.15 & 1.2 \\
\hline Napthenic Acid & 0.1 & 1.33 \\
\hline Carbon Black & 0.08 & 1.3 \\
\hline
\end{tabular}

(a) Grinding Rate Factor = new surface produced with additive/new surface produced without additive. 
The Ideal cement plant in Seattle, Washington, uses lignicite (a by-product of the pulp and paper industry) as a grinding aid. It is reported that sulfite-alcohol residues and triethanolamine are widely used in the Soviet Union to intensify grinding of clinker, to raise productivity, and to save energy (Boldyrev 1983).

\subsection{GRINDING MEDIA AND MILL LINING}

Grinding operations are complex in terms of the number of factors that affect power consumption. Currently, actual grinding mechanisms are not sufficiently understood to base mill design and operation on anything other than long-established empirical relationships derived from successful past experience. Grinding media and mill lining material are usually selected according to the wear characteristics of the material because those characteristics affect replacement costs. However, increases in the specific gravity and surface hardness of grinding media and wear-resistant mill linings have reportedly shown significant potential for reducing energy use in grinding (McIvor 1983).

The effect of lining wear on power consumption is particularly dramatic in smaller diameter mills. For example, 2 inches of liner wear result in about a $14 \%$ increase in power consumption in an 8-ft diameter mill and about a $6 \%$ increase in a 16.5-ft diameter mill (McIvor 1983). The potential energy savings from alternative grinding media and mill liner materials cannot be determined because sufficient information is not available.

\subsection{SENSDRS ANO CONTROLS}

Computer control of grinding circuits using analog systems and data loggers is well established. The next generation of control systems for optimizing the performance of finish grinding mills is expected to be an extension of direct digital computer control.

Grinding circuits are continualiy faced with changes in feed characteristics that cause the operating conditions to deviate from optimal design conditions. The frequency of these deviations and the response time and reliability of manual operation make computerized control systems particularly attractive for optimizing grinding operations. 


\subsubsection{Energy-Savings Potential}

The Portland Cement Association reports energy-efficiency improvements of up to $15 \%$ with automatic control systems (PCA 1975).

\subsubsection{Possible Barriers}

Capital constraints and lack of operating experience are the major barriers to adopting computerized control.

\subsection{MODIFYING FINENESS SPECIFICATIONS}

The surface area and the particle size distribution control the strength development of a cement made from a particular clinker. The surface area controls the early strengths of cements (1-day and 3-day strength), whereas the particle size distribution affects later strengths (28-day strength). The U.S. market has traditionally preferred high early strengths (high-surface-area cements). The high-surface-area cements produced in the United States require $15 \%$ to $25 \%$ more power for finish grinding than is used in other countries (PCA 1975).

In Japan ordinary (Type I) cements are ground to an average of about 3000 Blaine, (a) whereas in the $1 \mathrm{~J} . \mathrm{S}$. the average is between 3600 to 3800 Blaine. About $20 \%$ more power is required in the U.S.(b) In the Federal Republic of Germany, rather than using a prescriptive specification on fineness, a performance standard based on a 28-day strength is used (PCA 1975).

\subsubsection{Energy-Savings Potential}

According to the Portland Cement Assocjation, relaxing the fineness specification for ordinary cements to about 3000 Blaine, as in Japan, has the potential of saving $15 \%$ to $25 \%$ in grinding energy (PCA 1975).

\subsubsection{Possible Barriers}

Market acceptance of cements with lower early strength and reluctance to change ASTM and National Bureau of Standard's specifications and standards are the major barriers.

(a) Surface area measured in $\mathrm{cm}^{2} / \mathrm{g}$.

(b) Personnel communication with Russ McMann, Gifford-Hill and Company, Midlothian, Texas. 


\subsection{WASTE MATERIALS UTILIZATION}

In this chapter, the use of waste materials as raw materials or as fuel in cement-making operations is discussed.

\subsection{WASTE MATERIALS AS FUELS}

The high kiln temperature, long residence time in the burning zone and the scrubbing action of the material in the kiln allow the cement manufacturing process to use a wide range of fuels. Although alternative fuels do not offer energy savings in terms of reducing the energy required to produce a ton of clinker, they do offer two opportunities: 1) to make productive use of materials that might otherwise be wasted, and 2) to provide lower-grade heat without using high-grade fuels. Alternative fuels also can offer significant cost savings to the cement plant. Alternative fuels that have been used in various cement kilns, both domestic and foreign, include petroleum coke, municipal wastes, rice hulls, wood chips, rubber tires, battery cases, hazardous wastes, and waste oils derived from the production of organic polymers.

Petroleum coke is the predominant waste fuel used by the cement industry, accounting for about $3 \%$ of the total fuel used. The amount of coke used is typically reported along with the amount of coal used rather than listing it as a waste fuel in reports of cement industry energy usage (See Johnson and Absalom 1982; Roy 1983). Waste materials other than coke have not yet been widely applied in the U.S. cement industry. Most of the pioneering work in the use of waste fuels has taken place in foreign countries, particularly in the United Kingdom, Norway and Japan. The experiences of individual plants in using particular waste materials as fuels are briefly described in the following subsections.

\subsubsection{Municipal Wastes}

BTule Circle Cement of the United Kingdom has developed a rotary cement kiln tha: augments its coal fuel with refuse-derived fuel collected from local municipal areas. The plant is similar to existing rotary kilns, with the modifications confined to the firing sections of the kiln. The system is not 
designed to replace other fuels, but rather to use the fuel value of the refuse as a supplement to the primary fuel (coal or fuel oil). A substitution rate of about $20 \%$ has been achieved since the plant began operation in 1979 (Fuel \& Energy Consultants, Inc. 1982).

Before the combustion of the refuse can occur, incombustible materials such as metals are removed by magnetic separation. The Blue circle cement system shreds the waste and uses air blowers to separate out glass and metal. Increasing the shredding to produce smaller refuse particles was found to enhance the separation of combustible and noncombustible materials. Testing has shown that no increase in dust and particles in kiln exhausts has resulted from using refuse-derived fuel, nor has product quality decreased (Fuel and Energy Consultants, Inc. 1982).

Refuse-derived fuel has been used in both wet and dry process cement kilns. Blue Circle has achieved a savings of $20 \%$ in its operation (Fuel and Energy Consultants, Inc. 1982).

\subsubsection{Rice Hulls and Wood Wastes}

Genstar's plant in Redding, California, began experimenting with waste fuels in 1975. At that time the plant burned natural gas in a long-dry kiln. The wastes that were burned in conjunction with the natural gas included rice hulls and dry planer shavings. The rice hulls have an ash content of about $17 \%$, while that of the wood shavings is about $0.5 \%$. These materials were blown into the burning zone of the long-dry kiln through a 6-inch line. Genstar experienced no problems with these materials when using natural gas. However, in 1977, when the plant converted to coal, it began to experience problems with ash rings, which were thought to be caused by the high ash content of the hulls. For this reason, the burning of hulls was minimized in preference of the wood wastes. Genstar was able to provide up to $50 \%$ of its heat requirements with the waste materials in its long-dry kiln (Segal 1984).

In 1980, Genstar replaced its long-dry kiln with an F.L. Smidth preheater/precalciner kiln. Waste materials are now blown into the precalciner instead of the $\mathrm{ki}$ in and meet about $15 \%$ of the thermal requirements of the process. Genstar has experienced some problems with buildups in the precalciner. 
The current system does not employ an alkali bypass, and all dust is recycled to the blending silos (Segal 1984).

Table 6.1 provides relative cost data for the conventional fuels and the waste-derived fuels used by Genstar.

\subsubsection{Rubber Tires}

The Japanese were the first to make use of rubber tires for kiln fuel. Rubber tires are also burned at a number of European cement plants. Firms in Japan and Germany generally burn tires whole. In Japan, Chichibu Cement's Kumagaya plant burns 40 tons of tires per day in a preheater (4500 mt/day) and a precalisiner kiln (7800 mt/day). The tires cost between $\$ 16$ and $\$ 21$ per ton (Huhta 1,384).

Rubber tires have been used to a limited extent in the United States. Shredded tires have been preferred because of the expense of whole tire handling systems, which may run from about $\$ 600,000$ to $\$ 1,000,000$. (a) Currently, about 170 million scrap tires are discarded in the U.S. each year, each with a heating value of about $300,000 \mathrm{Btu}$ (Dodds 1984). This resource could potentially supply about $18 \%$ of the cement industry's fuel.

The Genstar Redding plant ran a one-day test with chipped rubber tires. During the test, the tires accounted for about $10 \%$ of the thermal input to the kiln (Segal 1984). The relative cost of rubber tires compared to the fuels used at the Redding plant is shown in Table 6.1. Ash Grove's Durkee, Oregon, plant experienced some preheater buildup problems when they burned shredded rubber tires. As with the Redding plant, the Ourkee plant operates with no alkali bypass because of its low-alkali raw materials, and it recycles all of its dust.

\subsubsection{Hazardous Wastes}

The Norcem cement plant in Slemmestad, Norway, began testing the use of hazardous wastes as kiln fuels in 1981. Materials that have been tested include waste oils, aromatic solutions, chlorinated solutions, PCB oil, tars

(a) Personal communication with Julie Dodds, EG\&G, Idaho Falls, Idaho. 
TABLE 6.1. Relative Costs of Fuels Used at Genstar's Redding, California Plant (Segal 1984)

\begin{tabular}{|c|c|c|}
\hline Fuel & Relative Cost & $\begin{array}{l}\text { Energy Content } \\
(\mathrm{Btu} / \mathrm{lb})\end{array}$ \\
\hline Coal 1 & 1.0 & 13,000 \\
\hline Gas & 2.5 & $1.020 / \mathrm{cu} \mathrm{ft}$ \\
\hline Rice Hulls & 0.9 & 6,200 \\
\hline Wood Chips & 0.7 & 7,400 \\
\hline Coke & 0.6 & 15,000 \\
\hline Rubber Tires & 0.6 & 14,000 \\
\hline
\end{tabular}

and heavy organics from the petroleum industry, and chlorinated organics from vinyl chloride monomer production. The test kiln was a wet process $k i l n, 500$ feet long $\times 13$ feet diameter. Normal fuel consumption was 150 tons of coal for a production of 850 tons of clinker per day. A waste burner, which tolerates solids up $5 \mathrm{~mm}$ in diameter, was installed in combination with the coal burner. The tests indicated that incineration of these wastes in a cement kiln provided a high degree of destruction (99.99999\%) and did not affect the quality of the cement produced. In some cases a slight increase in the dust emission from the kiln was observed (Trovaag 1983).

The system for incinerating 20,000 cubic meters of hazardous wastes per year at the Norcem plant is estimated to cost $\$ 30$ million and is reportedly competitive with a modern dry kiln using conventional fuels (Trovaag 1983). Annual operating costs and savings are given in Table 6.2.

\section{1 .5 Waste 0il}

Giant Portland and Masonry Company of Harleyville, South Carolina, has four wet-process kilns. Each is equipped with a burner system that can fire coal, oil, natural gas or a combination of these fuels. For kiln startup and as an alternate to their primary fuel (coal), Giant Portland uses a wastederived fuel comprised of $30 \%$ to $50 \%$ waste from a hydrocarbon polymerization process, $20 \%$ No. 2 fuel oil, and the remainder a lighter waste-derived hydrocarbon. 
TABLE 6.2 Cost/Benefit of Hazardous Waste Incineration

(Trovaag 1983)

\begin{tabular}{c}
$\begin{array}{c}\text { Excome } \\
\text { (millionses } \$)\end{array} \quad$ (million \$) \\
\hline
\end{tabular}

Cost Savings:

12,000 tons coal

$\$ 60 /$ ton

0.72

Fees Charged

0.60

Operating Costs

Net annual contribution

0.50

0.82

Giant found that their waste-derived fuel had to be hotter than No. 6 fuel oil for good atomization and that it has a tendency to stiffen to a high viscosity in small pipes, making heat tracing and oil circulation critical factors. As with No. 6 fuel oil, overheating causes the formation of solid coke, which clogs the burner orifices. When clogging occurs, the burners must be mechanically cleaned (Reber 1984).

\subsubsection{Energy-Savings Potential}

Although the use of waste materials as fuels does not reduce the total amount of heat consumed in the process, it does reduce the amount of conventional fuels used. The conventional energy-savings potential of burning waste materials is a function of the amount that is substituted for the conventional fuel. The high temperature required in the burning zone of rotary kilns ordinarily requires that at least part of the fuel be high-grade. However, the precalciner concept offers the opportunity to use a higher percentage of lowergrade fuels.

\subsubsection{Possible Barriers}

The primary technical barrier to using waste materials as fuels is the lack of information and experience in identifying potential problems and solutions. There are concerns both with the quality and the availability of waste materials. Because of the higher ash content in wastes compared with conventional fuels, there is concern that kiln, preheater or waste heat boiler 
buildup problems could increase. Besides these technical barriers, public acceptance of the use of waste fuels in neighboring cement plants could be a barrier.

\subsection{BLENDED CEMENTS}

Blended cements can be made at the cement plant by combining portland cement with various additives either through intergrinding or through mixing after separate grinding of the portland cement clinker and the additives. The ready-mix concrete manufacturer may substitute additives with cementitious or pozzolanic(a) properties for portland cement in concrete. Although such substitution will not reduce the energy consumption an a Btu/ton of clinker basis, this practice will save energy on a Btu/ton of corcrete basis.

Blended cements (particularly with granulated slag) have been manufactured in Europe, uapan and the Soviet Inion for several years. Various pozzolans have been proposed and investigated for making blended cements. These additives include industrial wastes or by-products (stich as fly ash from coal-fired power plants and glassy, granulated iron blast furnace slag), cement kiln dust, and naturally occurring pozzolans. Each of these is discussed below.

\section{2 .1 Fly Ash}

Fly ash is obtained in the dust collection equipment of furnaces fired with pulverized coal, particularly those of electricity-generating plants. Fiy ash consists mainly of $\mathrm{SiO}_{2}, \mathrm{Al}_{2} \mathrm{O}_{3}$ and $\mathrm{Fe}_{2} \mathrm{O}_{3}$. It is finely divided and usually requires little or no processing before being used in blended cements.

\section{2 .2 Blast Furnace Slag}

Blast furnace slags require special processing such as granulation to develop their full potential reactivity. Slags tend to be more difficult to grind than portland cement clinker, making final grinding of slag cements more

(a) Pozzolans are siliceous or siliceous and aluminous materials which in themselves possess little or no cementitious properties, but which will, if finely divided, react chemically with calcium hydroxide and moisture at ordinary temperatures to form compounds with cementitious properties. 
energy-intensive than grinding clinker (Brown et al. 1976). However, the additional grinding power required is offset by the reduction in kiln energy use. Rather than grinding blast furnace slags with clinker, the Japanese report that pregrinding the two separately prior to mixing or finai grinding leads to a more uniform, high-strength product (PCA 1975).

Atlantic Cement's slag facility at Sparrow's Point, Maryland, which was brought on-line in 1982, was the first of its kind in the U.S. Atlantic Cement uses a water system to granulate slag from a Bethiehem Steel blast furnace. The slag and the clinker are ground separately and are subsequently mixed to customers' specifications at concrete batch plants. Atlantic Cement reports that separate grinding is far more efficient and that it prevents overgrinding of the clinker and the calcium sulfate (gypsum) (Burriss 1981). Currently, less than $1 \%$ of the cements produced in the United States are blended cements. Blended cements can potentially be substituted for all cements with the exception of high early-strength cement, which accounts for less than 3\% of the annual portland cement consumed.

In Germany, it is common for steel companies to purchase clinker and use their slag to produce cement. About $50 \%$ of all cement in Germany contains an average of $60 \%$ iron blast furnace slag.

\subsubsection{Cement Kiln Dust}

In cement plants, the usual practice is to return as much cement kiln dust as possible to the kiln. However, due to its high alkali content, large quantities of kiln dust cannot be recycled to the kiln. The cement industry currently produces about 10 to $12 \mathrm{million}$ tons of waste cement-kiln dust annually (OIP 1983b). This amounts to about 0.14 tons of cement kiln dust per ton of portland cement produced. Cement kiln dust is similar in composition to that of the cement kiln raw feed, but the amount of alkalis, chloride and sulfate is usually considerably higher. In addition, the dust may contain varying amounts of free lime, clinker, and raw feed minerals. Because the dusts contain higher alkali concentrations, it has been proposed that kiln dust-fly ash blends be used to control alkali-aggregate expansion. Preliminary work in this area has 
been performed by the Portland Cement Association, by DOE and by the Department of Transportation and by the Summa 1 Corporation (Bhatty 1984; DIP 1983b).

\subsubsection{Natural Pozzolans}

Natural pozzolans, such as pumice, pumicite and volcanic cinder, tufas, and expanded shales, occur in isolated areas of the western United States and are primarily associated with volcanic activity. Although drying is usually unnecessary, in most cases these materials would require size reduction prior to use in blended cements (PCA 1975). Some pozollans (zeorites, clays, and shales) would require calcination prior to their effective use, making them less attractive than other materials.

\subsubsection{Energy-Savings Potential}

The energy-savings potential of blended cements depends on the proportion of waste material that is interground with or substituted for portland cement in concrete. Currently, approximately one ton of portland cement is used to make four cubic yards of concrete (Dikeou 1980). Some experts believe that on the average U.S. concretes could use half as much cement and still yield the desired properties. This would reduce the total energy embodied in the final concrete product.

The manufacture of blended cements reportedly requires less energy on a per-ton basis than the manufacture of portland cenent, roughly in proportion to the amount of waste material that is added (Brown et al. 1976). That is, adding $20 \%$ of a waste material to cement yields an energy savings of approximately 20\%. Although additional grinding energy is required with the use of blast furnace slag, the savings in kiln energy use more than offsets it.

Table 6.3 shows the potential annual energy savings at 1982 production levels for various percentages of waste material added either by intergrinding or substitution at the concrete plant. 
TABLE 6.3. Approximate Energy-Savings Potential of Blended Cements or Cement Substitutes

\begin{tabular}{ccc}
$\begin{array}{c}\text { Percent of } \\
\text { Waste Material } \\
\text { Added }\end{array}$ & $\begin{array}{c}\text { Million } \\
\text { Btu/Ton } \\
\text { Saved }\end{array}$ & $\begin{array}{c}\text { Million } \\
\text { Btu/Year } \\
\text { Saved }\end{array}$ \\
\cline { 3 - 4 } 10 & 0.5 & 30 \\
20 & 1.1 & 60 \\
50 & 2.7 & 150
\end{tabular}

Consumers of concrete products are concerned with the durability of blended cements, particularly with regard to freezing, thawing and resistance to sulfates. The cold weather performance of these materials is not yet completely understood.

Another barrier is that current ASTM cement standards are based on composition rather than on performance. These standards limit the amount of waste material that can be used, although tests have shown that greater amounts can be used without affecting the strength of the product (except in the case of high early-strength cements).

An additional impediment to the use of substitutes for portland cement in concrete is that clinker producers would face reduced capacity demand if this were to occur. The cement industry is currently operating below capacity (in 1982 only $58 \%$ of the clinkering capacity was used). Diluting the final product by using substitutes for portland cenent in concrete would further reduce the demand for clinker and thus the capacity utilization. Such a reduction is not in the economic interest of clinker producers. Although the cement plant would reduce its energy costs on a net basis, the savings would occur at the expense of reduced clinkering capacity.

\subsubsection{Possible Barriers}

The major technical barrier to using waste materials in cement is the quality control of the material homogeneity. The carbon content must be closely monitored and the amount of waste added must be adjusted when the carbon varies. 


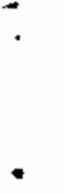




\subsection{COGENERATION}

In this chapter, two cogeneration technologies that are applicable to the cement industry are described. Cogeneration is the sequential production of useful heat and power from the same energy source. The large amounts of waste heat rejected from cement-making operations provide substantial opportunity for bottoming-cycle systems, which recover waste heat to generate electricity. The two types of cogeneration systems that are discussed in this chapter are steam Rankine systems and organic Rankine systems. Steam Rankine systems have traditionally been used with kiln exhausts greater than about $1000^{\circ} \mathrm{F}$. Organic Pankine systems are being developed for low-temperature heat recovery. Following brie descriptions of each system, the energy-savings potential and potential barniers of each are discussed.

\subsection{STEAM RANKINE CYCLE}

Currently, four plants recover heat from long-dry kiln exhausts to operate steam Rankine bottoming cycles for power production (see Table 2.4). A fifth plant is scheduled to complete a waste heat boiler facility in 1985.

The steam Rankine system is typically installed between the kiln and the baghouse dust-removal system in the space generally occupied by the kiln exit gas cooler (Breindel, Collamore and Goetz 1979). The exhaust gas is ducted through the waste heat boiler, and heat is transferred to the water to produce superheated steam. The steam is expanded through a turbine to generate shaft power to drive a generator. The turbine exhaust is then condensed and recycled to the waste heat boiler.

Nihon cement company has operated a steam Rankine system for lowertemperature heat recovery at its Kawara plant since 1981. The dual-pressure system recovers $770^{\circ} \mathrm{F}$ heat from the preheater and $446^{\circ} \mathrm{F}$ heat from the airquenching cooler. The rated output of the system is 16,200 $\mathrm{kW}$ and the payback period was about three years (Power 1985). 


\subsection{ORGANIC RANKINE CYCLE (ORC)}

Organic Rankine bottoming cycles may provide a practical way to recover the low-temperature heat associated with the preheater or precalciner kilns. Although no ORC systems are currently operating in U.S. cement plants, they have been used successfully in other industries in foreign countries.

The ORC is similar to the steam Rankine system discussed above, with the exception that a low-boiling-point organic fluid replaces water as the heat transfer medium (see Figure 7.1). ORC systems are potentially up to $50 \%$ more efficient than steam Rankine systems at temperatures below $1000^{\circ} \mathrm{F}$ (Breindel, Collamore and Goetz 1979).

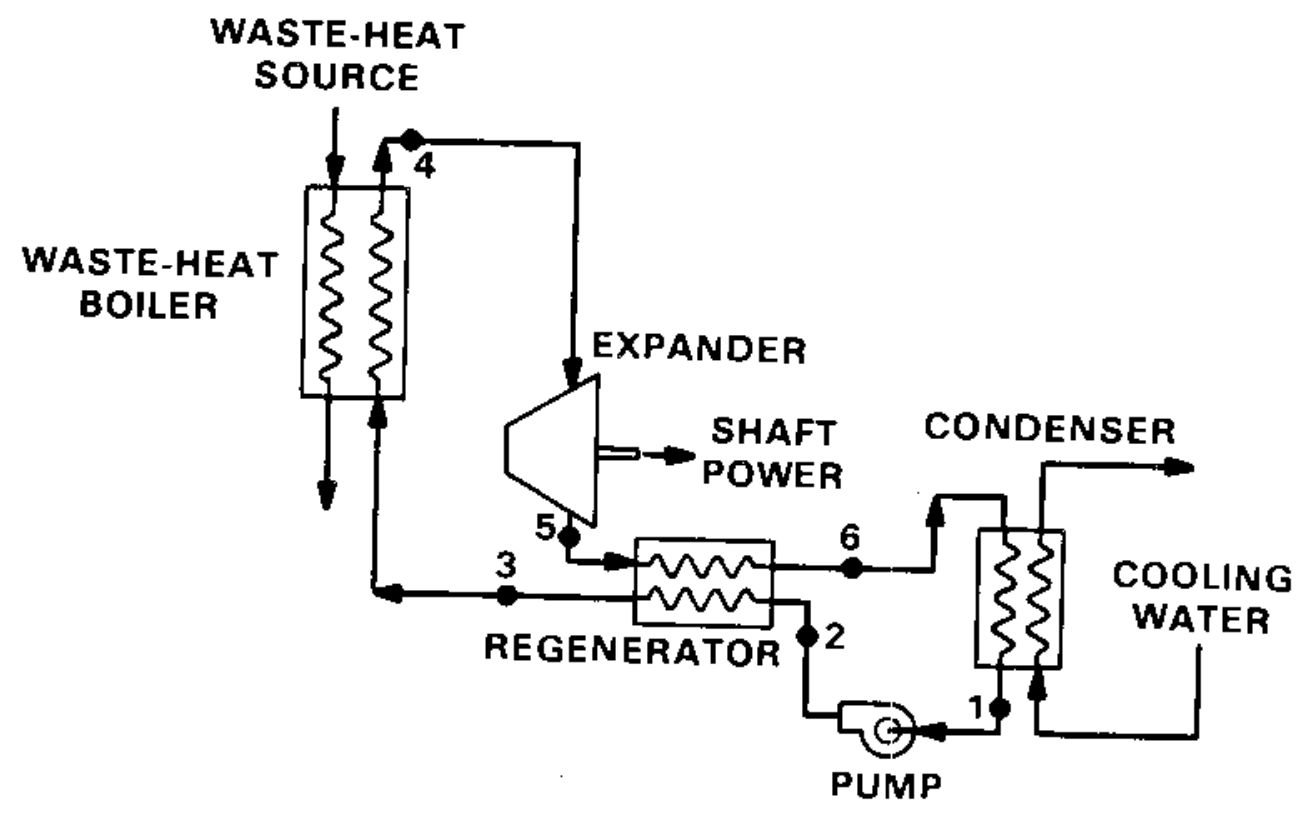

FIGURE 7.1. Organic Rankine Bottoming Cycle

Domestic firms have developed ORC systems for a variety of applications, including solar and geothermal applications, bottoming cycles for engines, and industrial waste heat recovery. A large share of the development and demonstration efforts in the U.S. has been funded by DOE as a part of solar, geothermal or conservation programs. Most of the U.S. systems are at the prototype stage, with few commercial installations currently operating or under construction (Garrett-Price, Barnhart and Eschbach 1982). 
Several foreign firms have been active in ORC development and manufacture. Japanese government and industry, driven by their dependence on energy imports, have been involved in ORC research and testing for more than 15 years. Sofretes, a French firm, is now producing a limited number of ORC units for water pumping. Ormat, an Israeli firm, has been manufacturing smaller ORC units $(1 \mathrm{~kW})$ for more than 15 years. The latter two firms primarily market their ORC systems to developing countries for remote applications (GarrettPrice, Barnhart and Eschbach 1982).

\subsection{ENEZGY-SAVINGS POTENTIAL}

Estimates of the energy-savings potential of the steam Rankine and the organic Rankine bottoming cycles are provided in this section. Steam Rankine systems are applicable at exhaust gas temperatures commonly associated with long-dry kilns and preheater bypasses. Preheater exhausts, which are lower in temperature than long-dry kiln exhausts, could more efficiently be recovered with an organic Rankine cycle system. Exhaust gases from efficient, well-maintained wet process kilns are too low in temperature and too high in moisture for practical heat recovery with currently available heat-recovery steam generators. The following energy-savings estimates were made assuming that a steam Rankine bottoming system would be used in conjunction with existing long-dry kilns and that an ORC system would be used with preheater or precalciner kilns.

\subsubsection{Steam Rankine Cycle}

If an average of $34 \%$ of the energy introduced to the kiln is exhausted in the waste gases, then about $1.60 \mathrm{million} B$ tu/ton clinker was exhausted from long-dry kilns in 1982. This amounted to a total of $19.4 \times 10^{12}$ Btu of heat at 1982 production levels. If an average electric generation efficiency of $20 \%$ is assumed for the steam-Rankine heat-recovery system, about 1.1 billion $\mathrm{kWh}$ of electricity could be generated from all long-dry kilns. This represents an increment of about 0.8 billion $\mathrm{kWh}$ above what was actually generated in 1982 . This is equivalent to an annual electricity savings of $10 \%$ at 1982 production levels. The trend toward adopting preheaters and precalciners will reduce this potential savings. 


\subsubsection{Organic Rankine Cycle}

If all existing preheater and precalciner kilns were equipped with ORC systems, it is estimated that about 1 billion kWh could be saved at 1982 production levels. This represents an annual electricity savings of about $12 \%$. As more preheaters and precalciners are installed, the potential for energy savings with this technology will increase.

\subsection{POSSIBLE BARRIERS}

The economics of ORC systems currently preclude their adoption for lowtemperature waste heat recovery. The major technical barrier to adopting steam Rankine or ORC systems by the cement industry is the scale buildup and meta? corrosion problems resulting from the constituent: in the kiln off gases (Bhatty 1983; Marner 1982). Fouling and corrosion problems result in reduced system efficiency, high maintenance costs, and in some cases, system failure.

Adoption of ORC systems is further impeded by their lack of operating history in cement plants. 


\subsection{RESEARCH AND DEVELOPMENT}

This chapter provides a discussion of research and development (R\&D) opportunities which are thought to have the potential to reduce cement industry energy consumption through improvements to existing technology or through the development of new technologies. Before the R\&D opportunities are presented, an overview of the energy-related R\&D currently being conducted is presented.

\subsection{CURRENT RESEARCH}

Research and development related to conserving energy in cement-making operations is conducted primarily by 1) the Portland Cement Association with funding from its member organizations and the DOE, 2) by the DOE through its national laboratories, independent research organizations, and universities, 3) by domestic and foreign suppliers of equipment to the cement industry, and 4) by individual cement companies, both domestic and foreign.

Basic research is conducted by the Portland Cement Association through its Construction Technology Laboratories (CTL) in Skokie, Illinois. This research is funded by its member organizations in the United States and Canada or by the government. Some of the conservation-related studies that are currently under way at CTL include the following:

- extension of fly ash technology as it applies to concrete

- use of high-sulfur fuels in pyroprocessing of portland cement clinker

- use of carbonate addition to portland cement for grinding energy conservation and cement property improvement

- use of cement kiln dust in blended cements and other applications

- use of concrete products in passive solar building systems and energy conservation in buildings.

The DOE's Office of Industrial Programs is currently funding or has recently completed research in the following areas: 
- laboratory and field studies of kiln dust and coal fly ash blends (jointly funded with the Department of Transportation and performed by Valley Forge Laboratories, Inc., Devon, Pennsylvania)

- laboratory studies of catalyzed, low-temperature calcination (performed by Southwest Research Institute, San Antonio, Texas)

- study of the wear and corrosion of grinding media in ball mills (University of Minnesota)

- mathematical modeling of two-stage classification (Amax Extractive $R \& D)$

- study of improved grinding machines (Rexnord)

- investigation of high-tensile cement pastes (PCA)

- investigation of particle size control in cernent (PCA).

The major equipment suppliers have laboratory facilities in which they develop and test new equipment. In recent years, most of the innovations in energy-efficient cement-making equipment have come from equipment developers in Japan and Europe, probably due to higher energy costs in those countries. In addition, some attribute the foreign innovation partially to the fact that in Japan and in Germany the cement producers and equipment suppliers work closely in developing new equipment, whereas in the U.S. these groups tend to operate more independently. The major energy-saving technologies that have been and are continuing to be developed by these private firms include the following:

- preheater/precalciner technology

- low-pressure drop cyclones for preheaters

- high-efficiency air classification equipment

- energy-efficient finish grinding mills (roller mills, cone crushers, high-pressure roller presses)

- automatic kiln control

- fluid-bed furnaces

- advanced stationery kilns. 
With the exception of some of the advanced stationery kilns, most of the technologies were first developed overseas.

The U.S. cement industry spent $0.03 \%$ of its gross sales (about $\$ 120 \mathrm{mil-}$ lion) on R\&D in 1980 (National Materials Advisory Board 1980). Limited information from two Japanese cement companies indicates that significantly more is spent on $R \& D$ as a percentage of sales. Nihon Cement spent $\$ 8.4$ million (1.16\% of total sales) and Onoda spent $\$ 10$ million (about $1 \%$ ) on R\&D in 1983 (Huhta 1984). In addition, the Cement Association of Japan does not depend on funds from outside the cement industry as does the Portland Cement Association (Skalny, Pentecost and Ruh 1984).

\subsection{RESEARCH AND DEVELOPMENT NEEDS}

The research needs presented in this section were developed through an iterative process. First, a list of R\&D topics was compiled from earlier reports and conference proceedings. The list was then sent to several cement industry contacts. These individuals were asked to review the R\&D opportunities, to specify whether they felt that a federal role is needed to realize each opportunity, and to add or delete topics. The resulting list was then submitted to cement industry contacts, equipment manufacturers, and the PCA for review as part of the draft report.

The discussion of $R \& D$ needs in this chapter is organized around the following subject areas:

- kill thermal efficiency

- grinding methods

- waste materials utilization

- waste heat utilization

- product/process development.

R\&O currently being pursued by the private sector is identified. Estimates of the energy savings that may be realized through each R\&D opportunity are provided. These order-of-magnitude ranges are based on the energy savings calculated for the current and advanced technologies, which are summarized in Table S.1. 


\subsubsection{Kiln Thermal Efficiency}

This classification includes R\&D associated with developing new pyroprocessing equipment or with modifying existing equipment to perform more efficiently.

In this classification six R\&D areas were identified as potential R\&D candidates:

- instruments for on-line analysis

- kiln shell heat losses

- kiln feed homogenization

- advanced pyroprocessing systems

- alternate preheater/precalciner designs (private sector)

- advanced kiln control (private sector).

Equipment manufacturers are actively engaged in developing more efficient pyroprocessing systems. They are continuing to midify and introduce new precalciner designs. In addition, R\&D is being conducted to reduce the pressure drop across preheater cyclones. Lowering the pressure drop will decrease the fan power needed to operate the systems, thereby resulting in electricity savings. Several companies are developing automatic kiln control systems, including the FLS/SDR system by $F$. L. Smidth, WOKURS by KHD Humboldt Wedag, and SILTAC by Chichibu Cement of Japan.

Instruments for On-line Analysis

Instruments that could perform on-line analyses of kiln exhaust compositions, kiln temperature, or clinker quality could greatly improve control technology. Currently, the amount of bypass is calculated theoretically using data from laboratory analyses of raw materials. An automatic on-line clinkerquality sensor could function as an analog to a microscopic analyzer to save much of the energy that is currently dumped in the bypass stream (Biege 1978). To control burning efficiency, high-temperature sensors are needed. Instruments developed for these functions would have to be able to withstand high temperatures and abrasive environments.

On most kilns, firing rate and burner configuration are adjusted manually, rather than with automatic controls. Most available instruments do not give a 
signal that can be directly linked to combustion control. The results of lessthan-optimal firing may include product quality problems, refractory damage, and fuel waste. The ultimate measures of kiln performance do not provide immediate feedback to the operators. These measures include the following (Doyle 1983):

- lab analyses of clinker quality (at least two hours after clinker formation)

- cement strength (days later)

- refractory life (months later).

Kill torque can be used as a relative measure of temperature since the load tends to climb higher on the wall as the temperature increases, thus increasing the torque required to rotate the kiln (Doyle 1983). However, kiln torque is reported to not respond fast enough to provide the "real-time" information needed for optimal control (Sheridan and Skjoth 1983).

Performance measures that are more immediate include visual assessment and temperature measurement with optical pyrometers. Visual assessment is highly subjective, requires a high degree of operator experience, and does not provide reliable information on a continuous basis. Optical pyrometers can provide a good measure of temperature if the view of the burning zone is not obstructed. In many cases, the excessive dust, particularly in dry kilns that are coalfired, interferes with effective operation of optical pyrometers (Sheridan and Skjoth 1983).

Some cement plants have begun to use instruments that measure $\mathrm{NO}_{x}$ concentration to indicate burning-zone temperature. However, N0 $x$ concentration is influenced by factors other than burning-zone temperature, such as burner configuration, burner setting, and $\mathrm{O}_{2}$ concentration. Initial indications are that this type of monitoring system may prove useful in detecting problems within the kiln or in setting optimal burner configurations.

Based on energy savings reported for advanced $x j l n$ control systems (p. 4.19), an estimated 5 to 10 trillion Btu/year may result from improved on-line instruments. 


\section{Kiln Shell Heat Losses}

A considerable amount of heat is lost through the shell of a cement $k i l n$, particularly near the burning zone. Even for an efficient precalciner kjin, the shell losses may be as much as $0.2 \times 10^{6} \mathrm{Btu} / \mathrm{ton}$ of clinker (Gartner and Tresouthick 1982). Shell losses are much higher in older, smaller kilns in which the production rate is lower relative to the kiln surface area. Research opportunities related to shell losses may include investigating new refractory materials, developing equipment to recover the low-temperature, diffuse waste heat for raw material drying, or developing pyroprocessing systems which have a lower surface-area-to-production ratio. Potential energy savings are estimated to range from 15 to 20 trillion Btu/year.

\section{Kiln Feed Homogenization}

Poor kiln feed homogeneity is reported to be a serious constraint to kiln thermal efficiency. Current technology uses air to perform raw material blending in silos. The energy efficiency of these systems is low and the capital costs are high. Research is needed to develop an efficient, low-energy blending system for $k i 1 n$ feed. This may result in an annual savings of 1 to 2 trillion Btu.

\section{Advanced Kiln Concepts}

Although U.S. industry was responsible for the invention of the rotary kiln in the late 19th century, the development of most new, energy-efficient pyroprocessing systems is being vigorously pursued by European and Japanese firms. Advanced pyroprocessing systems may save 25 to 35 trillion Btu/year in the long term. Some of the long-term opportunities in this area are allelectric kilns and advanced fluidized-bed concepts. Each is briefly discussed below.

Electric kiln Systems. All-electric kiln systems may have future potential in areas with relatively low electricity costs. The advantages of the all-electric kiln are the ability to produce low alkali cements, better process control, and low emissions. It may also be possible to combine fossil firing with electric heating. The fossil fuels would be used for precalcining and preheating and the electricity would be used to heat the rotary kiln. This 
type of system would have low kiln heat losses because essentially no gases other than alkali vapors and carbon dioxide would be generated in the $k i l n$, and the system would be able to operate efficiently at $100 \%$ bypass for the removal of the alkalies (Gartner and Tresouthick 1982).

Advanced Fluidized-Bed Kilns. The advanced fluidized bed conceptualized by Bendy Engineering (Wilson 1984) has the potential for significant reductions in pyroprocessing fuel use. This conceptual design overcomes the shortcomings of earlier fluidized-bed designs that wasted the sensible heat in the clinker and the exhaust gases. The design also has the potential to significantly lower radiation losses because the stationary design allows the refractories to be optimized. Because this design is only in the conceptual stage, much work would have to be done to address the technical issues involved. The following engineering issues have been identified as the immediate research needs for this technology (Wilson 1984):

- the configuration and size of process vessels

- the blower pressure and flow rate

- the design of gas locks to seal against gas flow while allowing materia flow

- methods of adding and withdrawing materials from the beds

- the optimal materials of construction (refractories, insulation, etc.)

- conirol methods. Candidate technology transfer topics that were identified include the followinu:

- advinced kiTn control

- cha $n$ systems.

\subsubsection{Grinding Methods}

Improvements in grinding equipment, particularly for finish grinding, offer siunificant potential (between 1 and 10 trillion Btu/year) for reducing fuel and power use. Saving energy in this area is regarded as a high priority by the cement industry, particularly in view of continually escalating 
electricity prices. Continued development of the following was frequently cited as important to saving grinding energy:

- computer control of grinding processes

- particle size distribution control

- energy-efficient grinding apparatus.

Many of the major equipment suppliers are continuing to conduct applied research related to developing the hardware aspec:s of these technologies, particularly improved air classifiers, roller mills, high-pressure roller presses, and cone crushers. Much of the development work is occurring in foreign countries, where the equipment developers and cement plants work together on equipment development.

Basic research and technology transfer were cited as appropriate roles for DOE in this area. Basic research needs identified include the following:

- collection of wear and abrasion data for var ous grinding media and mill linings

- comparison of two-stage classification systers

- basic studies of particle-size distribution control.

Technology transfer topics that were suggested include the following:

- separation in finish grinding

- classified liners

- roller versus ball mills

- chrome alloy balls versus standard forged balls.

\subsubsection{Waste Materials Utilization}

This classification includes R\&D associated with the use of waste materials as raw materials or fuel.

Blended Cements

Basic research on blended cements has been conducted by the Portland Cement Association, the National Bureau of Standards, BuMines, the Army Corps of Engineers, the Departments of Energy and Transportation, and at least one 
private corporation. (a) Recent research in this area includes a study jointly funded by $D O E$ and the Department of Transportation to develop and characterize a range of cement-kiln dust, coal fly ash, and aggregate materials that could be used to produce concrete for road beds. The mixtures would conserve energy by reducing the amounts of asphalt and portland cement used for this application.

A preliminary investigation of the compressive strength, time to set, and workability of various combinations of cement-kiln dust, cement-kiln dust/fiy ash, and cement-kiln dust/fly ash/slag was recently completed by the Portland Cement Association (PCA). Adding kiin dust to cement was found to decrease the strength, time to set, and workability compared to portland cement. However, adding $s$ ag or fly ash showed better or comparable characteristics to cement or cement/kiln dust blends (Bhatty 1984). PCA plans to study the effects of chloride on reinforcement in concrete when high-chloride kiln dusts are used. The effects of high-chloride dusts on conduit buried in concrete must also be determined.

General areas of further research were identified:

- characterize fly ash and hydration mechanisms

- establish performance data for a variety of dusts, cements, fly ashes and slags in mortars and concretes (particularly durability to freezing and thawing and resistance to sulfate attack)

- perform case studies of the economic feasibility of using waste materials in concrete preparation

- investigate possible changes to ASTM and NBS cement specifications and standards.

At 1982 oroduction levels, substituting waste materials for $10 \%$ of portland cement in concrete would save about 30 trillion Btu/year. Substituting waste material; for $30 \%$ would save about 90 trillion Btu/year.

(a) Sumna 1 Corporation, Panama City, Florida, has developed a cementitious material (Estacron) using coal fly ash, kiln dust, and polyethylene from food packaging. 
Waste-Derived Fuels

Investigating the use of alternative kiln fuels, such as solid wastes and municipal sludges, was deemed to be an appropriate candidate for federal involvement. Several types of waste materials not currently used as fuels in the U.S. have potential for replacing traditional fuels in cement manufacturing. Investigating the potential of crank-case oil, waste solvents, waste cellulosics, by-product hydrogen, as well as municipal waste, has been suggested (Frohnsdorff et a1. 1979). The impacts of using these fuels on product quality, process control (particularly potential buildup problems), and pollution control need to be investigated. In higher-grade fuel, an annual savings of 6 to 20 trillion Btu could be realized by substituting waste-derived fuels at a rate of $10 \%$ to $30 \%$.

\subsubsection{Waste Heat Utilization}

An estimated 3.5 million Btu of excess heat jer ton of clinker are lost from pyroprocessing operations. The major barrien to the recovery of this heat is the lack of adequate information and technology for dealing with these hightemperature, dirty waste gases. The opportunities that were identified for federally funded R\&D in this category are as follows:

- develop high-temperature filters for kiln exhausts

- investigate bujld-up problems.

Thermal energy storage and transport were cited as inappropriate because they have shown little promise in the past. Research in this area could potentially save 8 to 20 trillion Btu annually by removing the technical barriers to the adoption of steam and organic Rankine bottoming systems.

\section{High-Temperature Filters for Kiln Exhausts}

Because the heating and cooling operations in the cement industry are direct contact processes, waste gases are dust-laden and highly abrasive. Wet kiln exhausts are estimated to contain between $3 \%$ and $18 \%$ dust, and exhausts from dry kilns are estimated to contain between $25 \%$ and $35 \%$ dust (Sapp 1981). The constituents of these kiln dusts are responsible for buildups in kilns, in 
preheaters, in waste-heat boilers, and on induced-draft fan blades (Bhatty 1981). These buildups reduce heat transfer efficiency and may lead to equipment plugging.

Filters could potentialiy be used to clean dust-laden exhausts before they enter the heat recovery equipment. This would help to mitigate the fouling problems currently associated with waste-heat boilers. Filters could also be used in conjunction with the preheater bypass to remove alkali constituents and allow recovery of the high-temperature waste heat from this source.

Fitters developed for these purposes must have the capability to survive the high temperatures associated with kiln exhausts. The filters must efficiently remove dust particles without appreciably lowering the stream temperature.

Fabric filters have proven high efficiency at low temperatures. Benchscale tests have been conducted to demonstrate the feasibility of using ceramic fabric filters to collect coal fly ash particles at high temperatures. In these tests, filtering efficiencies of up to $97.9 \%$ were achieved at a temperature of about $1500^{\circ} \mathrm{F}$ (Furlong and Shevlin 1981).

Buildup Problems

Gas-side fouling in cement plants results in increased capital and operating costs, lost production, and wasted energy. The annual cost of fouling to the cement industry is estimated to be about $\$ 0.24$ billion, with about half of this attributable to the cost of wasted energy (Marner 1982). Preliminary work has been conducted by the Portland Cement Association to characterize deposits that occur in preheaters, kilns, waste heat boilers, and on induced draft fan blades and to postulate deposit formation mechanisms (Bhatty 1981, 1983). However, much additional work is needed to fully understand fouling mechanisms in cement plants before the considerable amount of heat currently being wasted can be used.

Several specific high-priority activities for investigation were identified, in:luding the following:

1. characterize high-temperature kiln exhausts 
2. characterize fouling deposits (particularly in the calcination zone of preheaters and the burning zone of kilns)

3. study mechanisms of deposit formation (particularly the formation of spurrite, calcium silico sulfate, and calcium carbonate)

4. develop deposit prevention measures.

In addition, several medium-priority research activities that are considered appropriate for federal involvement were identified: 1) characterize deposits on induced draft fan blades, in the preheating zone of wet kilns, and in chain sections, 2) study alkali salt deposit formation mechanisms, 3) study the effect of alkali, sulfate, chloride, fluorides, as well as other minor elements on subsequent deposit formations, 4) develop deposit removal techniques, and 5) investigate refractory deterioration.

\subsubsection{Process/Product Development}

This classification includes research opportunities associated with altering the chemical or physical properties of the cement product or with developing new processes to save energy. General activities that have been identified in this area include the following:

- investigate optimal raw material mixes with respect to cement quality requirements

- investigate cement specifications

- develop high-tensile cements

- catalyzed, low-temperature calcination. Optimal Raw Mixes

Raw material properties could be studied (both separately and in kiln feed blends) in tandem with a study of cement clinker properties to improve the basis for predicting cement quality from raw material properties. This type of basic information is regarded as necessary to match the cement quality requirement with energy-savings actions such as 1) shorter burning time, and/or 2) lower burning temperature. 


\section{Cement Specifications}

In many cases, current specifications and standards act as barriers to implementing energy-conserving technologies in the cement industry. Investigation is needed to determine how cement specifications (particularly those on alkali content and cement fineness) can be modified to optimize energy savings and cement quality. The possible use of performance specifications to replace the current prescriptive specifications should be investigated. Relaxing the alkali and the fineness specifications is estimated to save 10 to 15 trillion Btu/year.

\section{High-Tensile Cements}

A need for research to develop high-tensile cements has been noted. Imperial Chemical Industries of Britain developed a high-strength portland cement that could reportedly be used for items such as helical springs and bottle caps. The cement is produced by eliminating the large pores, which are normally found in cements based on calcium silicate, calcium aluminate and calcium carbonate, through the use of a rheological control agent in the wet cement mix. This cement is reportedly very expensive and it loses tensile strength above abost $200^{\circ} \mathrm{F}$. If a high-tensile cement could be developed, while it would not likely save energy in the cement industry, it could have the potential of reducing national energy consumption by replacing more energy-intensive materials, such as mild steel or mid-strength aluminum.

\section{Catalyzed, Low-Temperature Calcination}

Southwestern Research Institute is currently researching this area for DOE. In the first phase, more than 100 catalyst samples were screened. Catalysts prepared by fusing calcium carbonate with potassium carbonate and sodium carbonate appeared to be the most effective in promoting the limestone calcination reaction. Work currently being conducted involves 1) examining the efficiency of the catalyzed process with limestone of various particle sizes, variations in temperature, and a tumbling/mixing environment, 2) performing a bench-scale energy balance study, and 3) providing a preliminary evaluation of energy and economic issues. This work is scheduled to be completed in Apri? 1985 (OIP 1983a). This process is estimated to be able to reduce the thermal energy requirement by as much as $25 \%$ (0IP 1983a). 


\section{REFERENCES}

A. D. Little, Inc. 1976. Environmental Considerations of Selected Energy Conserving Manufacturing Process options: Volume X: Cement Industry Report. PB-264276. National Technical Information Service, Springfield, Virginia.

Bhatty, M. S. Y. 1981. "Cement Kiln System Buildups." Proceedings of the 16th International Cement Seminar. Maclean-Hunter Publishing Corp., Chicago, Illinols.

Bhatty, M. S. Y. 1983. "Composition of Waste Heat Boiler Buildups in Cement Kiln Systems." ASME/JSME Thermal Engineering Joint Conference 1983 (Proceedings), volume I. pp. 553-557.

Bhatty, M. S. Y. 1984. "Use of Cement-Kiln Dust in Blended Cements." World Cement. 15(4):126-134.

Biege, N. W. and L. J. Parsons. 1978. "Bypass Systems for Preheater and Flash Calciner Kilns." Pit \& Quarry. PP. 91-96.

Boldyrev, S. July 1983. "The Soviet Cement Industry." Rock Products. $86(97): 52-54$.

Breindel, B., F. M. Collamore and J. L. Goetz. 1979. "Multi-Megawatt Organic Rankine Engine for Power Generation in the Cement Industry." IEEE, New York, New York.

Brown, P. W., et a1. February 1976. Energy Conservation through the Facilitation of Increased Blended Cement Use. NTIS No. PB-251-218. National Bureau of Standards, U.S. Department of Commerce, Washington, D.C.

Bureau of Mines. 1972-1982. Minerals Yearbook. Bureau of Mines. U.S. Department of the Interior, Washington, D.C.

Bureau of Mines. 1984. Mineral Commodity Summaries. Bureau of Mines, U.S. Department of the Interior, Washington, D.C.

Burriss, C. S. 1981. "Atlantic Cement's New Slag Facility." Proceedings of the 16th International Cement Seminar. Maclean-Hunter Publishing Corp., chicagc, ITTinois.

Dikeou, T. 1980. "Cement." In Mineral Facts and Problems. Bureau of Mines, Department of the Interior, Wasfington, D.C.

Dodds, J. October 2, 1984. Scrap Tire Fuel for Cement Kilns: Exchange Meeting Summary. CONF-8410167. EG\&G Idaho, Inc., Idaho Falls, Idaho. 
Dombrowse, H., B. Hoffmann and W. Scheibe. 1982. "Mode of Action and Possibilities for Use of Grinding Aids." Zement-Kalk-Gips. Translation No. 11/82. pp. 571-580.

Doyle, B. W. 1983. "The Use of NoX as Kiln Temperature Indicator." Proceedings of the 19th International Cement Seminar. Maclean-Hunter Publishing Corp., Chicago, ITlinois.

Energy Information Administration. Monthly. Monthly Energy Review. DOE/EIA-0035, U.S. Department of Energy, Washington, 0.C.

Fassbender, A. G., et al. August 1982. Energy Efficient Industrial Technology in Japan: A Compendium. GRI-81/0084. Prepared by Pacific Northwest Laboratory for the Gas Research Institute, Chicago, Illinois.

Frigione, G. 1983. "Effect of Fineness of Raw Mix Components on Clinkerization." World Cement. 14(6):214-218.

Frigione, G., F. Zenone and M. V. Esposito. 1983. "The Effect of Chemical Composition on Portland Cement Clinker Grindability." Cement and Concrete Research. 13:483-492.

Frohnsdorff, G., et al. (eds.). May 1979. Possible Contributions of Cement and Concrete Technology to Energy Conservation. PB-295 584. National Engineering Lab, National Bureau of Standards, Washington, D.C.

Fuel and Energy Consultants, Inc. January 1982. An Assessment of Energy Saving Technologies with Potential for Applications in U.S. Industries. Prepared for the U.S. Department of Energy, Washington, D.C.

Furlong, D. A. and T. S. Shevlin. January 1981. "Fabric Filtration at High Temperature." Chemical Engi neering Progress.

Garrett, H. M. February 1980. "Coal and the Cemert Industry." Mining Engineering. pp. 188-197.

Garrett, H. M. and J. A. Murray. 1974. Improving Kiln Thermal Efficiency. Raymond Kaiser Engineers, Oakland, California.

Garrett-Price, B. A., J. S. Barnhart, and E. J. Eschback. 1982. Performance and Market Evaluation of the Bladeless Turbine. PNL-4412, Pacific Northwest Laboratory, Richland, Washington.

Gartner, E. M. and S. W. Tresouthick. 1982. "Potential for Energy Conservation in the U.S. Cement Industry." World Cement Technology. 13(5).

Golden, R. 1984. "Fluidized Bed Combustion for Raw Materials and Coal Processing." World Cement. 15(4):121-125. 
Harrop Industries, Inc. Undated. "Harrop Osciplatem Calciner." Brochure from Harrop Industries, Inc., Columbus, Ohio.

Hartley, J. N., K. A. Priestly and 0. J. Wick. October 1978. "Chemical Additives for Ore Grinding: How Effective are They?" Engineering and Mining Journal. p. 105-111.

Howlett, C. and H. M. Garrett. May 1981. "Precalciners Today." Presented at the IEEE Cement Industry Technical Conference, Lancaster, Pennsylvania.

Huhta, R. S. 1984a. "We Tour Japan's Cement Industry." Rock Products. $87(10): 50-A-50-H$.

Huhta, R. S. August 1984b. "Roller Mills vs. Tube Mills." Rock Products. $87(8): 43-44$.

Johnson, W. and S. T. Absalom. 1982. Cement. Preprint from the 1982 Bureau of Mines Minerals Yearbook, United States Department of the Interior, Washington, D.C.

Johnson, W. and R. Lacroix. 1984. Directory of Cement Producers in 1983. U.S. Department of the Interior, Bureau of Mines, Washington, D.C.

Klumpar, I. V., F. N. Currier, and T. A. Ring. May 1984. "Air Classifiers." Presented at the Belgian Engineering Society Meeting, Brussels. Sturtevant, Inc., Boston, Massachusetts.

Kokubu, Y. and T. Katsuki. 1983. "Energy Savings Improvement in a Dry-Process Cement Plant." Proceedings of the 19th International Cement Seminar.

Maclean-Hunter Publishing Corp., Chicago, Illinois.

Kreisberg, A. J., and B. H. Schonbach. May 1983. "Economic Feasibility of Wet-to-Dry Conversion in North America." Proceedings of the 25th Annual IEEE Cement Industry Technical Conference. IEEE, New York, New York.

Labahn, 0. and B. Kohlhaas. 1983. Cement Engineer's Handbook. Bauverlag GMBH, Wiesbaden, Federal Republic of Germany.

Lokanc, L. 1983. "Moisture Reduction in Kiln Feed Slurry." Proceedings of the 19th International Cement Seminar. Maclean-Hunter Publishing Corp., Chicagc, Illinois.

Marner, w. J. September 1982. An Assessment of Gas-Side Fouling in Cement Plants. DOE/ID-12138-2. Prepared for the Department of Energy by the Jet Propulsion Laboratory, Padadena, California.

McIvor, F. E. June 1983. "Effects of Speed and Liner Configuration on Ball Mill Performance." Mining Engineering. pp. 617-622.

National Materials Advisory Board (NMAB). 1980. The Status of Cement and Concrete R\&D in the United States. MMAB-361. Washington, D.C. 
Office of Industrial Programs. July 1983a. Energy-Efficient Lime Production: Catalyzed, Low-Temperature Calcination Process. Project Description Sheet, U.S. Department of Energy, Washington, D.C.

Office of Industrial Programs. July 1983b. Low-Energy Cement Production: Kiln Dust and Coal Fly Ash Blends. Project Description Sheet, V.S. Department of Energy, Washington, D.C.

Onuma, E. 1983. "A New High-Efficiency Classifier as Applied to the Cement Industry." 19th International Cement Seminar Proceedings. Published by Maclean-Hunter Publishing Corp., Chicago, Illinois.

Onuma, E. and T. Furukawa. 1984. "0-SEPA: A New High-Performance AirClassifier." World Cement. 15(1):13-24.

Pit \& Quarry. March 1983. "Cogeneration Project will Provide Electricity for California Cement Plant." 75(9):64.

Portland Cement Association. June 1975. Energy Conservation Potential in the Cement Industry. PB-249 159. Prepared for the Federal Energy Administration, Washington, D.C.

Portland Cement Association. 1980. U.S. and Canadian Portland Cement Industry: Plant Information Summary. Skokie, ITTinois.

Portland Cement Association. 1984. U.S. and Canadian Portland Cement Industry: Plant Information Summary. Skokie, Illinois.

Power. January 1985. "Japanese Cement Plant Reaps Saving from Automated DualPressure Recovery." 129(1):80-82.

Reber, L. April 1984. "Giant Portland Burns Waste 0il in Kiln." Rock Products. $87(4): 44$.

Redfern, J. D. 1983. "Welcoming Address." Proceedings of the 25th Annual IEEE Cement Industry Technical Conference. San Antonio, Texas.

Resource Planning Associates, Inc. 1978. Industrial Markets for Organic Rankine Bottoming Systems. Prepared for the 1.5 . Department of Energy, Washington, D.C.

Rock Products. October 1983. "Stats Verify '82 was a 'Bummer'." 86(10):48C.

Roy, R. October 1983. Energy Report U.S. Portland Cement Industry. Portland Cement Association, Skokie, Illinois.

Sapp, J. E. June 1981. Energy and Materials Flows in the Cement Industry. $\mathrm{ANL} / \mathrm{CNSV}-17$. Argonne National Laboratory, Argonne, Illinois.

Segal, R. April 1984. "Kiln Fuel: Rice Hulls, Waste 0ils." Rock Products. $87(4): 42-44$. 
Sheridan, S. E. and P. Skjoth. May 1983. "Automatic Kiln Control at Oregon Portland Cement Company's Durkee Plant Utilizing Fuzzy Logic." Presented at the 25th IEEE Cement Industry Technical Conference, San Antonio, Texas.

Shimojima, K., et al. 1984. "Newly Developed Roller Mill for Cement Clinker Grinding." World Cement. 15(7):230-232.

Skalny, J. P., J. L. Pentecost and E. Ruh. 1984. "The Japanese Cement Industry." Ceramic Bulletin. 63(9):1127.

Srinivasa, V. P. 1983. "The Million Dollar Grinding Mill: Is It for You?" Presented at the SME-AIME Fall Meeting, Salt Lake City, Utah, October 19-21, 1983.

Trovaag, K. March 1983. "Hazardous Waste Incineration in Cement Kiln." Wor\}d Cement. 14(2):59,61-62.

United Technologies Corporation. January 1980. Cogeneration Technology Alternatives Study (CTAS): Volume II: Industrial Process Characteristics. DOE/NASA/0030-80/2. United Technologies Corporation, South Windsor, Connecticut.

Wilson, J. 1984. "Consider the Fluid Bed." Rock Products. $87(2): 48 \mathrm{~A}$. 
APPENDIX A

CEMENT-MAKING PROCESSES 


\section{CEMENT-MAKING PROCESSES}

This appendix provides a brief overview of the cement-making process. The basic processing steps in cement production are 1) quarrying and transporting, 2) crushing and grinding, 3) pyroprocessing, 4) clinker cooling, and 5) final grinding.

QUARRYING AND TRANSPORTING

Calcareous rock $\left(\mathrm{CaCO}_{2}\right)$ is the principal component of hydraulic cement, comprising $85 \%$ of the raw material requirement. The primary sources of calcareous rock are limestone, cement rock (including marl), and oystershell and coral. Noncalcareous materials needed to manufacture clinker include silica $\left(\mathrm{SiO}_{2}\right)$, alumina $\left(\mathrm{Al}_{2} \mathrm{O}_{3}\right)$, and iron oxide $\left(\mathrm{Fe}_{2} \mathrm{O}_{3}\right)$. Most of the raw materials used in the cement industry are quarried using surface mining techniques, although a few limestone and gypsum deposits are mined underground.

In 1982, the U.S. cement industry used $107.08 \mathrm{million}$ tons of raw materials to produce 60.254 million tons of clinker (BuMines 1982). The total of each raw material used by the industry is given in Table A.1.

Equipment used in the quarrying and transporting step includes the following:

- bulldozers and scrapers or front-end loaders with trucks to remove overburden

- rotary drills and percussion drills for drilling blast holes

- electric or diesel power shovels, dragline excavators, and front-end loaders, with bucket capacities of $1-1 / 2$ to 15 cubic yards, to load broken stone into trucks

- diesel trucks to transport the rock. 
TABLE A.1. Raw Materials Used in U.S. Portiand Cement Manufacture (BuMines 1982)

Raw Material

Ca1careous:

Limestone (including aragonite, marble, chalk)

Cement Rock (includes marl)

Oystershell and coral

Argillaceous:

Clay

Shale

Other (staurolite, bauxite, aluminum dross

pumice, alumina, volcanic material, etc.)
Million Tons

71,307

18,593

1,773

5,007

3,282

209

Siliceous:

Sand and calcium silicate

1,568

Sandstone, quartzite, other

508

Ferrous:

Iron ore, pyrites, millscale, other iron-bearing materials

958

Other (added during finish grinding):

Gypsum and anhydrite

Blast furnace slag

Fly ash

other

108

Total

CRUSHING AND GRINDING

Crushing and grinding operations reduce the size of the raw materials and blend the various materials prior to pyroprocessing. The rock is first crushed to about six-inch-diameter pieces in gyratory, jaw or roller crushers. Then, it is further crushed in cone crushers or hammer mills to grinding mill feed size (less than 0.75 -inch diameter). 
During grinding, crushed calcareous rock is interground with noncalcareous materials. Two processes are used to grind raw materials: the wet process and the dry process. In the dry process, raw materials are dried and pulverized into a powder, whereas in the wet process water is added during grinding to produce a slurry containing about 65\% solids (Dikeou 1980). Ball mills and rod mills have typically been used for grinding. For dry process grinding in these mills, raw materials must first be dried, usually in a rotary dryer. In many new dry-process plants, roller mills are replacing rod and ball mills, and the material is dried during grinding with waste heat exhausted from the kilns.

PYROPROCESSING

Pyroprocessing involves heating the feed as high as $2900^{\circ} \mathrm{F}$ to produce clinker. In wet kilns, moisture is driven off in the first temperature zone. In both processes, calcium carbonate $\left(\mathrm{CaCO}_{2}\right)$ is converted to calcium oxide (CaO), alkalies are vaporized, and any organic material is burned in a temperature zone up to $1800^{\circ} \mathrm{F}$. Clinkering takes place at about 2700 to $2900^{\circ} \mathrm{F}$. The iron oxide in the feed materials acts as a flux to lower the temperature required to form clinker.

The chemical reactions that occur are shown in Table A.2 along with the temperatures at which the reactions occur as the feed moves through the kiln. Calcium carbonate (primarily from limestone) decomposes to release carbon dioxide, leaving calcium oxide to react with clay, which is the source of silicon dioxide, to produce dicalcium and tricalcium silicate. Calcium carbonate and the salcium oxide react exothermically with the aluminosilicates.

Pyroprocessing is the most energy-intensive step in manufacturing cement. Fossil fuels are burned and the hot combustion gases directly contact the feed materials as the two streams move countercurrently through the kiln. Table A.3, which lists the theoretical heat requirement to produce cement clinker, shows that the theoretical heat requirement for producing cement is about 1.5 million Btu/ton of clinker.

Two types of kilns are used to produce clinker. Vertical (or shaft) kilns are common in Europe and other countries, whereas rotary kilns are used exclusively in the United States. Rotary kilns have larger capacity 
TABLE A.2. Wet and Dry Process Reaction Temperatures

(Sapp 1981)

Reaction

Free water evaporated

More firmly bound water of hydration

liberated from clay, the Si source

$\mathrm{CaCO}_{3}$ starts decomposing to $\mathrm{CO}_{2}$ and $\mathrm{CaO}$

$\mathrm{Ca}$ and $\mathrm{Si}$ sources react to form $\mathrm{C}_{2} \mathrm{~S}(\mathrm{a})$ and $\mathrm{C}_{3} \mathrm{~S}(\mathrm{~b})$

Beginning of fusion
Temperature $\left({ }^{\circ} \mathrm{F}\right)$

212

932

1652

$1652-2192$

$2282-2336$

(a) 3Ca0.SiO

(b) $2 \mathrm{Ca}$. SiO

TABLE A.3. Theoretical Heat Requirement to Produce Cement Clinker (PCA 1975)

Thousand Btu/ton

of Clinker

Heat Absorbed:

Heating Raw Material from $68-842^{\circ} \mathrm{F} \quad 612$

Dehydration of Clay Materials 144

Heating Material from $842-1652^{\circ} \mathrm{F}$

Dissociation of $\mathrm{CaCO}_{3}$ a $1652^{\circ} \mathrm{F}$

Heating Calcined Feed from $1652-2552^{\circ} \mathrm{F} \quad 450$

Net Heat of Fusion

$\begin{array}{ll}\text { Total } & 3708\end{array}$

Heat Evolved:

Crystallization of Dehydrated Clay 36

Heat of Formation of Cement Compounds 360

Cooling Clinker from $2552-68^{\circ} \mathrm{F} \quad 1207$

Cooling Carbon Dioxide from 1652-68 ${ }^{\circ} \mathrm{F}$

Cooling Steam from $842-68^{\circ} \mathrm{F}$ including Condensation 72

Total $\underline{2196}$

Net Theoretical Heat Required 1512 
capabilities than vertical kilns. Rotary kilns can be used in both the wet and the dry process, whereas vertical kilns are limited to dry feed materials only.

Four basic rotary kiIn configurations are used to produce clinker in the United States: 1) wet kiln, 2) dry kiln, 3) dry kiln with preheater, and 4) dry kiln with precalciner. In each case, the kiln consists of a refractorylined, cylindrical, steel shell that rotates around an inclined axis. Feed materials enter the top of the kiln and are converted by gravity to the lower end where combustion occurs. Kiln sizes range from 6 feet in diameter and 120 feet long to 25 feet in diameter and 760 feet long, and rotate at 50 to 90 revolutions per hour (Dikeou 1980).

In general, the wet process requires longer kilns since additional heat transfer area must be provided to evaporate the water from the slurry. As much as one-fourth the length of the wet kiln contains hanging chains to facilitate heat transfer in the evaporation zone. Because of the need to evaporate water from the slurry, the energy requirements of the wet kiln are higher than that of other kilns. Average kiln energy use in the wet process is $5.6 \mathrm{million}$ Btu per ton of clinker produced (Roy 1983). In 1982, about $42 \%$ of the operating cement kilns used the wet process and produced about $40 \%$ of total annual cement production (Roy 1983).

About 58\% of the operating kilns in 1982 used the dry process, which produced $60 \%$ of the total output of the cement industry. Out of a total of 274 kilns operating in 1983, 153 used the dry process. Sixty of these had preheaters, 20 of which were precalciners (PCA 1984). Kiln capacities of preheater or precalciner kilns range from 600,000 to $1,400,000$ tons/year. Dry kilns require an average of $4.1 \mathrm{million}$ Btu to produce one ton of clinker. The average preheater cement plant used 4.5 million Btu per ton of output in 1982 , while the most efficient preheater plant used only 3.3 million Btu per ton of cement. Fuel efficiencies of precalciners are reportedly 3 to $6 \%$ better than a four-stage preheater alone (Howlett and Garrett 1981).

CLINKER COOLING

Hot clinker is rapidly air-quenced from about $2500^{\circ} \mathrm{F}$ to $150^{\circ} \mathrm{F}$ as it is discharged from the kiln. Three types of coolers are used: 1) grate coolers, 
2) planetary coolers, and 3) separate rotary coolers. In the U.S. most clinker is air cooled in a traveling grate or reciprocatirg grate cooler in which air is blown through the moving bed of clinker. The planetary cooler consists of several tubes mounted around the kiln close to the clinker outlet. The clinker and air flow countercurrently through these tubes. The planetary cooler is not as efficient as the grate-type coolers (clinker may exit planetary coolers at temperatures around $250^{\circ} \mathrm{F}$ ). Rotary coolers consist of revolving cylinders following the rotary kiln. These are the oldest type of clinker coolers.

A portion of the heated cooling air is used as secondary combustion air in the $k i 1 n$. The percentage of air used for this purpose ranges from about $45 \%$ for the wet process to about 12\% for the precalciner process (Marner 1982). The remaining portion of the heated air, which is at a lower temperature than that recovered for use as combustion air, is generally discharged after removal of particulates in a baghouse. This is generally referred to as vented air. Vented air temperatures range from about $280^{\circ} \mathrm{F}$ in the wet process to $400^{\circ} \mathrm{F}$ in the preheater or precalciner processes (Marner 198:2).

FINAL GRINDING

After cooling, the clinker is interground with about $5 \%$ gypsum to produce cement. The finish grinding of cement consumes about $40 \%$ of the electrical energy used in a typical suspension preheater kilr process (Frohnsdorff et al. 1979). Many factors affect power consumption during clinker grinding. Among these are the hardness of the clinker and the desired surface area of the product. The hardness of the clinker depends on how completely calcined the clinker is in the kiln. Clinkers with a higher free-lime content (less completely calcined) are not as hard as more completely calcined clinkers, and thus are easier to grind. The most difficult cliniker to grind may take as much as $80 \%$ more power than the easiest one (Frigione, Zenone and Esposito 1983). Ball mills are typically used for clinker grinding. 
APPENDIX B

INDUSTRY OVERVIEW 
APPENDIX B

INDUSTRY OVERVIEW

This appendix provides a brief overview of the structure, the geographic distribution, the capacity, and the production statistics of the cement industry.

INDUSTRY STRUCTURE

In 1983, 153 cement manufacturing plants were operated in the United States by 52 companies. Ten of the plants performed finish grinding only of imported, purchased, or interplant transfer of clinker. Two plants produced masonry cement and three produced calcium aluminate cement, exclusively. The remaining 37 plants produced portland cement or portland cement as well as other types of cement (Johnson and Lacroix 1984).

Lone Star Industries, General Portland, Ideal Basic Industries, GiffordHill \& Company, and Lehigh Portland Cement were the five largest companies, accounting for 35.5\% of production capacity (PCA 1984). Approximately 24\% of the clinker capacity and $25 \%$ of the finishing grinding capacity was owned by foreign concerns (Johnson and Absalom 1982). Of the five largest companies, two are under foreign ownership. General Portland is owned by Canadian Cement Lafarge $\mathrm{L}$ td. and Lehigh Portland Cement Company is owned by Heidelberger Zement AG, a West German Firm.

\section{CAPACITY}

The total clinker capacity of the U.S. portland cement industry in 1982 was 86.6 million tons and the finish grinding capacity was about 103 million tons of cement. About 39\% of this capacity used the wet process and $61 \%$ used the dry process. About $19 \%$ of the dry capacity used preheaters, $20 \%$ used precalciners, and the remainder used the long-dry process (PCA 1984). 
A11 precalciner and $94 \%$ of the preheater kilns have been constructed since 1971. These kilns have the advantages of greater capacity and more efficient energy utilization. The combined clinker capacity of the 4 largest cement kilns, which have all been built since 1980, is the same as the combined capacity of the 57 smallest xilns. Less than $25 \%$ of the kilns account for half of all capacity (PCA 1984). At the end of 1983, no new kilns were under construction (PCA 1984).

\section{GEOGRAPHIC DISTRIBUTION}

In general, cement plants are located close to raw materials and, if inland, close to their markets because both the raw materials and the finished product have high weight-to-value ratios. Cement plants which rely on land transportation of their products generally serve less than a 200-mile radius (Sapp 1981), whereas plants with access to water transportation have markets which extend beyond this limit. In general, the plants located adjacent to waterways (e.g., those on the East Coast and Hudson River, along the Great Lakes, and along the Mississippi) are among the largest in operation (A.D. Little 1976).

A11 but 10 states (a) have at least one cement plant. In recent years, the cement capacity has followed the shift of construction, employment, and population to southern and western parts of the country. The top clinker-producing states in 1983 were Texas and California with $16 \%$ and 11\% of the total domestic production, respectively (Johnson and Absalom 1982).

\section{PRODUCTION STATISTICS}

Cement is the basic binding ingredient in concrete. Cement and concrete are used in almost all types of construction, so the level of activity in these industries directly affects the output of the cement industry. About $30 \%$ of portland cement is used in connection with residential construction and $70 \%$ is

(a) Connecticut, Massachusetts, New Jersey, Rhode Island, Delaware, Minnesota, North Carolina, Vermont, New Hampshire, North Dakota. 
used in nonresidential construction activities (BuMines 1984). The construction downturn of 1980 through 1982 resulted in record low cement production levels during these years.

In 1982, the U.S. cement industry produced about 63.4 million tons of cement at a value of $\$ 4.0$ billion. In 1983, production increased to about 77 million tons of cement, of which $96 \%$ was portland cement and the remainder was masonry cement and minor quantities of calcium aluminate cement. Apparent annual clinker production capacity is estimated to be about 87 million tons and finish grinding capacity is estimated to be about 100 million tons (BuMines 1984). 
!

•

, 
APPENDIX C

SUMMARY TABLES OF INDIVIDUAL PLANT STATISTICS 
J.S. CEMENT I'LANT STATISTICS IPCA 1984, HUMINES 1984)

\begin{tabular}{|c|c|c|c|c|c|c|}
\hline PLANT & NOA & FUEL & $\begin{array}{c}\text { FINISH } \\
\text { GRINDING } \\
\text { CAPACITY } \\
{[000 \text { TONS ] }}\end{array}$ & PROCESS & YEAR & $\begin{array}{l}\text { CLINKER } \\
\text { CAPACITY } \\
\text { [TON/DAY] }\end{array}$ \\
\hline \multicolumn{7}{|c|}{ LONE STAR INDUSTRIES, INC, [GreenWICh, CT] } \\
\hline Bonner Springs, KS & 4 & $C(G)$ & 451 & $\begin{array}{l}\text { Wet } \\
\text { Wet } \\
\text { Wet } \\
\text { Wet }\end{array}$ & $\begin{array}{l}1923 \\
1923 \\
1923 \\
1955\end{array}$ & $\begin{array}{r}285 \\
285 \\
285 \\
515 \\
1370\end{array}$ \\
\hline Davenport, CA & 1 & $\mathrm{c}$ & 775 & Dry $/ \mathrm{PC}$ & 1981 & 2255 \\
\hline Greencastle, TN & 1 & $\mathrm{c}$ & 775 & Wet & 1969 & 2200 \\
\hline Houston, TX & 3 & G & 550 & $\begin{array}{l}\text { Wet } \\
\text { Wet } \\
\text { Wet }\end{array}$ & $\begin{array}{l}1931 \\
1931 \\
1956\end{array}$ & $\begin{array}{r}610 \\
610 \\
380 \\
1600\end{array}$ \\
\hline Sweetwater, TX & 3 & $\mathrm{c}$ & 545 & $\begin{array}{l}\text { Dry } / \mathrm{PH} \\
\mathrm{Dry} / \mathrm{PH} \\
\mathrm{Dry} / \mathrm{PH}\end{array}$ & $\begin{array}{l}1971 \\
1971 \\
1971\end{array}$ & $\begin{array}{r}510 \\
510 \\
560 \\
1580\end{array}$ \\
\hline Nazareth, PA & 4 & c & 658 & $\begin{array}{l}\text { Dry } \\
\text { Dry } \\
\text { Dry } \\
\text { Dry }\end{array}$ & $\begin{array}{l}1936 \\
1936 \\
1957 \\
1936\end{array}$ & $\begin{array}{r}425 \\
425 \\
515 \\
535 \\
1900\end{array}$ \\
\hline Cloverdale, $V_{A}$ & 5 & $\mathrm{C}$ & 1200 & $\begin{array}{l}\text { Dry } \\
\text { Dry } \\
\text { Dry } \\
\text { Dry } \\
\text { Dry/PH }\end{array}$ & $\begin{array}{l}1951 \\
1951 \\
1953 \\
1956 \\
1976\end{array}$ & $\begin{array}{c}425 \\
425 \\
425 \\
425 \\
1640 \\
3340\end{array}$ \\
\hline Medley, Pl & 3 & $c(G)$ & 1200 & $\begin{array}{l}\text { Wet } \\
\text { Wet } \\
\text { Wet }\end{array}$ & $\begin{array}{l}1969 \\
1969 \\
1975\end{array}$ & $\begin{array}{r}650 \\
650 \\
2150 \\
3450\end{array}$ \\
\hline
\end{tabular}




\begin{tabular}{|c|c|c|c|c|c|c|}
\hline PLANT & KOLNS & FUEL & $\begin{array}{c}\text { FINISH } \\
\text { GRINDING } \\
\text { CAPACITY } \\
{[000 \text { TONS] }}\end{array}$ & PROCESS & YEAR & $\begin{array}{l}\text { CLINKER } \\
\text { CAPACITY } \\
\text { [TON/DAY] }\end{array}$ \\
\hline \multicolumn{7}{|c|}{ [LONE STAR INDUSTRIES, CONTINUED] } \\
\hline Salt Lake City, ur & 3 & $c(\theta)$ & 420 & $\begin{array}{l}\text { Wet } \\
\text { Wet } \\
\text { Wet }\end{array}$ & $\begin{array}{l}1960 \\
1975 \\
1979\end{array}$ & $\begin{array}{r}350 \\
450 \\
450 \\
1250\end{array}$ \\
\hline Pryor, ok & 3 & $c(G)$ & 744 & $\begin{array}{l}\text { Dry } \\
\text { Dry } \\
\text { Dry }\end{array}$ & $\begin{array}{l}1960 \\
1962 \\
1980\end{array}$ & $\begin{array}{r}620 \\
620 \\
810 \\
2050\end{array}$ \\
\hline New Orleans, LA & 2 & $c(G)$ & 750 & $\begin{array}{l}\text { Wet } \\
\text { Wet }\end{array}$ & $\begin{array}{l}1963 \\
1973\end{array}$ & $\begin{array}{l}1040 \\
1140 \\
2180\end{array}$ \\
\hline Oglesby, IL & $\mathbf{b}$ & $c$ & 470 & wry & 1972 & 1500 \\
\hline Cape Cirardeau, MO & 1 & $\mathrm{c}(0)$ & 1200 & Dry /PC & 1981 & 3500 \\
\hline Pedro, OH & 1 & $\mathrm{C}$ & 260 & Dry & 1962 & 770 \\
\hline Hagerstown, Mls & 1 & C & 500 & Dry & 1971 & 1560 \\
\hline $\begin{array}{l}\text { Piltsburgh, PA } \\
\text { - ione Star llawaii }\end{array}$ & nt & $\mathrm{c}$ & 370 & Wet & 1962 & 1200 \\
\hline Ewa Heach, HI & 1 & c & 270 & Dry $/ \mathrm{PH}$ & 1972 & 830 \\
\hline TO'LAL. COMPANY & 38 & & 11,115 & & & 32,535 \\
\hline
\end{tabular}




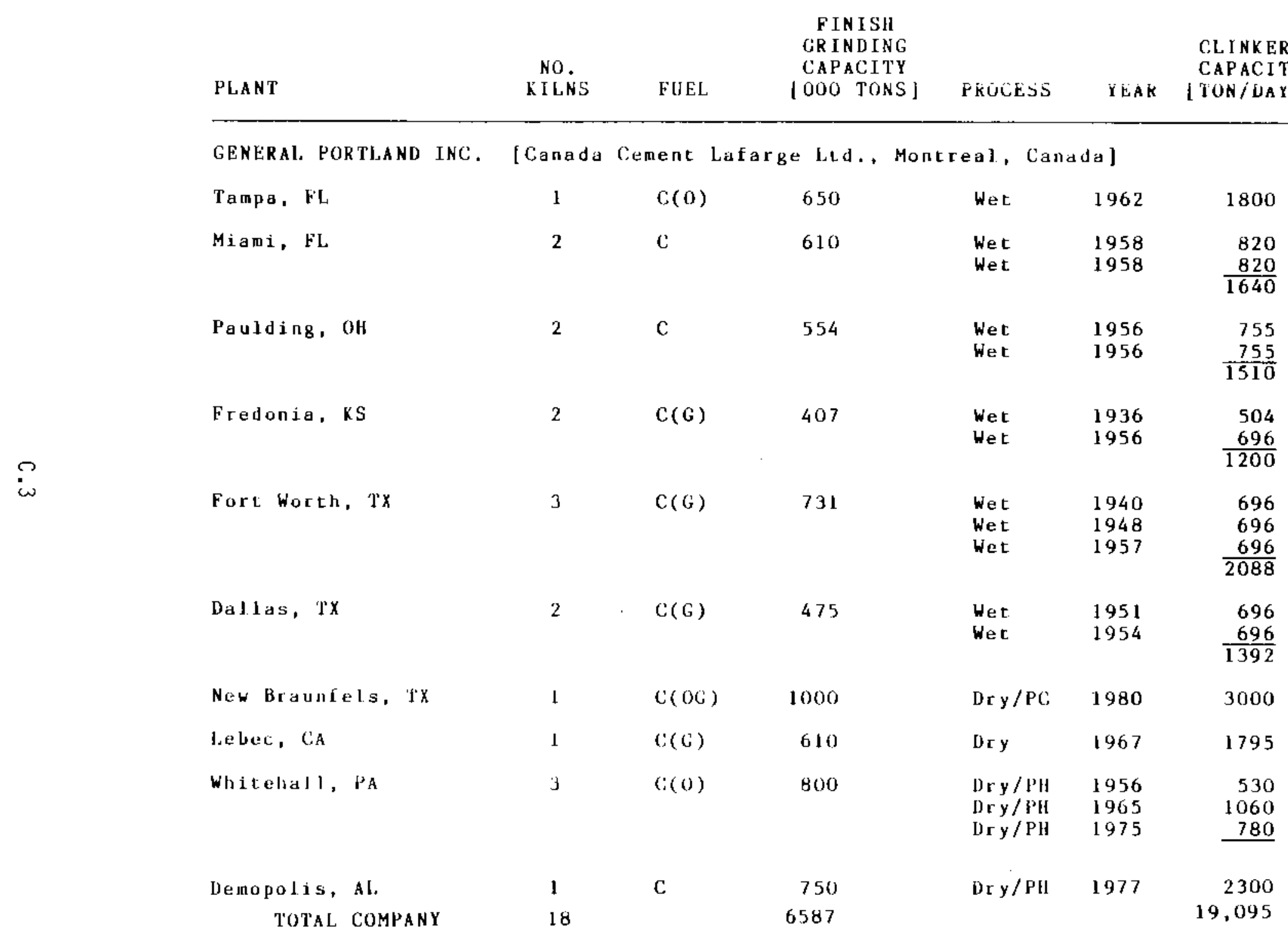




\begin{tabular}{|c|c|c|c|c|c|c|}
\hline PLANT & NOLis & FUEL & $\begin{array}{c}\text { FINISH } \\
\text { GRINDING } \\
\text { CAPACITY } \\
{[000 \text { TONS }]}\end{array}$ & PROCESS & YEAR & $\begin{array}{r}\text { CL INKER }_{+} \text {CNACIT } \\
\text { CAPAC T DAY }\end{array}$ \\
\hline IDEAL BASIC INDUST & \multicolumn{3}{|c|}{ INC. [ Denver, CO] } & & & \\
\hline Theodore, AL & 1 & $c(00)$ & 2234 & Dry / PC & 1981 & 4392 \\
\hline Saratoga, AR & 2 & $G(C)$ & 575 & $\begin{array}{l}\text { Wet } \\
\text { Wet }\end{array}$ & $\begin{array}{l}1929 \\
1929\end{array}$ & $\begin{array}{r}715 \\
392 \\
1107\end{array}$ \\
\hline Ada, $O X$ & 2 & $c(G)$ & 755 & $\begin{array}{l}\text { Wet } \\
\text { Wet }\end{array}$ & $\begin{array}{l}1958 \\
1959\end{array}$ & $\begin{array}{r}845 \\
845 \\
1690\end{array}$ \\
\hline Superior, NE & 2 & $\mathrm{c}(\mathrm{G})$ & 375 & $\begin{array}{l}\text { Wet } \\
\text { Wet }\end{array}$ & $\begin{array}{l}1968 \\
1968\end{array}$ & $\begin{array}{c}332 \\
359 \\
691\end{array}$ \\
\hline 'lijeras, NM & 2 & $c(G)$ & 060 & $\begin{array}{l}\mathrm{Dry} / \mathrm{PH} \\
\mathrm{Dry} / \mathrm{PHI}\end{array}$ & $\begin{array}{l}1959 \\
1960\end{array}$ & $\begin{array}{r}758 \\
758 \\
1516\end{array}$ \\
\hline Furt Collins, Co & 1 & $c(O C)$ & 531 & $\mathrm{Dry} / \mathrm{PH}$ & 1981 & 1406 \\
\hline Plorence, co & 3 & $C(G)$ & 1070 & $\begin{array}{l}\text { Wet } \\
\text { Wet } \\
\text { Wet }\end{array}$ & $\begin{array}{l}1948 \\
1948 \\
1974\end{array}$ & $\begin{array}{r}540 \\
540 \\
1503 \\
2583\end{array}$ \\
\hline Margan, Ut' & 2 & $\mathrm{C}(\mathrm{G})$ & 336 & $\begin{array}{l}\text { Wet } \\
\text { Wet }\end{array}$ & $\begin{array}{l}1948 \\
1948\end{array}$ & $\begin{array}{r}501 \\
501 \\
1002\end{array}$ \\
\hline lliree fiorks, M' & 1 & $C(G)$ & 360 & Wet & 1973 & 941 \\
\hline Seatie, WA & 1 & $c(0 \mathrm{C})$ & 700 & Wel: & 1967 & 1327 \\
\hline TOTAL COMPANY & 17 & & 7596 & & & 16,655 \\
\hline
\end{tabular}




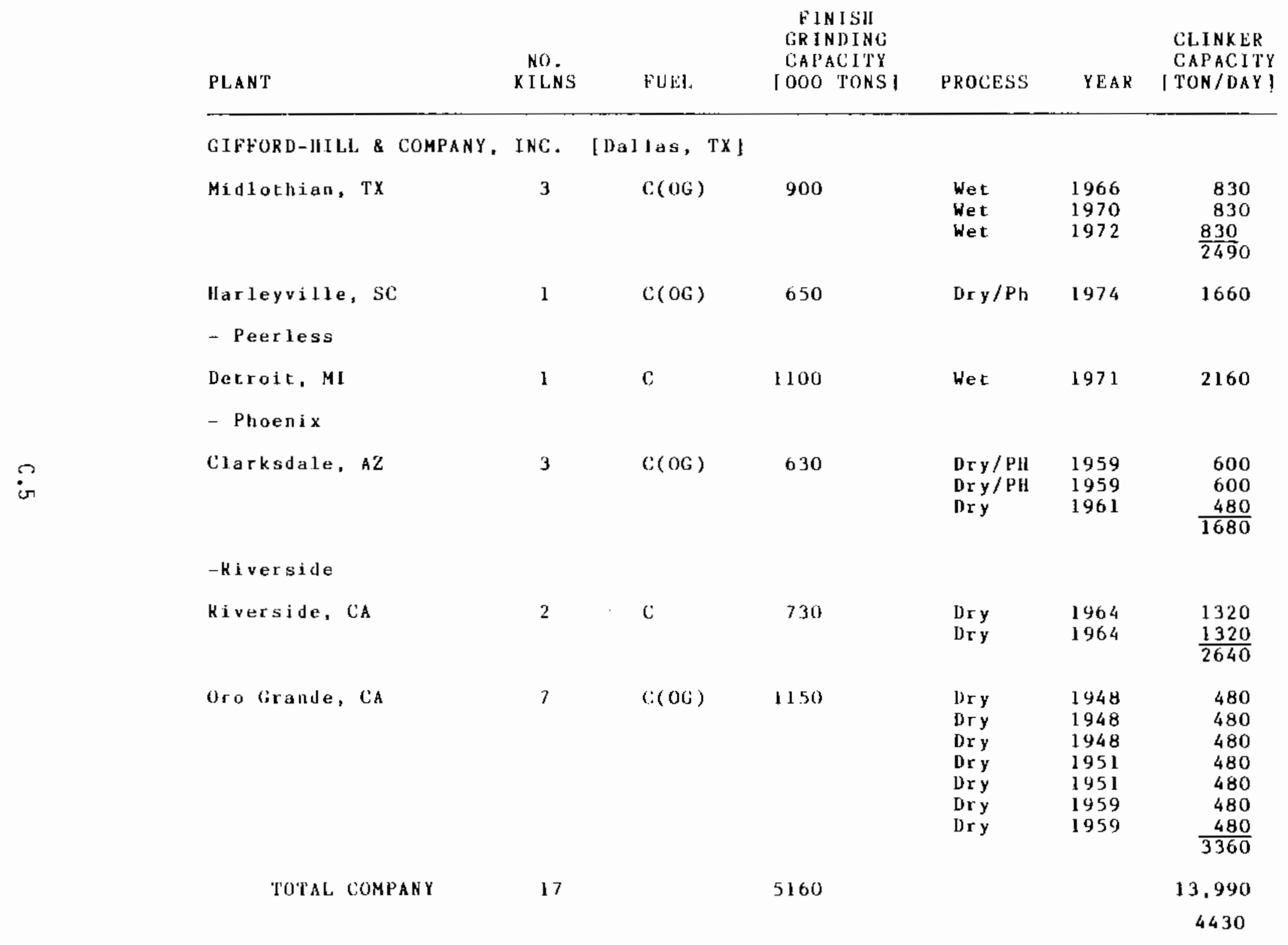




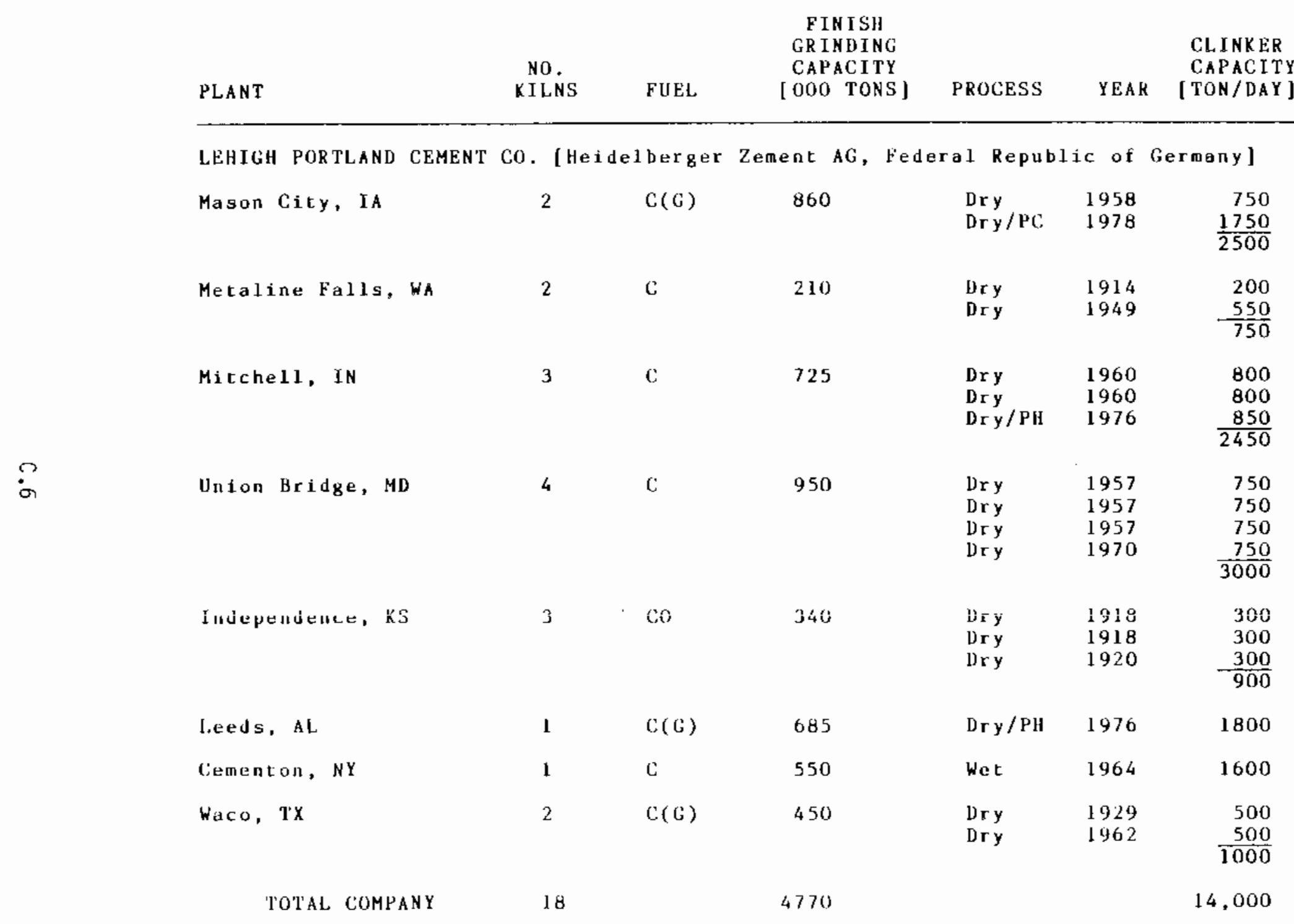




\begin{tabular}{|c|c|c|c|c|c|c|}
\hline PLANT & $\begin{array}{l}\text { NO. } \\
\text { KILNS }\end{array}$ & FUEL & $\begin{array}{c}\text { FINISH } \\
\text { GRINDING } \\
\text { CAPACITY } \\
{[000 \text { TONS] }}\end{array}$ & PROCESS & YEAR & $\begin{array}{l}\text { CLINKER } \\
\text { CAPACITY } \\
\text { [TON/DAY] }\end{array}$ \\
\hline \multicolumn{7}{|c|}{ KAISER CEMENT CORP. \{0akland, CA $\}$} \\
\hline Permanente, $\mathrm{CA}$ & 1 & $C(G)$ & 1600 & $\mathrm{Dry} / \mathrm{PC}$ & 1981 & 5000 \\
\hline Lucerne Valley, CA & 1 & $C(G)$ & 1600 & $\mathrm{Dry} / \mathrm{PC}$ & 1982 & 5000 \\
\hline San Antonio, TX & 1 & $C(G)$ & 490 & $\mathrm{Dry} / \mathrm{PC}$ & 1979 & 2500 \\
\hline Montana City, MT & 1 & $C(G)$ & 320 & Wet & 1963 & 950 \\
\hline Nanakuli, HI & 1 & $\mathrm{c}(0)$ & 320 & Wet & 1960 & 950 \\
\hline TO'SAL COMPANY & 5 & & 4330 & & & 14,400 \\
\hline
\end{tabular}

SOUTHWESTERN PORTLAND CEMENT CO. [Southdown, Inc., Houston, TX]

\begin{tabular}{|c|c|c|c|c|c|c|}
\hline Victorville, Ca & 2 & $\mathrm{C}(\mathrm{OG})$ & 1190 & $\begin{array}{l}\text { Dry } \\
\text { Dry/PH }\end{array}$ & $\begin{array}{l}1965 \\
1984\end{array}$ & $\begin{array}{r}1850 \\
2580 \\
\end{array}$ \\
\hline Fairborn, $O H$ & 2 & $c(0)$ & 737 & $\begin{array}{l}\text { Wet } \\
\text { Dry/Pil }\end{array}$ & $\begin{array}{l}1955 \\
1974\end{array}$ & $\begin{array}{r}400 \\
1835 \\
2235\end{array}$ \\
\hline El Paso, TX & 4 & $G(0)$ & 366 & $\begin{array}{l}\text { Dry } \\
\text { Dry } \\
\text { Dry } \\
\text { Dry }\end{array}$ & $\begin{array}{l}1910 \\
1910 \\
1917 \\
1950\end{array}$ & $\begin{array}{l}194 \\
194 \\
194 \\
219 \\
801\end{array}$ \\
\hline Odessa, TX & 2 & $c(i)$ & 529 & $\begin{array}{l}\text { Dry } \\
\text { Dry } / \text { PH }\end{array}$ & $\begin{array}{l}1958 \\
1978\end{array}$ & $\begin{array}{r}800 \\
900 \\
1700\end{array}$ \\
\hline Amarill 10, T'X & 1 & $c(G)$ & 305 & Wet & 1963 & 740 \\
\hline Lyons, co & 1 & $c(G)$ & 740 & $\mathrm{Dry} / \mathrm{PC}$ & 1980 & 1400 \\
\hline Leamington, UT & 1 & $c(0)$ & 725 & Dry $/$ PC & 1981 & 1800 \\
\hline TOTAL COMPANY & 13 & & 4592 & & & 13,106 \\
\hline
\end{tabular}




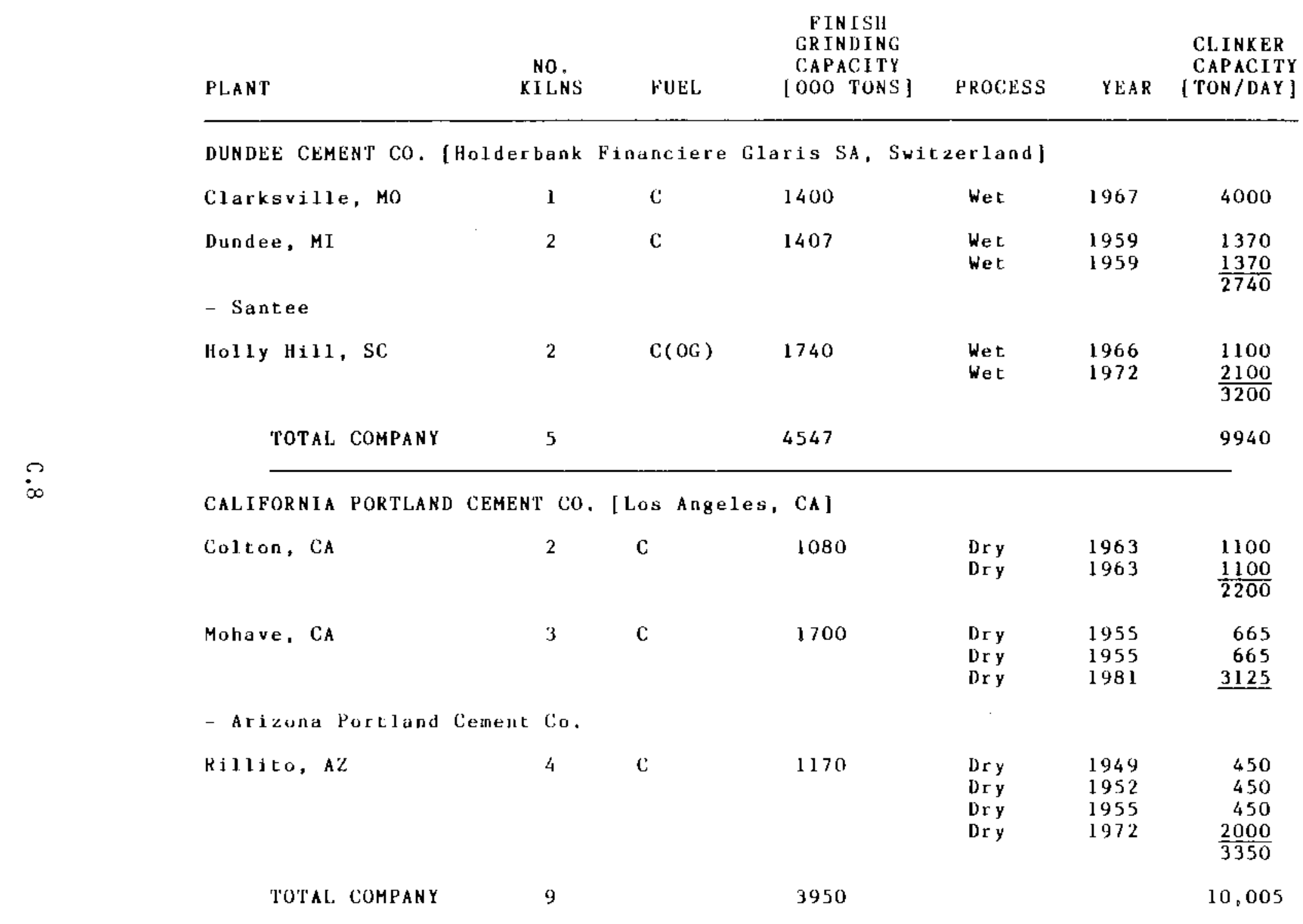




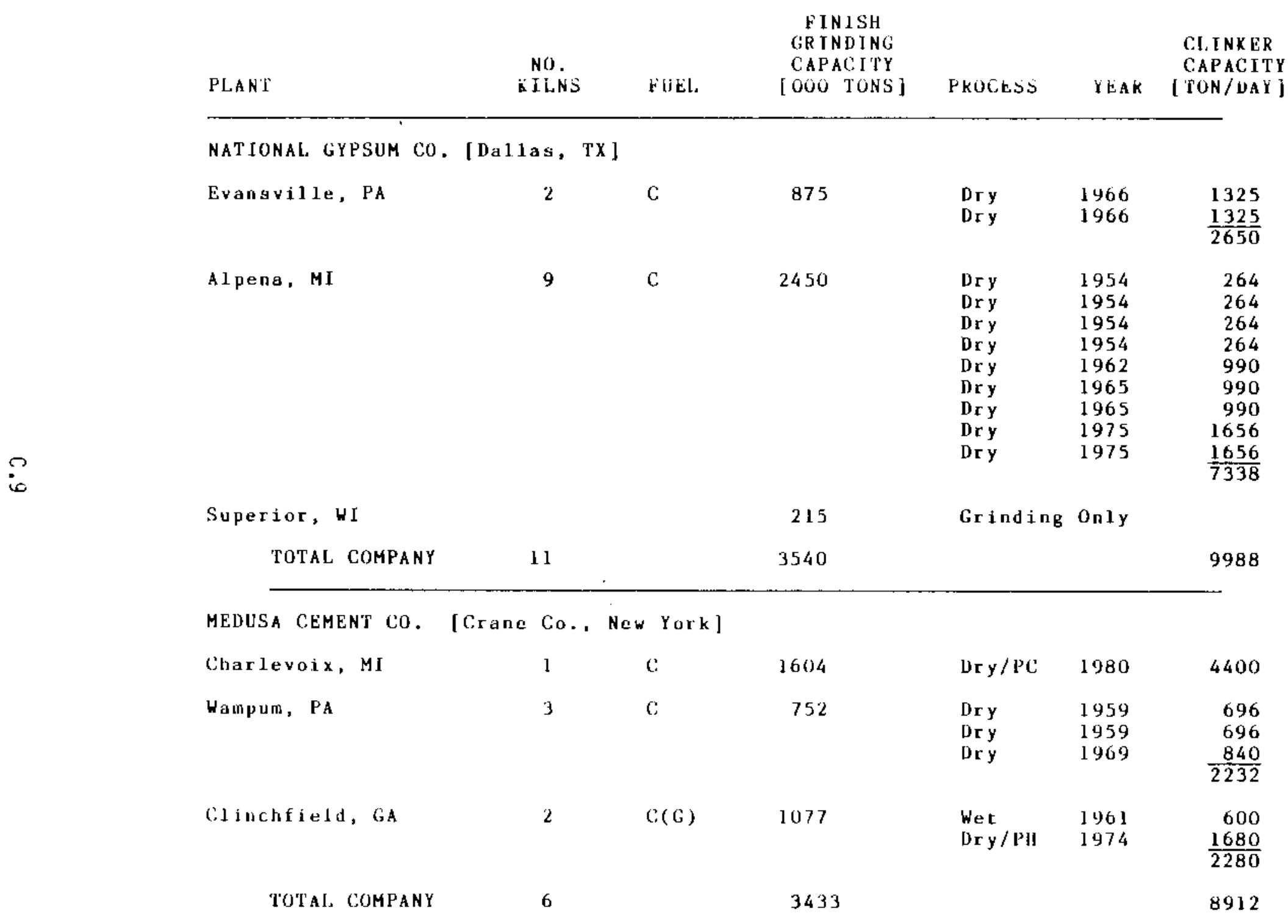




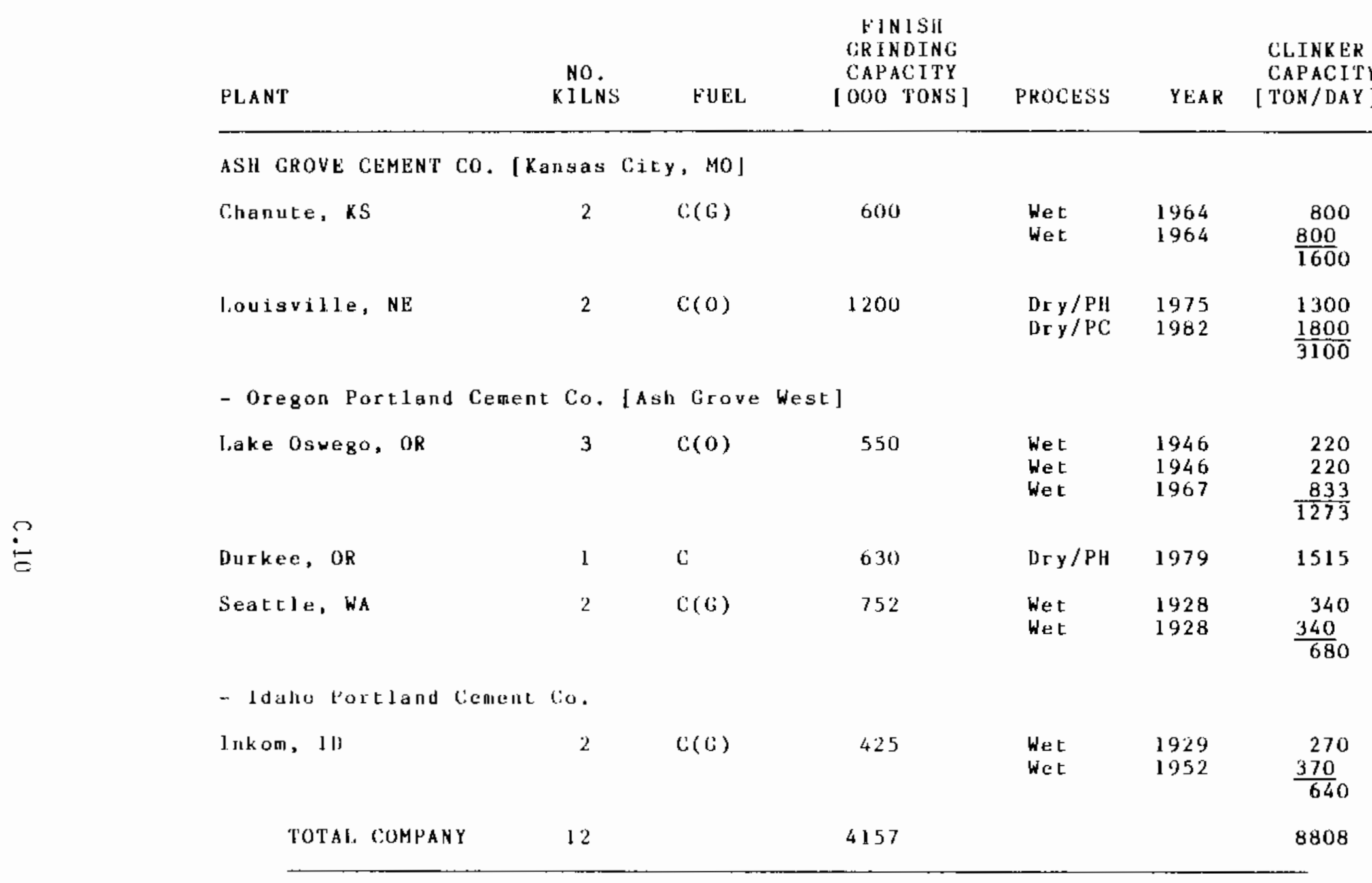

MOORE MCCORMaCk Cement InC. [Moore McCormack Resources, Inc., Stamford, CT ]

- Florida Mining and Materials

\begin{tabular}{|c|c|c|c|c|}
\hline ooksville, flu & 2 & $c(0)$ & 1356 & $\begin{array}{l}\mathrm{Dry} / \mathrm{PH} \\
\mathrm{Dry} / \mathrm{PH}\end{array}$ \\
\hline
\end{tabular}




\begin{tabular}{|c|c|c|c|c|c|c|}
\hline PI.ANI & $\begin{array}{l}\text { NO } \\
\text { KILNS }\end{array}$ & FUEL & $\begin{array}{c}\text { FINISH } \\
\text { GRINDING } \\
\text { CAPACITY } \\
\text { [00O TONS }]\end{array}$ & PROCESS & YEAR & $\begin{array}{l}\text { CLINKER } \\
\text { CAPACITY } \\
\text { [TON/DAY }\end{array}$ \\
\hline
\end{tabular}

[MOORE MCCORMACK, CONTINUED]

- Glen falls Portand Cement Co.

Glen Falls, NY

$1 \quad c(G)$

385

Dry/PH 1972

1750

Howes Cave, NY

180

Grinding 0nly

- Kosmos Cement Co.

Louisville, KY

1

C

800

Dry/PH 1974

2020

- Dixie Cement Co.

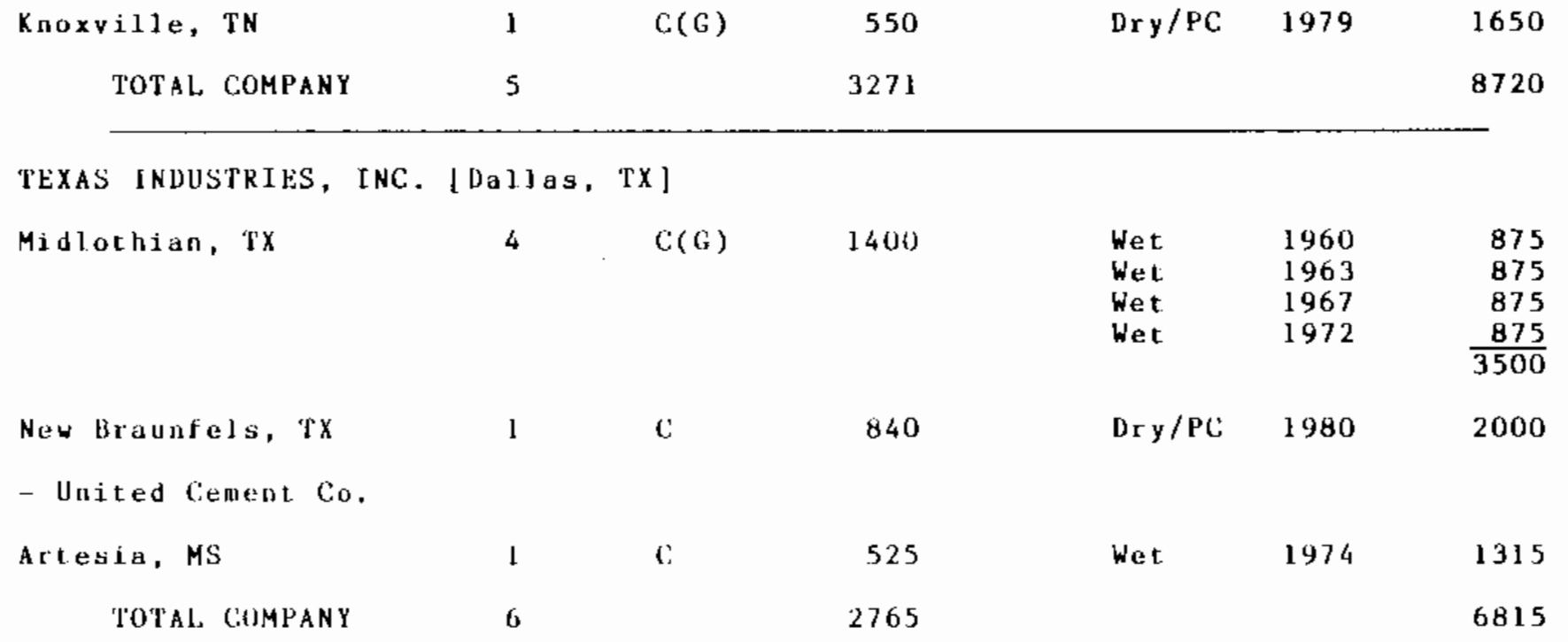


IIN ISH

NO. GRINDING
CAPACITY

OOO TONS

CLINKER

CAPACITY

PLAN'

KILNS

FIIEI

PROCESS

YEAR [TON/DAY]

CENTEX CORP. [ DaI]AS TX]

- Centex Cement

Corpus Christi, TX

2

C (G)

389

$\begin{array}{lll}\text { Wet } & 1950 & 420 \\ \text { Wet } & 1950 & 420 \\ & & \end{array}$

- Nevada Cement

Fernley, NV

2

$C(G)$

539

\begin{tabular}{llr} 
Dry & 1964 & 600 \\
Dry & 1969 & 600 \\
\cline { 3 - 3 } & &
\end{tabular}

- Illinois Cement

\begin{abstract}
La Salle, IL.
\end{abstract}
- Texas Cement

Buda, TX

TOTAL COMPANY
$1 \quad C(6)$

376

I

$C(G)$

2604

1974

1300

BLUE CIRCLE INC. [ Blue Circle Ludustries PLC, England]

Atlanta, GA

560

D) $\mathbf{r}$

Dr $\mathbf{r}$

$1961 \quad 900$

Dry/PC $\quad 1978$

3280

6620

Cia lera, A t

i

Tulsa, ok

2

c

670

Dr

1975

1975

900

$\frac{900}{1800}$

600

D) ry 1961

J) ry 1963

923

923

i 830 


\begin{tabular}{|c|c|c|c|c|c|c|}
\hline PLANT & $\begin{array}{l}\text { NO } \\
\text { KILNS }\end{array}$ & fUULl. & $\begin{array}{c}\text { FINISH } \\
\text { GRINDING } \\
\text { CAPACITY } \\
\text { [OOOTONS }\end{array}$ & PROCESS & YEAK & $\begin{array}{l}\text { CLINKEK } \\
\text { CAPACITY } \\
\text { |TON/DAY| }\end{array}$ \\
\hline
\end{tabular}

missouri portland cement co. [H.K. Forter Co., Inc., Pitesburgh, Pa]

\begin{tabular}{|c|c|c|c|c|c|}
\hline Sugar Creek, MO & 2 & $C(G)$ & 750 & $\begin{array}{l}\text { Dry } \\
\text { Dry }\end{array}$ & $\begin{array}{l}1954 \\
1957\end{array}$ \\
\hline Joppa, IL & 2 & $\mathrm{C}$ & 1550 & $\begin{array}{l}\text { Dry } \\
\text { Dry /PIf }\end{array}$ & $\begin{array}{l}1963 \\
1975\end{array}$ \\
\hline
\end{tabular}

TOTAL COMPANY

4

2300

5100

ATLANTIC CEMENT Co. [Newmont Mining Corp., New York]

Ravena, NY

2

C

2050

$\begin{array}{lll}\text { Wet } & 1962 & 2400 \\ \text { Wet } & 1962 & 2400\end{array}$

LOUISVILLE CEMENT CO. [ LoU ISVIIle, KY]

\begin{tabular}{|c|c|c|c|c|c|c|}
\hline Logansport, IN & 2 & $c(G)$ & 465 & $\begin{array}{l}\text { Wet } \\
\text { Wet }\end{array}$ & $\begin{array}{l}1962 \\
1966\end{array}$ & $\begin{array}{r}720 \\
720 \\
1440\end{array}$ \\
\hline Speed, IN & 2 & $c(c)$ & 1150 & $\begin{array}{l}\text { Dry } \\
\text { Dry / PII }\end{array}$ & $\begin{array}{l}1973 \\
1977\end{array}$ & $\begin{array}{l}1100 \\
2000 \\
\end{array}$ \\
\hline TO'OAL, COMI'ANY & 4 & & 1615 & & & 4540 \\
\hline
\end{tabular}

Coplay cement co. [Societe des ciments Francais, France]

$\begin{array}{lllllll}\text { Nazarelh, PA } & \text { l } & \text { C } & 1104 & \text { Dry/Pll } & 1978 & 3350\end{array}$




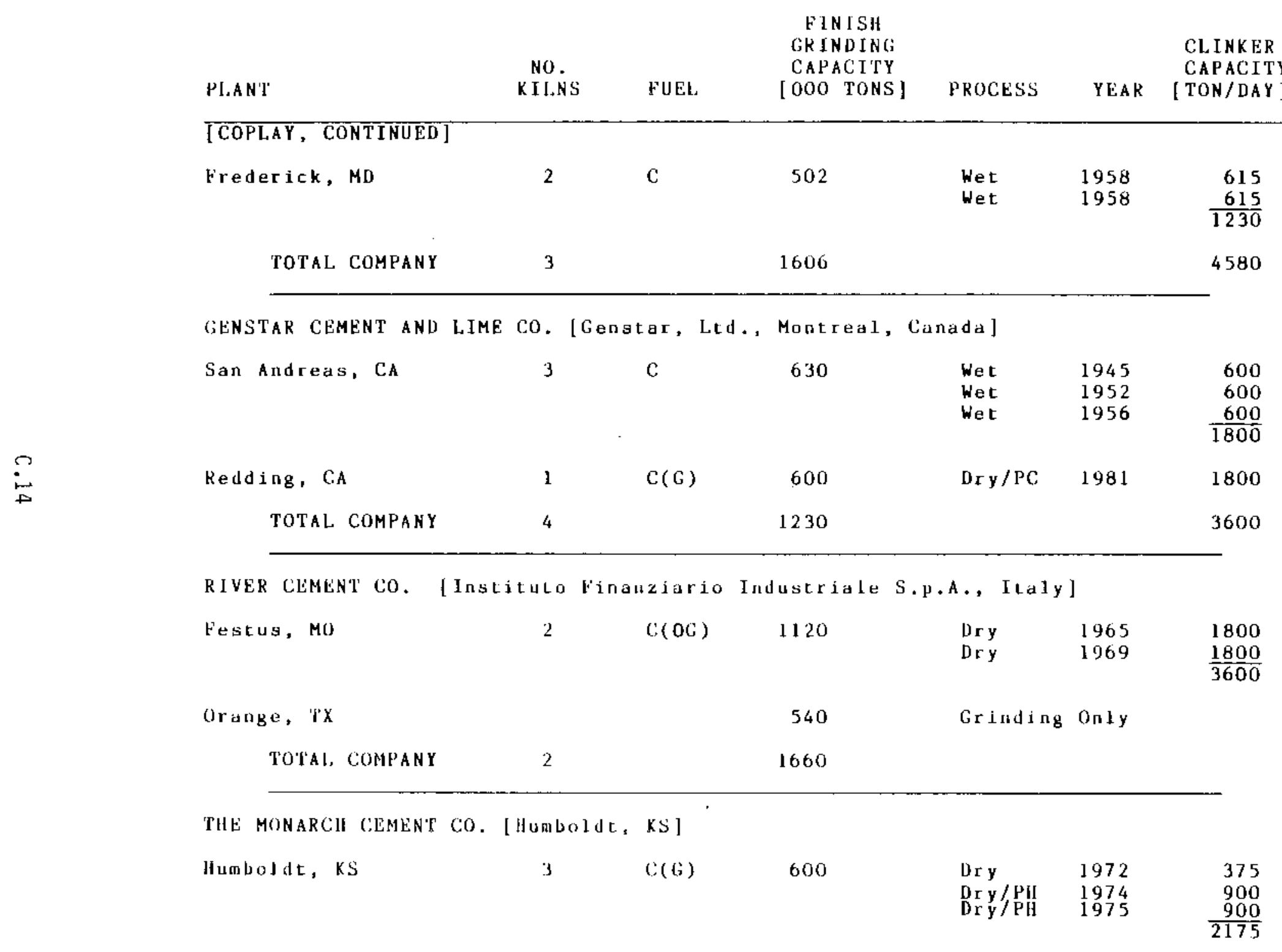




\begin{tabular}{|c|c|c|c|c|c|c|}
\hline PLANT & $\begin{array}{l}\text { NO } \\
\text { KILNS }\end{array}$ & FUEL & $\begin{array}{c}\text { FINISH } \\
\text { GRINDING } \\
\text { CAFACITY } \\
\text { [000 TONS] }\end{array}$ & PROCESS & YEAR & $\begin{array}{l}\text { CLINKER } \\
\text { CAPACITY } \\
\text { [TON/DAY] }\end{array}$ \\
\hline \multicolumn{7}{|l|}{ [MONARCH, CONTINUED] } \\
\hline Des Molnes, IA & 2 & $D(G)$ & 300 & $\begin{array}{l}\text { Wet } \\
\text { Wet }\end{array}$ & $\begin{array}{l}1951 \\
1941\end{array}$ & $\begin{array}{r}650 \\
500 \\
1150\end{array}$ \\
\hline TOTAL COMPANY & 5 & & 900 & & & 3325 \\
\hline
\end{tabular}

SME CEMENT INC. [Standard Machine and Equipment Co., Uniontown, PA]

\begin{tabular}{|c|c|c|c|c|c|c|}
\hline Middle Branch, OH & 1 & $C(G)$ & 400 & Dry/PH & 1958 & 650 \\
\hline Sylvania, OH & 3 & C & 360 & $\begin{array}{l}\text { Dry } \\
\text { Dry } \\
\text { Dry }\end{array}$ & $\begin{array}{l}1923 \\
1923 \\
1923\end{array}$ & $\begin{array}{l}250 \\
250 \\
250 \\
750\end{array}$ \\
\hline Bessemer, PA & 2 & $\mathrm{c}$ & 1000 & $\begin{array}{l}\text { Wet } \\
\text { Wet }\end{array}$ & $\begin{array}{l}1964 \\
1967\end{array}$ & $\begin{array}{r}1200 \\
800 \\
2000\end{array}$ \\
\hline TOYAL, COMPANY & 6 & & 1760 & & & 3400 \\
\hline
\end{tabular}

MONOLITH PORTLAND CEMENT CO. [Glendale, CA]

Laramie, WY

$\mathrm{C}(0)$

540

Wet $\quad 1961 \quad 540$

Wet $\quad 1981 \quad \frac{900}{1150}$

Monolith, CA

C

500

Wet

1974

1425

TOLAL. COMPANY

3

1040

2865 
F IN ISH

GRINDING

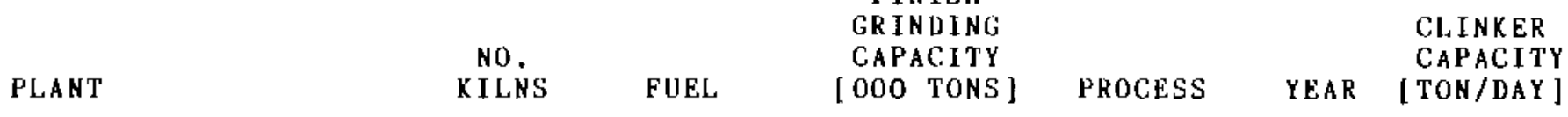

THE SOUTH DAKOTA CEMENT PLANT [Stace of South Dakota]

Kapid City, SD

$4 \quad \mathrm{C}(\mathrm{OG})$

1843

$\begin{array}{llr}\text { Wet } & 1951 & 500 \\ \text { Wet } & 1955 & 500 \\ \text { Wet } & 1957 & 500 \\ \text { Dry/PH } & 1978 & 1650 \\ & & \end{array}$

COLUMBIA CEMENT Co. [Ashland 0il, New York]

\begin{tabular}{|c|c|c|c|c|c|c|}
\hline Zanesville, OH & 2 & $\mathrm{C}$ & 600 & $\begin{array}{l}\text { Wet } \\
\text { Wet }\end{array}$ & $\begin{array}{l}1956 \\
1963\end{array}$ & $\begin{array}{r}750 \\
1100 \\
1850\end{array}$ \\
\hline Bellingham, WA & 2 & $\mathrm{C}$ & 400 & $\begin{array}{l}\text { Wet } \\
\text { Wet }\end{array}$ & $\begin{array}{l}1947 \\
1957\end{array}$ & $\begin{array}{r}541 \\
505 \\
1046\end{array}$ \\
\hline TOTAL COMPANY & 4 & & 1000 & & & 2896 \\
\hline
\end{tabular}

NORTHWESERN STATES PORTLAND CEMENi CO, [Mason City, la]

Mason City, IA

3

C. (G)

1150

$\begin{array}{llr}\text { Dry } & 1960 & 500 \\ \text { Dry } & 1966 & 1500 \\ \text { Dry } & 1976 & 800 \\ & & 2800\end{array}$

ARKANSAS CEMEN'J CORP. [Arkallas l.ouisiana Gas Co., Shreveport, l.A ]

Foremall, AR

3

$C(G)$

1020

$\begin{array}{ll}\text { Wet } & 1958 \\ \text { Wet } & 1963 \\ \text { Wet } & 1967\end{array}$




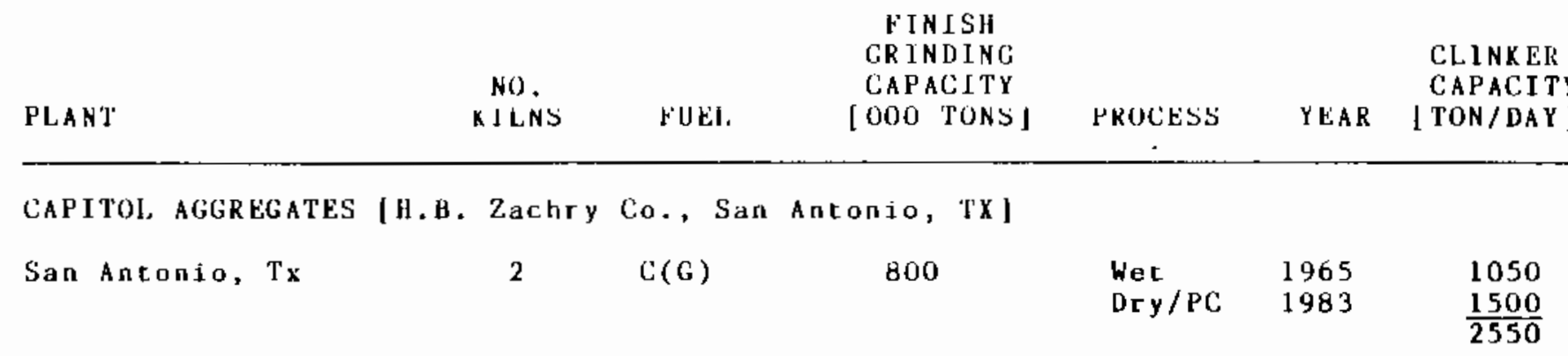

CAPITOL CEMENT [Rivertón Corp.. Riverton, VA]

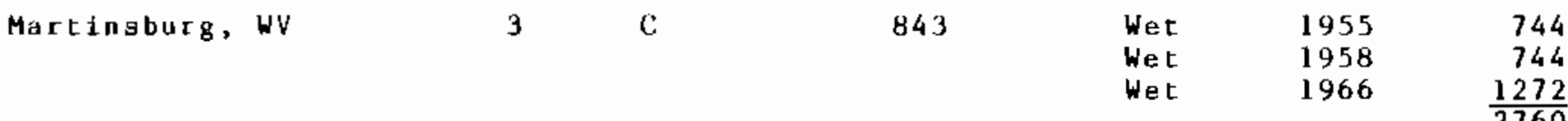

GIAN'T PORTLAND AND MaSOnRY CEMENT' CO. [COlumbia, SC]

$\begin{array}{llllrr}\text { Harleyville, SC } & \text { C (G) } & 950 & \text { Wet } & 1952 & 650 \\ & & & \text { Wet } & 1956 & 650 \\ & & \text { Wet } & 1960 & 650 \\ & & \text { Wet } & 1972 & \frac{650}{2600}\end{array}$

NATIONAL CEMENT CO. [SOciete Anonyme des Ciments Vicat, France]

$\begin{array}{lllllll}\text { Kagland, Al, } & 1 & C(O G) & 900 & \text { Dry/PC } & 1976 & 2400\end{array}$

DAVISNOR' CLMENT [Cesnentia Hoddiags, A.G., Switzerland]

Davenporl, lA

1

850

Dry/PC 1981

2600

Alamo CEMent Co. IPresa S.P.A. Cementeria Kobilante, Ilaly ]
San Antonio, TX
1
$c(\mathrm{G})$
600
Dry $/$ PC 1981
2400 


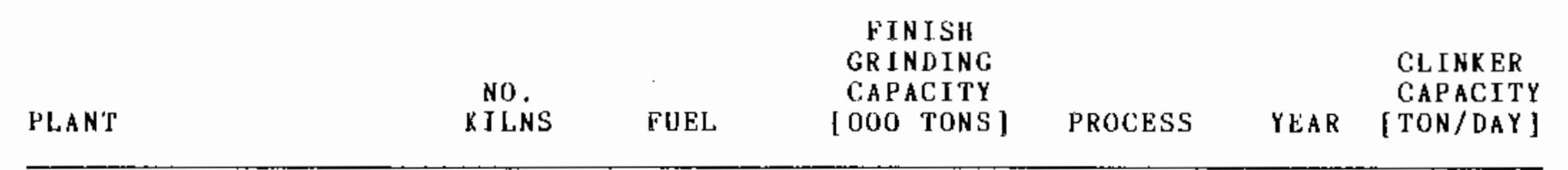

COnTINENTAL CEment Co. [Cementa AB, Switzerland]

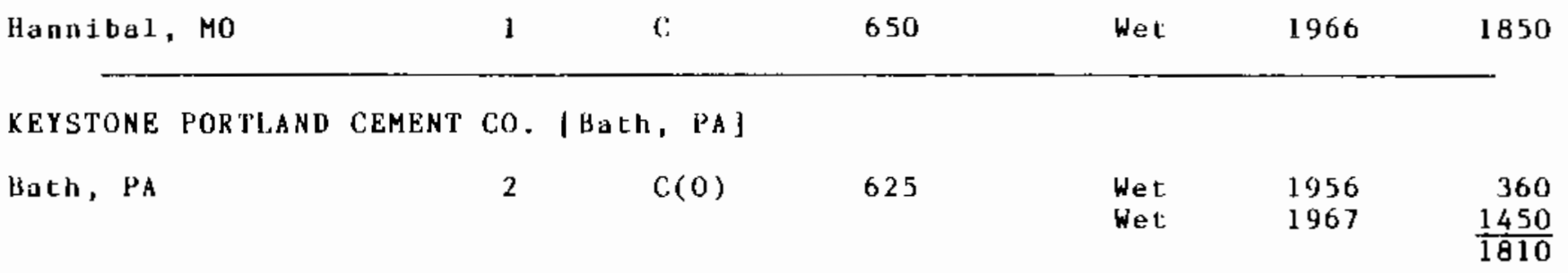

\section{INDEPENDENT CEMENT}

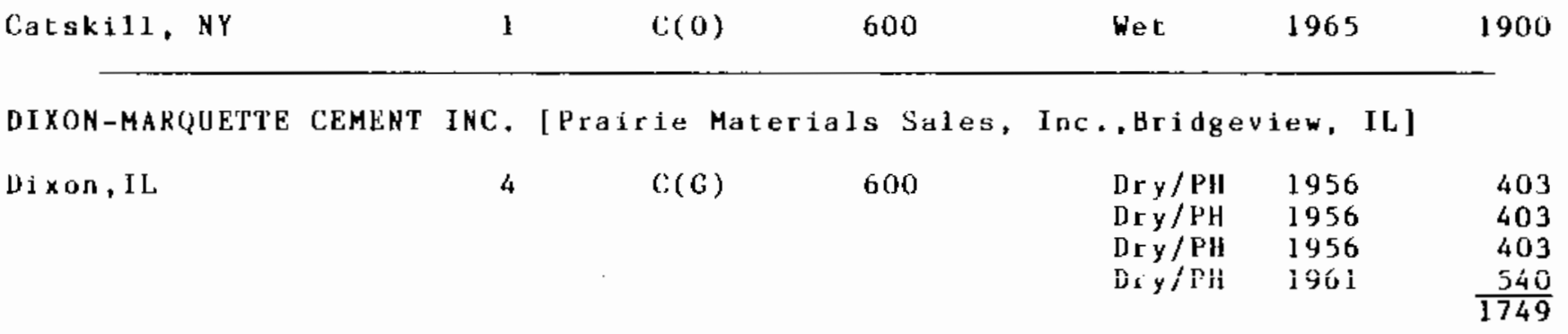

RINKER POR'llani Cement CORP. [Riaker Materials Corp., West Palm Beach, FL]

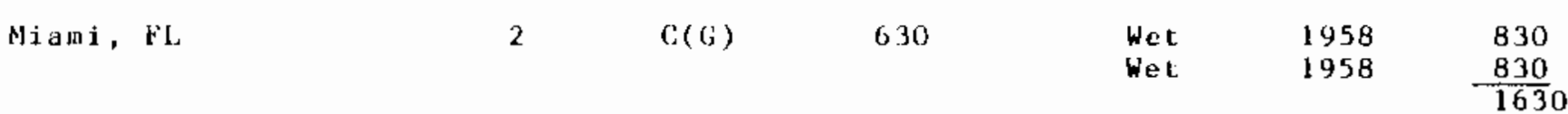

HERCULES CEMEN' Co. [Instituto finanziario Industriale S.P.A., Italy]

Stockerton, PA

is

c

745

$\begin{array}{llr}\text { Dry } & 1955 & 530 \\ \text { Dry } & 1955 & 530 \\ \text { Dry/PH } & 1975 & 820 \\ & & \text { T880 }\end{array}$




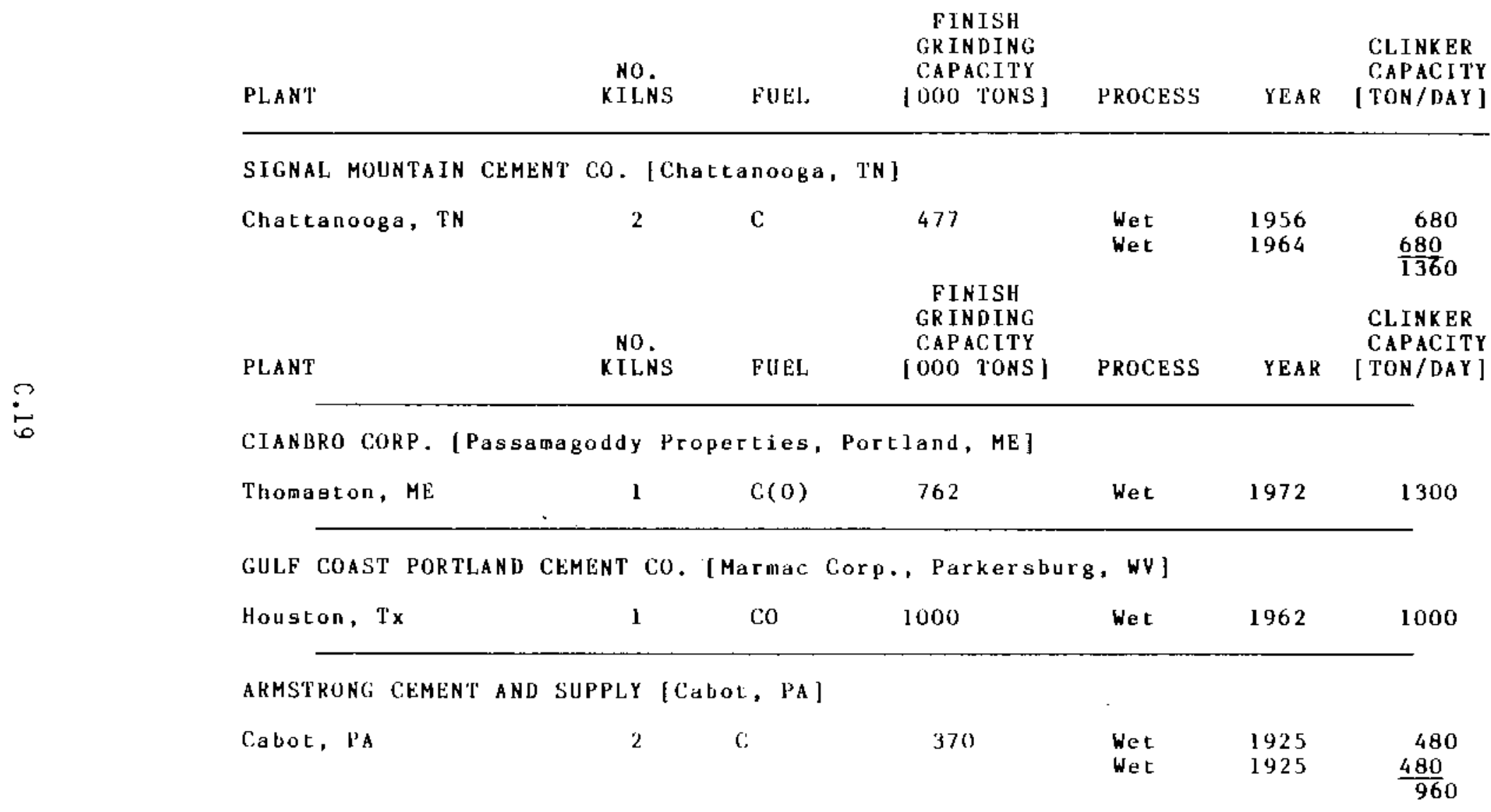


GRINDING ONLY FACILITIES:

\begin{tabular}{|c|c|c|c|c|c|c|}
\hline PLANT & $\begin{array}{l}\text { NO. } \\
\text { KILNS }\end{array}$ & FUEL & $\begin{array}{c}\text { FINISH } \\
\text { GRINDING } \\
\text { CAPACITY } \\
\text { OOO TONS }\end{array}$ & PROCESS & YEAR & $\begin{array}{l}\text { CLINXER } \\
\text { CAPACITY } \\
\text { TON / DAY }\end{array}$ \\
\hline & & FUEL & & & DEAK & \\
\hline
\end{tabular}

abena CEmEnT CoRP. [Lake Ontario Cenent Co., Ioronto, Canada]

$\begin{array}{ll}\text { Essexville, MI } & 600\end{array}$

ALASKA BASIC INDUSTRIES [Anchorage, Ak]

$\begin{array}{ll}\text { Anchorage, AK } & 75\end{array}$

National PORTLAND CEMENT CO. OF FLORIDA, INC. [Palmetto, FL]

Port Manatee, FL

350

ST. MARYS CEMENT LTD. [Toronto, Canada]

- St. Mary's Wyandotte

Wyandotce, MI

288

- St. Mary's Wisconsin

Milwakee, Wl

120

'I'OT'AL COMPANY 
APPENDIX D

ENERGY-SAVINGS METHODOLOGY 
APPENDIX D

\section{ENERGY-SAVINGS METHODOLOGY}

The assumptions made and the method used to calculate the energy-savings potential of the current and advanced technologies are discussed below. A sample calculation is provided to illustrate the methodology.

The energy-savings calculations involved the following steps:

1. establish a baseline energy use

2. determine energy use of energy-conserving technology

3. determine technical market for technology in terms of units of production

4. calculate energy savings.

BASEL INE ENERGY USE

The baseline energy profile is presented in Chapter 2. This energy profile is based on 1982 production and energy-use figures reported by the Portland Cement Association and the U.S. Bureau of Mines. Some of the statistics relevant to the energy-savings calculations are as follows:

Total 1982 energy use: 298,235 billion Btu di rect energy use 356,588 billion Btu indirect energy use

1982 Ave. Usage Wet Process: $6.1 \times 10^{6} \mathrm{Btu} /$ ton cement

1982 tve. Usage Long-Dry Process: $5.6 \times 10^{6} \mathrm{Btu} / \mathrm{ton}$ cement

1982 Ave. Preheater Process: $4.4 \times 10^{6}$ Btu/ton cement

1982 Ave. Usage Precalciner Process: $4.2 \times 10^{6}$ Btu/ton cement

19:32 Ave. Usage A11 Processes: $4.889 \times 10^{6} \mathrm{Btu} /$ ton cement

$1982 \mathrm{Clinker}$ Production: $60.254 \times 10^{6}$ tons

1982 Cement Production: $63.355 \times 10^{6}$ tons 
DETERMINE ENERGY USE OF ENERGY-CONSERVING TECHNOLOGY

The energy use of a technology was determined by first collecting energyuse values from the literature or by obtaining information from manufacturers/vendors. These values were typically reported as energy use in Btu/ton clinker or per ton of cement, energy savings in Btu/ton cement or per ton of clinker, or energy savings as a percentage of current energy use. These figures were all converted to Btu/ton of cement using the 1982 production information. These figures are reported in Column 1 of Table S.1.

DETERMINE TECHNICAL MARKET

The technical market was determined by analyzing the current level of deployment of a given technology and by examining the remaining opportunities for deployment. For example, 58.2\% of 1982 capacity used the dry process. Thus, the technical market for wet to dry conversion is $41.8 \%$ or $25.2 \times 10^{6}$ tons clinker. No attempt was made to determine the rate of market penetration. In some cases, the current Tevel of deployment of a given technology was not available (e.g., the use of roller mills for raw material preparation). In these cases, an attempt was made to make conservative estimates to avoid overstating potential energy savings. In the case of the roller mills, it was assumed that all dry capacity installed since 1976 employs roller mills for raw grinding.

\section{CALCULATE ENERGY SAVINGS}

Annual energy savings are calculated by multiplying the difference in unit energy use between existing technology and the energy-conserving technology by the technical market size. The annual energy savings are divided by the 1982 energy use to determine the savings as a percentage of 1982 use.

\section{SAMPLE CALCULATIDN}

The following energy-saving calculation for adopting preheaters is included to illustrate the steps outlined above. 
Step 1: Baseline Energy Usage (Roy 1983):

- 1982 industry total - 298,235 billion Btu

- 1982 wet process $-6.1 \times 10^{6}$ Btu/ton cement

- 1982 long-dry process $-5.6 \times 10^{6} \mathrm{Btu} /$ ton cement

Step 2: Determine Energy Use of Preheater:

- Average energy use of preheater process in U.S. $-4.4 \times 10^{6}$ Btu/ton cement (Roy 1983)

Note: This figure will lead to a conservative estimate of the energy-savings pistential since it is based on industry averages, not on best-available technology.

Step 3: Determine Technical Market:

The wet process accounts for $39.6 \%$ of production capacity, and the longdry process accounts for $21.7 \%$ of capacity for a total technical market of $61.3 \%$ of total capacity or 38.837 million tons.

Step 4: Calculate Energy Savings:

- Relative to wet process -

$\left[6.1 \times 10^{6}\right.$ Btu/ton $]-\left[4.4 \times 10^{6}\right.$ Btu/ton $]=1.7 \times 10^{6}$ Btu/ton

- Relative to long-dry process-

$\left[5.6 \times 10^{6} \mathrm{Btu} /\right.$ ton $]-\left[4.4 \times 10^{6} \mathrm{Btu} / \mathrm{ton}\right]=1.2 \times 10^{6} \mathrm{Btu} / \mathrm{ton}$

- Total annual savings -

$\left[1.7 \times 10^{6} \mathrm{Btu} /\right.$ ton $][0.396]\left[63.355 \times 10^{6}\right.$ tons $]=42.7 \times 10^{12} \mathrm{Btu}$

$\left[5.6 \times 10^{6} \mathrm{Btu} /\right.$ ton $][0.217]\left[63.355 \times 10^{6}\right.$ tons $]=16.5 \times 10^{12} \mathrm{Btu}$

TOTAL

$59.2 \times 10^{12} \mathrm{Btu}$

0.3 
- Percent of 1982 energy use -

$\left[59.2 \times 10^{12} \mathrm{Btu}\right] /\left[356.588 \times 10^{12} \mathrm{Btu}\right]=16.6 \%$

D. 4 


\section{DISTRIBUTION}

No. of

Copies

OFFSITE

Mr. John Rossmeiss 1

U.S. Department of Energy

Office of Industrial Programs

Forrestal Building

1000 Independence Ave., S.W.

Washington, D.C. 20585

Mr. Jerome Collins

U.S. Department of Energy

Office of Industrial Programs

Forrestal Building

$100 C$ Independence Ave., S.W.

Wast ington, D.C. 20585

$\mathrm{Mr}$. Ralph Sheneman

U.S. Department of Energy

Office of Industrtial Programs

Forrestal Building

$100 \mathrm{C}$ Independence Ave., S.W.

Wastington, D.C. 20585

30 DOE Technical Information

Center

Mr. Randy Bergman

Maintenance Supervisor

Ideal Basic Industries, Inc.

$540 C$ West Marginal Way, S.W.

Seattle, WA 98106

Dr. M. S. Y. Bhatty

Senior Research Chemist

Construction Technology Laboratories

Port land Cement Association

5420 0ld Orchard Road

Skokie, IL 60077

Mr. Thomas J. Brown

Depi rtment 4736

Allis-Chalmers Corporation

P.0. Box 512

Milwaukee, WI 53201
No. of

Copies

Mr. Richard Cooke

Plant Manager

Ash Grove Cement West, Inc.

Box 5

Durkee, OR 97905

Mr. Fred Currier

Chief Engineer

Sturtevant, Inc.

103 Clayton St.

Boston, MA 02122

Ms. Julie Dodds

EG\&G Idaho, Inc.

P.0. Box 1625

Idaho Falls, ID 83415

Mr. Gordon Fisher

Polysius Corporation

180 Interstate North

Atlanta, GA 30339

Mr. Bill Fleming

Gifford-Hill \& Company

P.0. Box 520

Midlothian, TX 76065

Mr. Ken Hitcho

Manager, Cement Group

Humboldt Wedag

3200 Pointe Parkway

Atlanta, GA 30092

Mr. Jim Ketcham

F. L. Smidth \& Company

300 Knickerbocker Road

Cresskill, NJ 07626

Mr. Bryant Mather

Chief, Structures Laboratory

Waterways Experiment Station

P.0. Box 631

Vicksburg, MS 39180 
No. of

Copies

Mr. A. W. Mees

Process Control Administrator Ideal Basic Industries

P.0. Box 8789

Denver, C0 80201

Mr. D. Raponi

President

Summa 1 Corporation

P.0. Box 15776

Panama City, FL 32406

Mr. S. W. Tresouthick, Director Chemical/Physical Research Department

Portland Cement Association

5420 0ld 0rchard Road

Skokie, IL 60077
No. of

Copies

ONSITE

DOE Richland Dperations Office

H. E. Ransom

38 Pacific Northwest Laboratory

C. H. Bloomster

T. D. Chikalla

J. W. Currie

L. L. Fassbender

B. A. Garrett-Price (20)

C. R. Hann

V. E. Lee

N. L. Moore

R. M. Fleischman

Econonics Library (3)

Publishing Coordination $\mathrm{MH}$ (2)

Technical Information (5) 